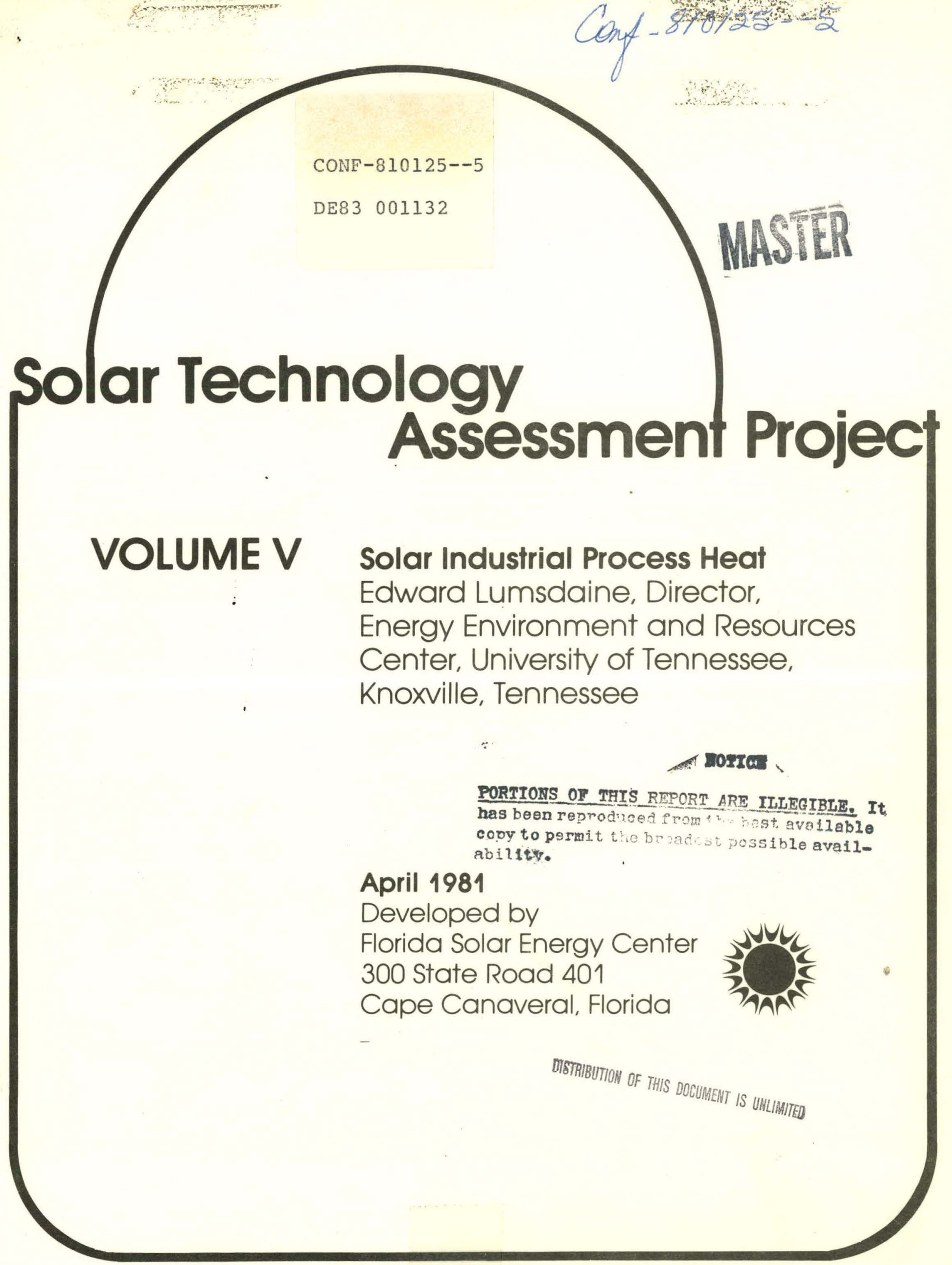




\section{DISCLAIMER}

This report was prepared as an account of work sponsored by an agency of the United States Government. Neither the United States Government nor any agency Thereof, nor any of their employees, makes any warranty, express or implied, or assumes any legal liability or responsibility for the accuracy, completeness, or usefulness of any information, apparatus, product, or process disclosed, or represents that its use would not infringe privately owned rights. Reference herein to any specific commercial product, process, or service by trade name, trademark, manufacturer, or otherwise does not necessarily constitute or imply its endorsement, recommendation, or favoring by the United States Government or any agency thereof. The views and opinions of authors expressed herein do not necessarily state or reflect those of the United States Government or any agency thereof. 


\section{DISCLAIMER}

Portions of this document may be illegible in electronic image products. Images are produced from the best available original document. 


\section{ACKNOWLEDGEMENTS}

I wish to extend special acknowledgements to the U.S. Department of Energy and, in particular, to Ms. Sheryl Zakaria for her guidance, and to Mr. Chuck Kezar for his assistance and to Dr. Thomas Stelson for the original idea and his assistance.

David L. Block, Director

Florida Solar Energy Center

\section{NOTICE}

This work was prepared as part of work sponsored by the U.S. Departmeni of Energy under the Cooperative Agreement DE-FC02-79CS3078-A001. The views and opinions of the authors expressed herein do not necessarily state or reflect those of the Florida Solar Energy Center, the United States Government or any agency thereof 


\section{PREFACE}

The purpose of the Solar Technology Assessment Project is to present an assessment of the state of solar energy technology for individuals involved in energy research, industry, legislation and policy, and to others interested in a better understanding of the nation's energy future.

This project was organized and coordinated by the Florida Solar Energy Center under sponsorship of the Office of Policy, Planning and Evaluation; Office of Conservation and Renewable Energy; U.S. Department of Energy; Cooperative Agreement DE-FC02-79CS30278-A001.

For this project, nine solar technologies--four solar thermal, four solar electric, and one other--were evaluated as follows:

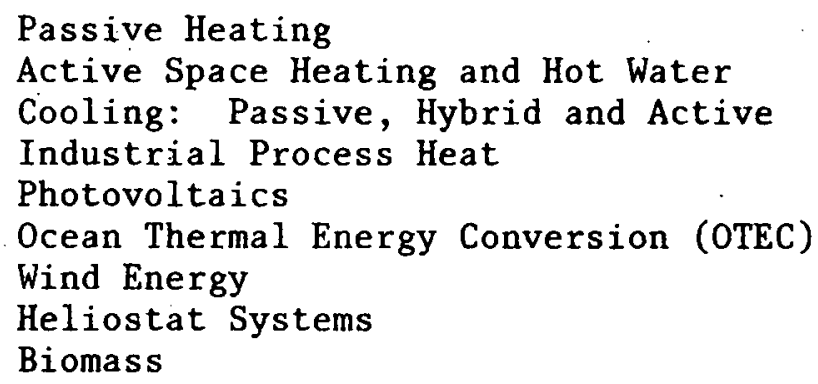

Finally, to complete the picture, two other assessments were done, one on the current status and prospects of the solar industry and the other on state and community solar commercialization issues.

The Solar Technology Assessment Project selected 11 recognized solar experts, each to assess and write a paper on the particular solar technology or area of his expertise. Summaries of the assessment papers by the group were presented at the Solar Technology Assessment Conference in Orlando, Florida, on January 29 and $30,1981$.

After the January conference, each of the authors wrote a final assessment paper. These papers are presented as 12 volumes, one for each assessment area and one overall review by the project director. The authors are listed on the next page.

As a final comment, it is hoped that these assessments will provide the information and possibly supply the guidance that is needed by the decision makers in order to bring the utilization of solar energy to the level where its positive impact will be felt by all.

This report was prepared as an account of work sponsored by an agency of the Untred Sultes Quvea unteall Neither the United States Government nor any agency thereof. not any of their employees, makes any warranty, express of implied, or assumes any legat liability or responsibility for the accuracy. completeness, or usefintness of anv information, apparazus, product, or process disclosed, or represents that its use would not intringe privately owned rights. Reterence herein to any specific commercial product. process. of service by trade nama, trademark, manufacturer, of otherwise, does not necessarily constive or imply is endirsmen,

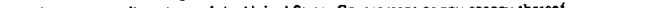

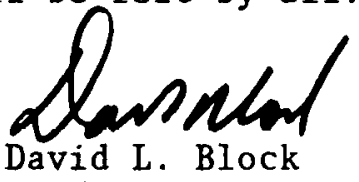

Project Director

Solar Technology Assessment Project and

Director

Florida Solar Energy Center 
THIS PAGE

\section{WAS INTENTIONALLY LEFT BLANK}




\section{SOLAR TECHNOLOGY ASSESSMENT PROJECT}

\section{List of Reports}

VOLUME I

VOLUME II

VOLUME III

VOLUME IV

VOLUME V

VOLUME VI

VOLUME VII

VOLUME VIII

VOLUME IX

VOLUME $X$

VOLUME XI

VOLUME XII
THE STATE OF SOLAR ENERGY TECHNOLOGY -- David L. Block, Florida Solar Energy Center, Cape Canaveral, Florida

PASSIVE SOLAR TECHNOLOGY -- Donald Watson, Architect and Visiting Professor, Yale University, New Haven, Connecticut

ACTIVE SPACE HEATING AND HOT WATER SUPPLY WITH SOLAR ENERGY -- S. Karaki and G.0.G. Löf, Solar Energy Applications Laboratory, Colorado State University, Fort Collins, Colorado

SOLAR AIR CONDITIONING - ACTIVE, HYBRID AND PASSIVE -John I. Yellott, College of Architecture, Arizona State University, Tempe, Arizona

SOLAR INDUSTRIAL PROCESS HEAT -- Edward Lumsdaine, Energy, Environment and Resources Center, University of Tennessee, Knoxville, Tennessee

PHOTOVOLTAIC TECHNOLOGY ASSESSMENT -- Charles E. Backus, Center for Research, Arizona State University, Phoenix, Arizona

A REVIEW OF OTEC -- Paul C. Yuen, Hawaii Natural Energy Institute, University of Hawaii, Honolulu, Hawaii

WIND ENERGY -- William L. Hughes, R.G. Ramakumar, and Dan D. Lingelbach, Engineering Energy Laboratory, Oklahoma State University, Stillwater, Oklahoma

HELIOSTAT SYSTEMS: TECHNIICAL AND ECONOMIC ASSESSMENT -A. F. Hildebrandt and C. L. Laurence, Energy Laboratory, University of Houston, Houston, Texas

SOLAR TECHNOLOGY ASSESSMENT: BIOMASS -- Albert P. Sheppard, Jerry L. Birchfield and Jack M. Spurlock, Georgia Institute of Technology, Atlanta, Georgia

THE SOLAR INDUSTRY IN THE UNITED STATES: ITS STATUS AND PROSPECTS - 1981 -- John A. Clark, Department of Mechanical Engineering and Applied Mechanics, University of Michigan, Ann Arbor, Michigan.

STATE AND COMMUNITY COMMERCIALIZATION ISSUES -- Ronald D. Doctor, Western Sun, Portland, Oregon and Janice Hamrin, Alliance for Renewable Energy, Sacramento, California 
THIS PAGE

\section{WAS INTENTIONALLY LEFT BLANK}


VOLUME V

\title{
SOLAR INDUSTRIAL PROCESS HEAT
}

\author{
by \\ Edward Lumsdaine \\ Energy, Environment and Resources Center \\ University of Tennessee \\ Knoxville, Tennessee
}

A very short time ago, Dr. Lumsdaine left his position as director of the New Mexico Solar Energy Institute to become director of the Energy, Environment and Resources Center and professor of mechanical and aerospace engineering at the University of Tennessee--a pretty good distance to move for most, but not for this much-travelled scientist. Dr. Lumsdaine has been a visiting professor to Cairo University in Egypt and Tatung Institute of Technology in Taipei, Republic of China. He spent two summers at JPL-California Institute of Technology. and did research at the NASA-Langley transonic compressor facility. He travelled to Costa Rica for the National Academy of Sciences, and he spent time in that country, Brazil and Colombia as a representative of the International Communications Agency of the U.S. State Department. Prior to heading the New Mexico solar center, Dr. Lumsdaine was a research engineer for the Boeing Company in Seattle, an assistant/associate professor at South Dakota State University and professor of mechanical engineering at the University of Tennessee. His work as principal investigator of 17 research grants has resulted in more than 70 publications in the fields of solar energy research, fluid mechanics, and aero acoustics and turbo machinery. He received the B.S. and M.S. degrees and doctorate from New Mexico. University. 
SOLAR INDUSTRIAL PROCESS HEAT (SIPH)

\author{
Edward Lumsdaine \\ Director \\ Energy, Environment, and Resources Center \\ The University of Tennessee \\ Knoxville, TN 37916
}

\title{
I. EXECUTIVE SUMMARY
}

\section{A. Introduction}

The aim of this Solar Industrial Process Heat (SIPH) assessment is to candidly assess the contribution SIPH is realistically able to make in the near and long term energy future of the United States. The performance history of government and privately funded SIPH demonstration projects and the present status of SIPH technology will be examined. Before making final recommendations, the influence of economic and sociopolitical factors (which have a very large effect on the acceptability and application of any new, alternate energy technology) will be considered also.

The industrial sector with 37 percent is the largest user of energy in the United States, followed by transportation with 26 percent, residential with 22 percent and commercial with 15 percent of a total of 78 quads (Q) in 1979 ( $1 \mathrm{Q}=10^{15} \mathrm{Btu}$ ). The U.S. Department of Energy (DOE) defines this sector to include agriculture, mining and petroleum extraction, contract construction, and manufacturing. However, in this report, energy use by agriculture will be discussed in a separate section. The industrial consumption data presented here will not include agriculture which constitutes about 4 percent of the industrial sector as defined by DOE. Manufacturing consumes by far the largest share with 84 percent, whereas mining uses 8 percent and construction 4 percent.

Total industrial energy consumption for 1978 broken down into primary source categories and the history of industrial energy consumption since 1948 are shown on Figure 1. Note that electric conversion losses attributable to purchased electricity by the industrial sector have been represented separately. This immediately points out one problem for industrial consumers: electricity cannot be indiscriminately substituted for petroleum-based fuels unless this electricity is either generated from coal or renewable resources, or cogeneration and cascading are employed. The cost of electricity can be expected to increase steadily, as petroleum and natural gas prices become deregulated and as the proportion of expensive newer plants increases in the electric generating pool. In 1978,14 percent of all the electricity generated nationwide came from natural gas, 16 percent from oil, about 14 percent from hydro, 


\section{FIGURE 1}

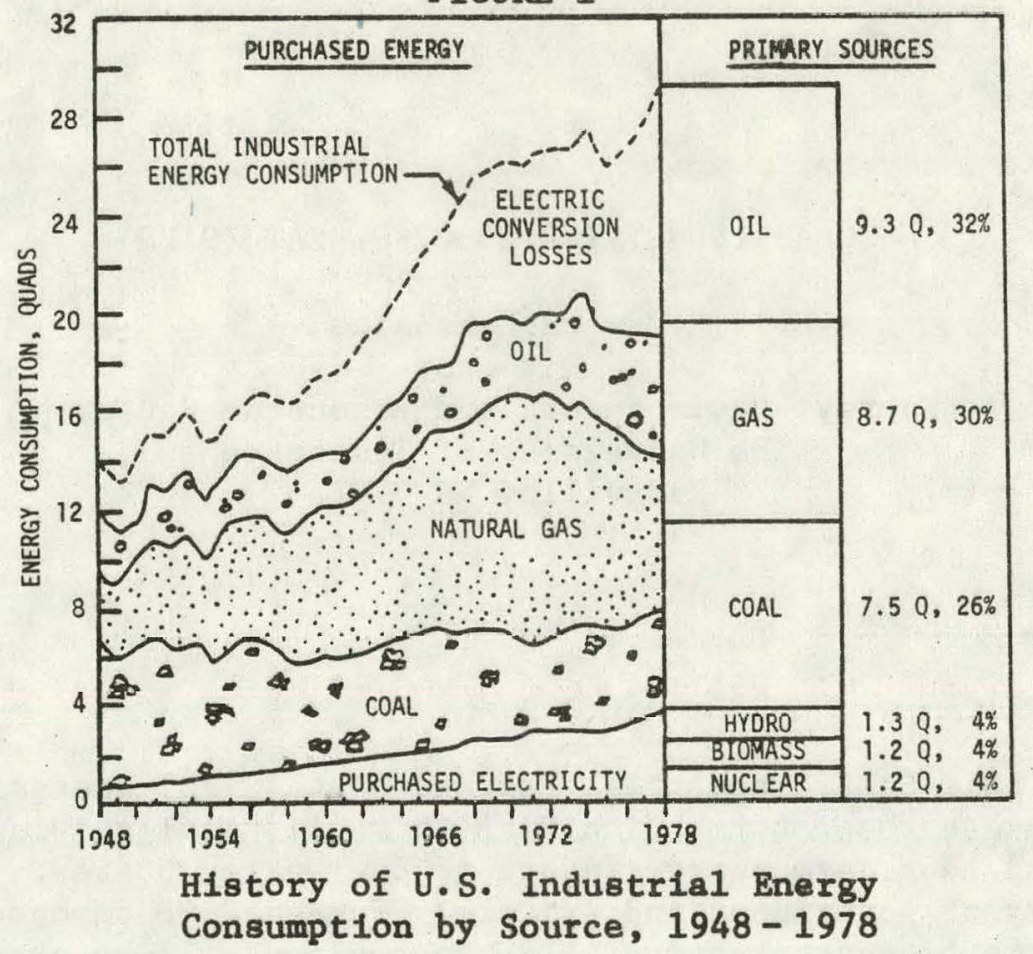

12 percent from nuclear reactors, and the remaining 44 percent from coal. Over the past two decades, consumption of electricity in the industrial sector has increased steadily, whereas coal consumption for direct industrial process heat has decreased slightly. Natural gas consumption has decreased markedly since the early 1970s, and 1iquid petroleum product use has risen considerably in the last decade despite price increases and the Arab oil embargo.

Industrial energy consumption is concentrated in six large industry categories (metals, chemicals, petroleum, paper, glass-clay-stone products, and food). Over half of the energy needs are for Industrial process heat. Therefore, energy management in these industries will have a large influence on industrial energy consumption. On the other hand, smaller industries contribute to quite a large share of electricity consumption for motors and lighting, and even small efficiency improvements and other means of conservation multiplied by these many users can add up to considerable energy savings.

Figure 2 shows industrial energy consumption for different industrial process heat temperature ranges plotted as a curve showing the percent of energy consumed versus required temperature. On the same graph, the operating temperatures of various SIPH collector technology is also indicated. It would appear that almost 60 percent of industrial process heat could be supplied with commerclally available solar technology today. However, this type of representation, which has been rather widespread, gives a very misleading picture of the actual potential of SIPH. Demand, especially in the lower temperature ranges, could be significantly reduced if energy conservation were taken into account, for instance. In order to assess the real demand potential of SIPH, a number of factors and barriers affecting this demand will be reviewed in this assessment. 


\section{FIGURE 2}

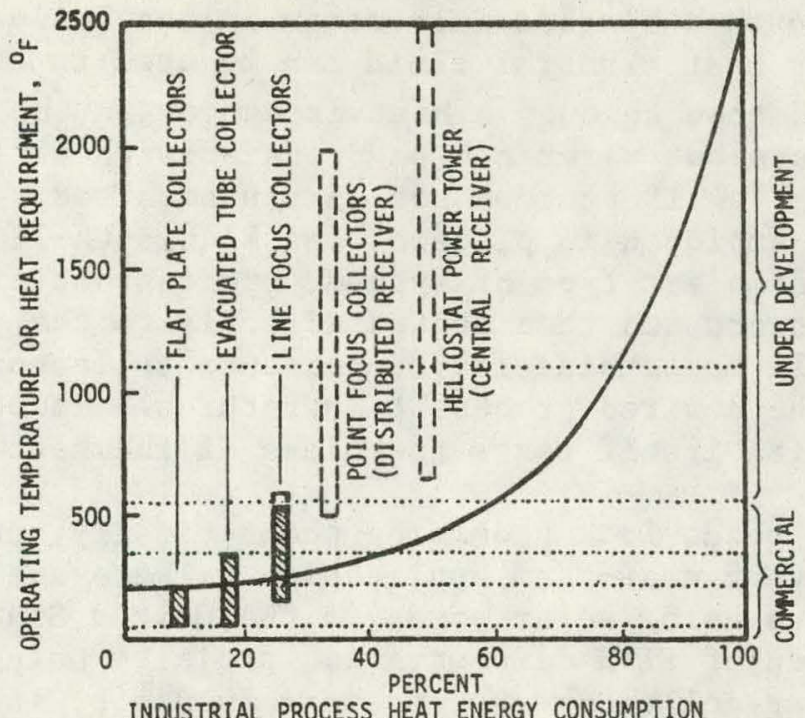

Energy Consumption for Industrial Process Heat and
Operating Temperatures of Ava1lable SIPH Technology

A recent SERI study estimates the potential of SIPH to be less than $0.25 \mathrm{Q}$ by the year 2000, even with relatively ambitious cost reductions. The Domestic Policy Review of Solar Energy targets this potential at $2.6 \mathrm{Q}$ by the year 2000. About 1 in 7 factories would have to use solar energy in some form to achieve this projection, and 5.9 billion square feet of collectors (primarily of the concentrating type) would be required. With the present political climate and doubtful support for solar R \& D, it appears unlikely that favorable conditions will exist to even replace $0.25 \mathrm{Q}$ of fossil energy with SIPH by the year 2000 . If the ultimate goal (as stated recently by DOE) is to reduce the vulnerability of the United States to Imported oll cut-off, then investment in energy conservation, cogeneration, and lower-cost alternate energy technology may be more effective in achieving this end than allocating large amounts of funds to SIPH development.

\section{B. SIPH Technology Assessment}

The requirement for durable and reliable equipment in the case of solar residential applications is very important, but for industrial applications it is even more crucial. SIPH systems must have (1) highly reflective, durable mirrors for concentrators, (2) absorbers with high absorptivity, low emissivity, and low heat loss, (3) simple, durable and reliable tracking mechanisms, and (4) flexible couplings that can withstand high temperatures, pressures, and rotation with flowing fluid. If SIPH hopes to gain a market, then the SIPH equipment must conform to the durability and reliability standards expected and obtained by industry for their other operating equipment. All collectors currently being used in SIPH applications require additional $R \& D$ to improve durability, reliability, efficlency, and to substantially reduce cost.

A variety of SIPH system designs are possible, depending on the service required and the process temperatures needed. In a flash boiler process 
steam system, water under high pressure is circulated directly through the collectors and then flashed into steam in the boiler. Alternately, a freeze-resistant heat transfer fluld can be used to circulate through the collectors and then through a heat exchanger in the boller to produce steam. Process hot water can be produced with a simflar system (without the boiler). If process hot air is required, a liquid-to-air heat exchanger is employed in place of the liquid-to-liquid heat exchanger. In the simplest type of system, process hot air is circulated through the collectors and then ducted directly to the end-use point. It is also possible to combine low-temperature collectors with a heat pump to achieve the desired process temperatures. In other applications, the process material itself takes the place of the heat exchanger.

Even though solar ponds look promising theoretically, many practical problems will prevent near-term application. There are at present no SIPH demonstrations using solar ponds in the United States. In the last few years, a number of SIPH demonstration projects using flat plate or concentrating solar collector systems were funded by the federal government or privately by the industrial consumer. A summary of fourteen of these applications is given in Table 1. Information was obtained by telephone interview and site visits for thirteen of these; one privately funded installation refused permission for a site visit because the system has been inoperative for some time due to storage fallure.

A large number of problems have occurred with these SIPH systems. The flat plate collectors used developed leaks or had problems with plastic glazing deterioration. Although the air systems operated well with good efficiency, they have large parasitic power losses. Poor system design has led to very low overall system efficlencies. Evacuated tube collectors have suffered relatively frequent failures due to thermal shock. Other problems were seal leaks in pumps, improper pump selection, leaks around flare fittings, wetting of insulation, and peeling of the selective coating on some absorbers. Operation and maintenance have turned out to be such problems that three facilities are presently not operating because the owners feel that $0 \& M$ costs are far in excess of the value of the energy that could be recelved from the system. And despite several million dollars in expenditures for data collection, very little useful and reliable data is available because of data acquisition system failures.

Because of this performance record, some industrial users have acquired negative attitudes and lack of confidence towards solar energy. None of the users interviewed have any plans for expansion of their SIPH facility in the near term, if this requires investment of corporate funds. SIPH systems are unanimously judged as heing too expensive for ueur lerm uoc. However, a number of users sald they were quite satisfied with the government-funded systems.

Among SIPH system suppliers, there appears to be very little agreement on future collector costs. Projections from manufacturers range from $\$ 35 / \mathrm{MBtu}$ per year to $\$ 165 / \mathrm{MBtu}$ per year of energy deliviered ( $1 \mathrm{MBtu}=$ $\left.10^{6} \mathrm{Btu}\right)$. A recent study shows that the demonstration projects averaged system costs of about $\$ 70 / \mathrm{ft}^{2}$, with a cost breakdown as follows: collector cost 40 percent, construction cost 20 percent, support structure 
TABLE 1

Summary of SIPH Field Applications

\begin{tabular}{|c|c|c|c|c|c|c|c|}
\hline NAME & Campbell Soup Co. & Riegel Textile Corp. & $\begin{array}{l}\text { York Building } \\
\text { Products, Inc. }\end{array}$ & Gilroy Foods, Inc. & Gold Kist, Inc. & $\begin{array}{l}\text { Lamanuzzi \& } \\
\text { Pantaleo Foods }\end{array}$ & West Point Pepperell \\
\hline LOCATION & $\begin{array}{l}\text { Sacramento, } \\
\text { California }\end{array}$ & $\begin{array}{l}\text { Lafrance, } \\
\text { South Carol ina }\end{array}$ & $\begin{array}{l}\text { Harrisburg, } \\
\text { Pennsylvania } \\
\end{array}$ & $\begin{array}{l}\text { Gilroy, } \\
\text { California }\end{array}$ & $\begin{array}{l}\text { Decatur, } \\
\text { Al abama }\end{array}$ & $\begin{array}{l}\text { Fresno, } \\
\text { California } \\
\end{array}$ & $\begin{array}{l}\text { Fairfax, } \\
\text { Alabama }\end{array}$ \\
\hline APPLICATION & Soup can washing & Textile dyeing & $\begin{array}{l}\text { Concrete block } \\
\text { curing }\end{array}$ & $\begin{array}{l}\text { Onion and garlic } \\
\text { drying }\end{array}$ & Soy bean drying & $\begin{array}{l}\text { Raisin and prune } \\
\text { drying }\end{array}$ & Fabric drying \\
\hline COLLECTOR TYPE & $\begin{array}{l}\text { Flat plate } \\
\text { (Solargenics) and } \\
\text { parabolic trough } \\
\text { (Acurex) }\end{array}$ & $\begin{array}{l}\text { GE TC-100 } \\
\text { evacuated tube }\end{array}$ & $\begin{array}{l}\text { AAl Corporation } \\
\text { fixed focus } \\
\text { tracking mirror } \\
\text { concentrator }\end{array}$ & $\begin{array}{l}\text { GE TC- } 100 \\
\text { evacuated tube }\end{array}$ & $\begin{array}{l}\text { Solaron } \\
\text { single glazed } \\
\text { flat plate (air) }\end{array}$ & $\begin{array}{l}\text { Site-built } \\
\text { single glazed (air) }\end{array}$ & $\begin{array}{l}\text { Honeywell } \\
\text { parabolic trough }\end{array}$ \\
\hline $\begin{array}{l}\text { AVERAGE OPERATING } \\
\text { TEMPERATURE }\end{array}$ & $82^{\circ} \mathrm{C}\left(180^{\circ} \mathrm{F}\right)$ & $120^{\circ} \mathrm{C}\left(250^{\circ} \mathrm{F}\right)$ & $71^{\circ} \mathrm{C}\left(160^{\circ} \mathrm{F}\right)$ & $88^{\circ} \mathrm{C}\left(190^{\circ} \mathrm{F}\right)$ & $66^{\circ} \mathrm{C}\left(150^{\circ} \mathrm{F}\right)$ & $66^{\circ} \mathrm{C}\left(150^{\circ} \mathrm{F}\right)$ & $\begin{array}{l}160^{\circ} \mathrm{C}\left(320^{\circ} \mathrm{F}\right) \\
0.58 \mathrm{MPa}(85 \mathrm{psia})\end{array}$ \\
\hline $\begin{array}{l}\text { FLUID USED IN } \\
\text { COLLECTOR LOOP }\end{array}$ & Pressurized water & $\begin{array}{l}\text { Ethylene glycol } \\
\text { /water }\end{array}$ & $\begin{array}{l}\text { Ethylene glycol } \\
\text { /water }\end{array}$ & Nater & Air & Air & Pressurized water \\
\hline COLLECTOR AREA & $7300 \mathrm{ft}^{2}\left(680 \mathrm{~m}^{2}\right)$ & $6680 \mathrm{ft}^{2}\left(620 \mathrm{~m}^{2}\right)$ & $9200 \mathrm{ft}^{2}\left(855 \mathrm{~m}^{2}\right)$ & $5950 \mathrm{ft}^{2}\left(550 \mathrm{~m}^{2}\right)$ & $13100 \mathrm{ft}^{2}\left(1220 \mathrm{~m}^{2}\right)$ & $20500 \mathrm{ft}^{2}\left(1900 \mathrm{~m}^{2}\right)$ & $7490 \mathrm{ft}^{2}\left(700 \mathrm{~m}^{2}\right)$ \\
\hline SIORAGE & 17,000 gal. & 8,000 gal. & Built into process & None & None & $14000 \mathrm{ft}^{3}\left(330 \mathrm{~m}^{3}\right)$ & None \\
\hline $\begin{array}{l}\text { DESIGNED ANNUNL } \\
\text { OUTPUT }\end{array}$ & $2160 \mathrm{MBtu} / \mathrm{yr}$ & $1400 \mathrm{MBtu} / \mathrm{yr}$ & $1500 \mathrm{MBtu} / \mathrm{yr}$ & $2340 \mathrm{MBtu} / \mathrm{yr}$ & $3700 \mathrm{MB} \mathrm{tu} / \mathrm{yr}$ & $2300 \mathrm{MBtu} / \mathrm{yr}$ & $1220 \mathrm{MBtu} / \mathrm{yr}$ \\
\hline $\begin{array}{l}\text { ACTUAL ANNUAL } \\
\text { ENERGY DEL IVERED }\end{array}$ & N/A & $370 \mathrm{MBtu} / \mathrm{yr}$ & $320 \mathrm{MBtu} / \mathrm{yr}$ & $930 \mathrm{MBtu} / \mathrm{yr}$ & $744 \mathrm{MBtu} / \mathrm{yr}$ & $\begin{array}{l}1260 \text { MBtu (1978) } \\
647 \mathrm{MBtu}(1979)\end{array}$ & $\begin{array}{l}\text { No useful energy } \\
\text { since startup }\end{array}$ \\
\hline $\begin{array}{l}\text { ACTUAL } \\
\text { SYSTEM EFFICIENCY }\end{array}$ & $N / A$ & $8 \%$ & $9 \%$. & $32 \%$ & $19 \%$ & $18 \%$ & $N / A$ \\
\hline DATE. OPERAIIONAL & November 1977 & June 1978 & September 1978 & August 1979 & July 1978 & July 1978 & December 1978 \\
\hline DATE OF VISIT & 4 Dec 1980 & 1 Dec 1980 & $29 \mathrm{Dec} 1980$ & 31 Dec 1980. & 9 Dec 1980 & 31 Dec 1980 & $16 \mathrm{Dec} 1980$ \\
\hline $\begin{array}{ll} & \text { OESIGN: } \\
\text { COST } & \text { CONSTRUCTION: } \\
& \text { MONITORING: }\end{array}$ & $\begin{array}{l}D=\$ 204,000 \\
C=\$ 581,000 \\
M=\$ 550,000\end{array}$ & $\begin{array}{l}D=\$ 250,000 \\
C=\$ 610,000 \\
M=\$ 150,000\end{array}$ & $\begin{array}{l}D=\$ 114,000 \\
C=\$ 450,000 \\
M=\$ 100,000\end{array}$ & $\begin{array}{l}D=\$ 226,000 \\
C=\$ 618,000 \\
M=\$ 178,000\end{array}$ & $\begin{array}{l}D=\$ 291,000 \\
C=\$ 823,000 \\
M=\$ 186,000\end{array}$ & $\begin{array}{l}D=\$ 261,000 \\
C=\$ 545 ; 000 \\
M=\$ 154,000\end{array}$ & $\begin{array}{l}D=\$ 146,000 \\
C=\$ 598,000 \\
M=\$ 150,000\end{array}$ \\
\hline $\begin{array}{l}\text { NEAR-TERM PLANS } \\
\text { FOR EXPANS ION. WITH } \\
\text { COMPANY FUNDS }\end{array}$ & No, too expensive & No, too expensive & No, too expensive & No & No, tọo expensive & No, too expensive & No, too expensive \\
\hline
\end{tabular}

cont. 
TABLE 1 (Continued)

Summary of SIPH Fleld Applications

\begin{tabular}{|c|c|c|c|c|c|c|c|}
\hline NAME & $\begin{array}{l}\text { Tropicana Products, } \\
\text { Inc. }\end{array}$ & Johnson \& Johnson & Home Laundry Co. & Dow Chemical & $\begin{array}{l}\text { Red Star Industrial } \\
\text { Service }\end{array}$ & $\begin{array}{l}\text { General Extrusion, } \\
\text { Inc. }\end{array}$ & Anhersser-Busch \\
\hline LOCATION & $\begin{array}{l}\text { Bradenton, } \\
\text { Florida }\end{array}$ & $\begin{array}{l}\text { Sheman, } \\
\text { Texas }\end{array}$ & $\begin{array}{l}\text { Pasadena, } \\
\text { California }\end{array}$ & $\begin{array}{l}\text { Dalton, } \\
\text { Georgia }\end{array}$ & $\begin{array}{l}\text { Fresno, } \\
\text { California }\end{array}$ & $\begin{array}{l}\text { Youngs town, } \\
\text { Ohio }\end{array}$ & $\begin{array}{l}\text { Jacksonville, } \\
\text { Florida }\end{array}$ \\
\hline APPLICATION & $\begin{array}{l}\begin{array}{l}\text { Fruit juice } \\
\text { processing }\end{array} \\
\end{array}$ & Gauze bleaching & $\begin{array}{l}\text { Cormercial } \\
\text { laundering }\end{array}$ & Latex production & $\begin{array}{l}\text { Industrial } \\
\text { laundering }\end{array}$ & $\begin{array}{l}\text { Extrusion of } \\
\text { aluminum parts }\end{array}$ & $\begin{array}{l}\text { Brewery } \\
\text { pasteurizing }\end{array}$ \\
\hline COLLECTOR TYPE & $\begin{array}{l}\text { GE TC- } 300 \\
\text { evacuated tube }\end{array}$ & $\begin{array}{l}\text { Acurex Model } 3001 \\
\text { parabol ic trough }\end{array}$ & $\begin{array}{l}\text { Dell } \\
\text { parabolic trough }\end{array}$ & $\begin{array}{l}\text { Suntech-Hexcel } \\
\text { parabolic trough }\end{array}$ & $\begin{array}{l}\text { Ing Manufacturing } \\
\text { flat plate (1 iquid) }\end{array}$ & $\begin{array}{l}\text { General Extrusion } \\
\text { Model LTC-357 Conc. } \\
\text { (tracking seasonal } \\
\text { adjusted manually) }\end{array}$ & $\begin{array}{l}\text { Owens-1llinois } \\
\text { "Sun-Pak" } \\
\text { evacuated tube }\end{array}$ \\
\hline $\begin{array}{l}\text { AVERAGE OPERATING } \\
\text { TEMPERATURE }\end{array}$ & $\begin{array}{l}150^{\circ} \mathrm{C}\left(300^{\circ} \mathrm{F}\right) \\
1.03 \mathrm{mpa}(150 \text { psia })\end{array}$ & $\begin{array}{l}175^{\circ} \mathrm{C}\left(345^{\circ} \mathrm{F}\right) \\
0.86 \mathrm{MPa}(125 \mathrm{psia})\end{array}$ & $\begin{array}{l}170^{\circ} \mathrm{C}\left(340^{\circ} \mathrm{F}\right) \\
0.86 \mathrm{MPa}(125 \mathrm{psia})\end{array}$ & $\begin{array}{l}177^{\circ} \mathrm{C}\left(350^{\circ} \mathrm{F}\right) \\
0.96 \mathrm{MPa}(140 \mathrm{psia})\end{array}$ & $57^{\circ} \mathrm{C}\left(135^{\circ} \mathrm{F}\right)$ & $88^{\circ} \mathrm{C}\left(190^{\circ} \mathrm{F}\right)$ & $63^{\circ} \mathrm{C}\left(145^{\circ} \mathrm{F}\right)$ \\
\hline $\begin{array}{l}\text { FLUID USED IN } \\
\text { COLLECTOR LOOP }\end{array}$ & Pressurized water & Pressurized water & Pressurized water & $\begin{array}{l}\text { Dowtherm-LF } \\
\text { organic fluid }\end{array}$ & Water (Jrain-down) & Light oil & Water \\
\hline COLLECTOR AREN & $10000 * t^{2}\left(930 \mathrm{~m}^{2}\right)$ & $11520 \mathrm{ft}^{2}\left(1070 \mathrm{~m}^{2}\right)$ & $6500 \mathrm{ft}^{2}\left(600 \mathrm{~m}^{2}\right)$ & $9930 \mathrm{ft}^{2}\left(920 \mathrm{~m}^{2}\right)$ & $6500 \mathrm{ft}^{2}\left(600 \mathrm{~m}^{2}\right)$ & $4400 \mathrm{ft}^{2}\left(410 \mathrm{~m}^{2}\right)$ & $4600 \mathrm{ft}^{2}\left(460 \mathrm{~m}^{2}\right)$ \\
\hline STORAGE & None & None & $\begin{array}{l}\text { Small buffer } \\
\text { storage tank only }\end{array}$ & None & 12,000 gal. & None & Not working \\
\hline $\begin{array}{l}\text { OESIGNEO ANNUAL } \\
\text { OUTPUT }\end{array}$ & $2700 \mathrm{M} \exists \mathrm{tu} / \mathrm{yr}$ & $1400 \mathrm{MBtu} / \mathrm{yr}$ & $1600 \mathrm{MBtu} / \mathrm{yr}$ & $2540 \mathrm{MBtu}$ & $\begin{array}{l}\text { Unable to obtain } \\
\text { report. Brochure } \\
\text { contains errors. }\end{array}$ & \multirow{3}{*}{$\begin{array}{l}\text { Very little hard } \\
\text { data available. } \\
\text { Privately funded } \\
\text { plant. } \\
\text { Only plant using } \\
\text { solar-assisted } \\
\text { heat pump. }\end{array}$} & $N / A$ \\
\hline $\begin{array}{l}\text { ACTUAL ANNUAL } \\
\text { ENERGY DELIVEFED }\end{array}$ & N/A & $\begin{array}{l}1000 \mathrm{MBtu} / \mathrm{yr} \\
\text { (estimated from } \\
7 \text { months of data) }\end{array}$ & $N / n$ & N/A & N/A & & $\mathrm{N} / \mathrm{A}$ \\
\hline $\begin{array}{l}\text { ACTUAL } \\
\text { SYSTEM EFFICIENCY }\end{array}$ & N/A & $N / A$ & N/A & N/A & N/A & & $N / A$ \\
\hline DATE OPERATIONAL & $\begin{array}{l}\text { Projected: } 2 / 1980 . \\
\text { Not operating as } \\
\text { of date of visit. }\end{array}$ & January 1980 & April 1981 (est.) & December 1980 & Summer 1977 & September 1977 & April 1978 \\
\hline DNTE OF VISIT & 17 Dec 1980 & 8 Dec 1980 & 30 Dec 1980 & 9 Dec 1980 & 31 Dec 1980 & 2 Jan 1981 & N/A \\
\hline $\begin{array}{l}\text { OESIGN: } \\
\text { COST CONSTRUCTION: } \\
\text { MONITORING: }\end{array}$ & $\begin{array}{l}D=\$ 235,000 \\
C=\$ 1.375,000 \\
M=\$ 25,3,000\end{array}$ & $\begin{array}{l}D=\$ 214,000 \\
C=\$ 1,613,000 \\
M=\$ 200,000\end{array}$ & $\begin{array}{l}D=\$ 167,000 \\
C=\$ 801,000 \\
M=\$ 55,000 \\
\text { (ext. betng neg.) }\end{array}$ & $\begin{array}{l}D=\$ 195,000 \\
C=\$ 870,000 \\
M=N / A\end{array}$ & $\begin{array}{l}c=\$ 250,000 \\
(20 \% \text { privately } \\
\text { funded) }\end{array}$ & $\begin{array}{l}\$ 150,000 \text { (est.) } \\
(100 \% \text { privately } \\
\text { funded) }\end{array}$ & $\begin{array}{l}100 \% \text { privately } \\
\text { funded }\end{array}$ \\
\hline $\begin{array}{l}\text { NEAR-TERM PLANS } \\
\text { FOR EXPANSION WITH } \\
\text { COMPANY FUNDS }\end{array}$ & No, too expensive & Unsure at present & $N / A$ & No & Mo. & No & No, too expensive \\
\hline
\end{tabular}


15 percent, and miscellaneous 25 percent. Installed system costs have decreased slightly for some systems over the last few years. However, collector costs per unit area have gone up from $\$ 16 / \mathrm{ft}^{2}$ to $\$ 25 / \mathrm{ft}^{2}$ for concentrating collectors and from $\$ 12 / \mathrm{ft}^{2}$ to $\$ 22 / \mathrm{ft}^{2}$ for flat plate collectors in the last five years. Because of the materials and labor involved, projections that assume decreasing prices are simply not realistic, such as the DOE cost goals of $\$ 10 / \mathrm{MBtu}$ by 1985 and $\$ 7 / \mathrm{MBtu}$ by 1990 (MISR program). Site-generated SIPH simply cannot compete economically with other alternatives in the near term, such as conservation, cogeneration, and use of biomass and municipal waste.

\section{Non-Technical Assessment}

The majority of SIPH demonstrations have been almost entire1y funded by the federal government. There are a few privately-funded smaller applications (less than $5000 \mathrm{ft}^{2}$ of collectors), but data on performance and economics of these systems are much more difficult to obtain. Since 1976, the government has sponsored a yearly symposium on SIPH. Early theoretical studies showed an apparent potential and need for SIPH. Based on these results, fleld tests and demonstration projects were pushed too quickly, before the technology was ready and before adequate assessments of the actual market and of alternate paths were undertaken. Perhaps the major shortcoming of these fleld tests is that these SIPH technologies were applied without thorough prior energy audits for the particular industrial.plant and process and without application of low cost energy conservation and energy management. It is interesting to note that federal funding for energy conservation in industry has been minimal. Also, DOE has been spending only about 0.1 percent of 1 ts budget on cogeneration, even though as much as 20 percent could possibly be added to existing U.S. electric generating capacity by using avallable, economical sources of industrial process steam.

The government's SIPH program was not accompanied by a supportive substructure of tax and other relevant legislation to encourage SIPH applications. Industrial capital investment into energy-saving equipment to increase productivity and reduce production costs over the long term is discouraged under present financlal conditions and tax laws. Conventional fuels are still heavily subsidized on many levels, amounting to almost ten billion dollars a year. Several pleces of leglslation (state and federal) Inhibit cogeneration, even though the rationale that led to enactment is no longer valld.

Interest in energy conservation and alternate energy (Including SIPH) will largely be dependent on local energy supply conditions and the cost of energy and can be influenced by a strong national energy policy. Presently there are not enough consistent signals from the market place and elsewhere to spark this interest among industry. U.S. industry tends to emphasize quick profits over long-term benefits; this attitude does not induce Industrial management to go solar anytime soon. There are only a handful of manufacturers that have the capacity to produce enough concentrating collectors for larger SIPH applications. A large difference in collector quality and in willingness to provide sufficient attention and care to supply a working SIPH system was found in the demonstration projects. There ts much room for improvement in quality of 
hardware as well as service among these suppliers. A large part of concentrating collector $R \& D$ continues to be government funded; however, there are, over two hundred smaller companies who are conducting their own R \& D on al1 different types of solar collectors. From the experience with the present SIPH demonstrations, Industrial capacity for concentrating collector output should not be pushed artificlally at this time at the cost of developing a proven, rellable product and before a real demand exists. At least in the near term, the small number of manufacturers is not a significant barrier.

The SIPH demonstration program has shown that there is a lack of understanding among designers and users of how SIPH systems can be optimized. Adequately trained personnel is required for malntenance and operation of these systems. Also, there seems to be a real shortage of qualified people to conduct energy audits prior to the design and Installation of solar equipment in industrial (and other) applications. The solar industry in general suffers from a shortage of trained labor. The demonotration projecls have shown that the SIPH system must match the requirements and operational characteristics of the industrial process. The solar energy collected is only useful to the industrlal user if neither the SIPH system nor the manufacturing process are down for maintenance. Some flexibility should be built Into the SIPH system so that Its heat can be directed to alternate locations if one area 18 down for maintenance. This flexibility was lacking in several designs.

Alternate energy applications, including SIPH, are generally acknowledged to have soctal benefits which cannot be evaluated strictly in terms of payback or 1ife-cycle costing. Conversely, the prices of coal or nuclear energy do not reflect the burden they place on the environment and on people's health in the course of mining, use, or waste disposal. 011 and gas prices do not yet account for their true replacement costs. Solar energy is also very much a political problem. It must at present still compete with many favored, powerful spectal interests. A political climate conducive to solar energy will include definite goals and objectives, appropriate tax incentives, low-interest financing, solar mandates, equipment standards, and a public education program, as is the case in California, for example. Table 2 lists some of the most important barriers to SIPH application.

TABLE 2

Barriers to SIPH Application

\begin{tabular}{|c|c|}
\hline APPLIED, TECHMICAL & FINAMCIAL, POLITICAL \\
\hline $\begin{array}{l}\text { 1. Dismal Performance Experience } \\
\text { 2. Laek of Avallable Land } \\
\text { 3. Inadequate R\&D } \\
\text { 4. Operations Maintenance } \\
\text { Problems } \\
\text { 5. Design Problems } \\
\text { 6. Low Efficiency } \\
\text { 7. Unsultable Climate in Some } \\
\text { Locations } \\
\text { 8. Unsultable End-Use Match } \\
\text { 9. Shortage of Qualified Labor }\end{array}$ & $\begin{array}{l}\text { 1. Lack of National Polfcy } \\
\text { 2. High Cost } \\
\text { 3. Subsidized Competing Fuels } \\
\text { 4. Unfavorable Tax Laws } \\
\text { 5. Energy Conservation Much More } \\
\text { Effective } \\
\text { 6. Large Läpital Investment } \\
\text { Required } \\
\text { 7. No Quick' Profits } \\
\text { 8. Cogeneration Preferable } \\
\text { 9. Lack of Interest, Coamitument }\end{array}$ \\
\hline
\end{tabular}




\section{Policy Implications}

Th1s assessment summarizes the policy implications for the industrial sector of a number of low demand energy futures studies. It is not surprising that they unanimously recommend a rise in energy prices to reflect the true replacement cost of oil and gas and to provide a consistent"signal to industry and other consumers to increase investment in energy conservation. Federal and state governments must first of all set firm goals and policles to curb demand and encourage conservation, and this decision must then be supported with appropriate legislation, especially in the area of utility regulations. Prohibitive regulations against cogeneration especially must be removed. Financially, tax reform, tax credits and other capital investment incentives w111 be required, although the actual amounts of this assistance will be determined through interaction and competition with the many other pressures on federal and state budgets. Most striking in these studies is the recommendation that federally sponsored $R \& D$ be redirected towards more practical, short-term, low-cost technology in solar energy and energy conservation in general.

\section{E. Conclusion and Recommendations}

Despite government expenditures of over 100 million dollars per year since FY 1978 for solar thermal development and demonstration, there has only been one totally commercial SIPH sale of signiffcance. Many technical problems as well as soclo-economic barriers st111 exists. In light of these, a contribution from SIPH of at most $0.25 Q$ by the year 2000 may be expected with approprlate government support. However, much greater benefits can be achieved through a variety of energy conservation measures. Economically, there is a much greater incentive for industry to invest in energy conservation, if concrete information for specific industries were avallable. Heat recovery systems, for example, are quite reliable and have payback perlods consistent with industry requirements. Industry traditionally will not invest in high-risk, unfamiliar systems outside the company's product line. The SIPH demonstration program has failed to attract capital investments for solar energy applications in industry. The almost 100 percent government-financed demonstrations of on-site solar thermal industrlal process heat plants are viewed as "expensive toys". Further demonstrations (w1th even larger systems) at this time are nelther 1ikely to achieve cost reductions nor increase user confidence. On the other hand, development of alternate technology to provide industrial process heat such as efficient process steam plants using municipal wastes as fuel or gasifiers utilizing agricultural waste may result in exportable products and technology of . Interest to other countries.

Specifically, the following recommendations have resulted from this assessment :

1. DOE or some other agency designated by the President must develop a consistent but realistic energy plan which includes policy planning as well as periodic evaluation. The emphasis must be on the most cost-effective methods for the near term. 
2. Legislation must be consistent in supporting this policy at all levels of government, and çonflicting signals (1.e. low fossil fuel prices and subsidies for conventional energy supplies) must be removed.

3. Federal funds must be directed towards $R \& D$ support for efficiency improvements in industry, including waste heat recovery and cogeneration. Such emerging technologies as thermoelectric/thermal and photovoltaic/thermal cogeneration which produce both electricity and low-grade heat and which promise to be very durable and reliable should receive careful attention.

4. The use of biomass and municipal wastes as industrial fuels should be encouraged in the near term, because these can make a major impact in the displacement of scarce fossil fuels. However, nther sources of alternate energy, such as: wind, should be considered and supported where appropriate.

5. Government (federal and state) involvement in SIPH should continue in the area of materials and components testing and roocarch, in infurmation and education, and in providing tax and financial incentives. The government should also assist in the formulation of standards to help industry achieve confidence in solar thermal equipment. State and local governments should encourage energy conservation standards.

6. SIPH demonstration systems in the field that have not operated for a year or only intermittently should be scrapped and funding discontinued. These systems are an embarrassment and will not help improve the image of solar energy. Good operating systems should be optimized, if necessary with some additional funding. Projects presently under. construction should be reviewed with the aim of achieving better operational results and efficiencies by quality improvement in the hardware and by incorporating cost-effective methods of conservation in the entire manufacturing process.

7. There is very little need at present for additional SIPH market and projection studies. Data from the upgraded SIPH demonstration sites should be collected and evaluated for a period of not less than five years, and the results must be made known to the public. There is a need for more candid reporting of negative results in order that past mistakes will not be repeated in future projects. 


\section{INTRODUCTION}

Industrial socleties have historically been dependent on a plentiful and inexpensive supply of energy. The present energy crisis exists because of Increasing demands for decreasing supplies of low-cost oll and natural gas. In order to prevent soclal, polltical, and economic upheavals, it is imperative that energy demand be curbed and alternate energy sources be developed, especially in the United States which has been consuming a disproportionately large share of energy per capita in comparison to the rest of the world. As developing countries raise their standard of living and establish some sort of industrial base, their demand for fossil fuels will significantly increase. Politically, it is a must for the United States to demonstrate the advantages of alternate energy technologies in a wide range of applications and to support this development with consistent, rational government and institutional support*. Since private capttal as well as avallable tax dollars are limited commodities, the areas must be pinpointed where development and support will be most effective.

\section{A. Assessment Objectives}

The aim of this Solar Industrial Process Heat (SIPH) assessment is to candidly examine the contribution SIPH is realistically able to make in the near and long-term energy futures of the United States. The performance history of government and privately funded SIPH demonstration projects and the present status of SIPH technology will be discussed. Before making final recommendations, the influence of economic and sociopolitical factors (which have a very large effect on the acceptability and application of any new, alternate energy technology) will be considered also.

A variety of solar systems are technically capable of supplying the heat required for many industrial processes, as shown In Figure 3. Among many other considerations, the cholce depends on the process temperatures required. Solar energy can also be used for preheating in h1gh-temperature applications. Flat-plate collector technology is described in detall in the assessment of active solar heating by Dr. Susumu Karaki and Dr. George 0 . L bf, and solar thermal systems (central receiver and large-scale distributed recelver systems) are treated in the assessment by Dr. Alvin F. Hildebrandt. Therefore, this report shall focus on evacuated tube, parabolic trough, and multiple reflector solar collectors. Auxiliary equipment which is part of a SIPH system such as pumps, blowers, controls, and heat exchangers and storage (where applicable) are discussed also.

Any serlous evaluation of the potential of SIPH must incorporate consideration of past energy use patterns of the industrial sector as well as possible applications of more appropriate alternatives, including conservation. It is important that goals for SIPH applications be defined.

*See Reference 1 for a discussion of strateglc soctal and foreign policy issues related to U.S. dependence on forelgn ofl and the resulting negative balance of payments. 
INDUSTRIAL PROCESS HEAT APPLICATION

SOLAR SYSTEM

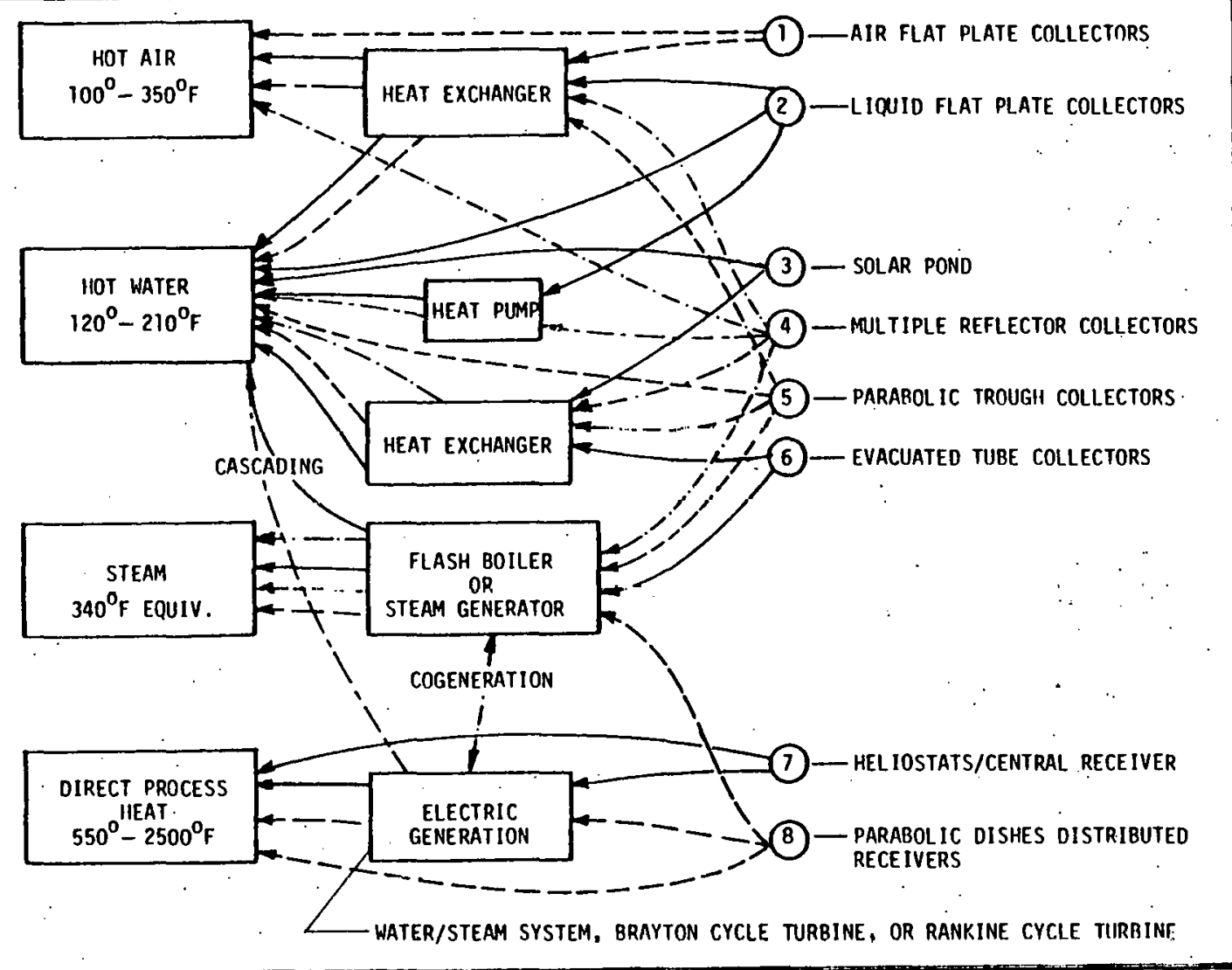

Solar Systems for Industrial Applications

Is the technology to be used as a replacement for ofl and natural gas (hopefully at a lower cost), to reduce industrial energy consumption, or to provide a cushion against future energy supply interruptions? The answer will depend not only on technological facts and figures, but on the underlying philosophy on energy demand and supply, of which there are basically three views:

- Supplies must be Increased at any cost to meet rising demand.

- Demand can be reduced to accommodate dwindling supplies.

- Supply and demand can be appropriately matched in each application to minimize waste and achieve maximum effectiveness.

\section{B. Industrial Energy Consumption}

The Industrial sector is the largest user of energy in the United States, as 1llustrated in Figure 4 (from Refs. 2,3). The U.S. Department of Energy (DOE) defines this sector to include agriculture, mining and petroleum extraction, contract construction, and manufacturing. However, in this report, energy use by agriculture will be treated in a separate section. The industrial consumption data presented here will not include 
FIGURE 4

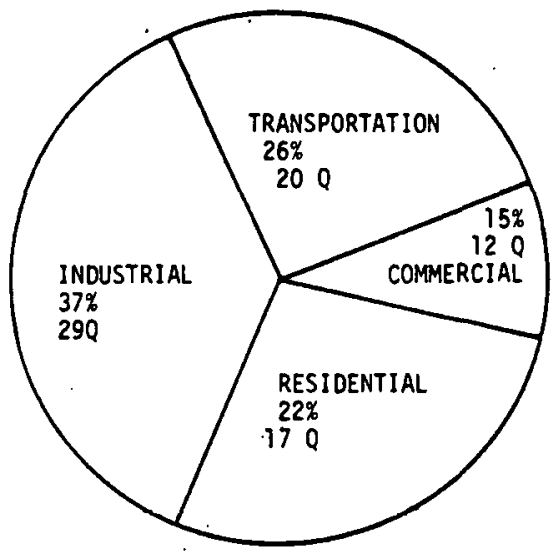

1979 U.S. Energy Consumption by Sector
FIGURE 5

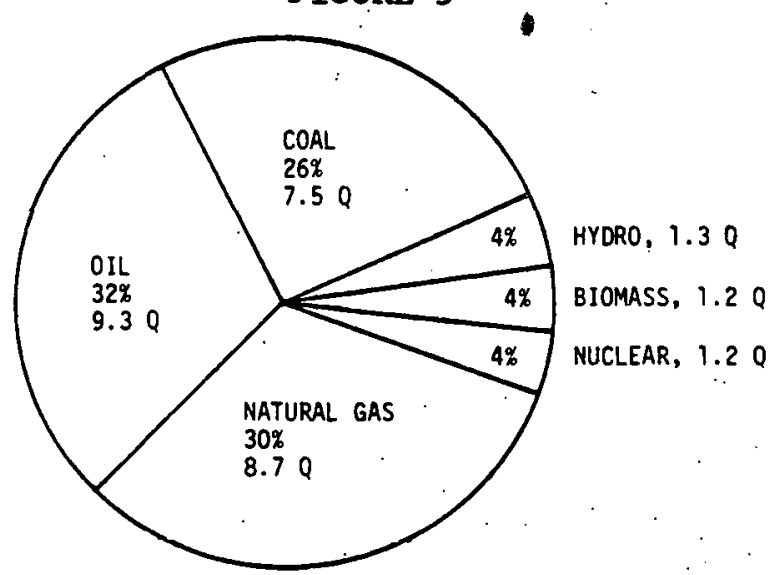

Industrial Energy Consumption by. Primary Source for 1978

agriculture, which constitutes about 4 percent of the industrial sector as defined by DOE. Manufacturing consumes the largest share with 84 percent, with mining using 8 percent and construction 4 percent.

Industrial energy consumption can be analyzed in a number of ways: (1) from the point of view of energy supply, price, and avallability, (2) with respect to user, type of manufacturing, and location, and (3) on the basis of service required, i.e. low-temperature water heating, steam, motor drive, lighting, etc. All three viewpoints can yield important information for a realistic assessment of the potentlal for SIPH applications.

\section{Industrial Energy Supply}

Figure 5 shows total industrial energy consumption for 1978 broken down into primary source categorles (from Ref. 6), and Figure 6 illustrates the history of industrlal energy consumption since 1948 (from Ref. 2). This information 18 combined in Figure 1 in the Executive Summary. Electric conversion losses attributable to purchased electricity by the industrial sector have been represented separately to indicate one important problem which confronts industrial consumers; electricity cannot be indiscriminately substituted for petroleum-based fuels unless this electricity is either generated from coal or renewable resources, or cogeneration and cascading are employed to utllize this large amount of waste heat for industrial processes. The cost of electricity can be expected to increase steadily as petroleum and natural gas prices are becoming deregulated and as $^{\circ}$ the proportion of expensive newer plants increases in the electric generating pool (Ref. 4). In 1978, 14 percent of all the electricity generated nat lonwide came from natural gas, 16 percent from oil, about 14 percent from hydro, 12 percent from nuclear reactors, and the remaining 44 percent from coal (Ref. 5). Over the past two decades, consumption of electricity in the industrial sector has increased steadily, whereas coal consumption for direct industrial heat has decreased slightly. Natural gas consumption has decreased markedly since the early 1970 s, and liquid petroleum product use has risen considerably in the last decade despite much higher prices and the Arab oil embargo. 


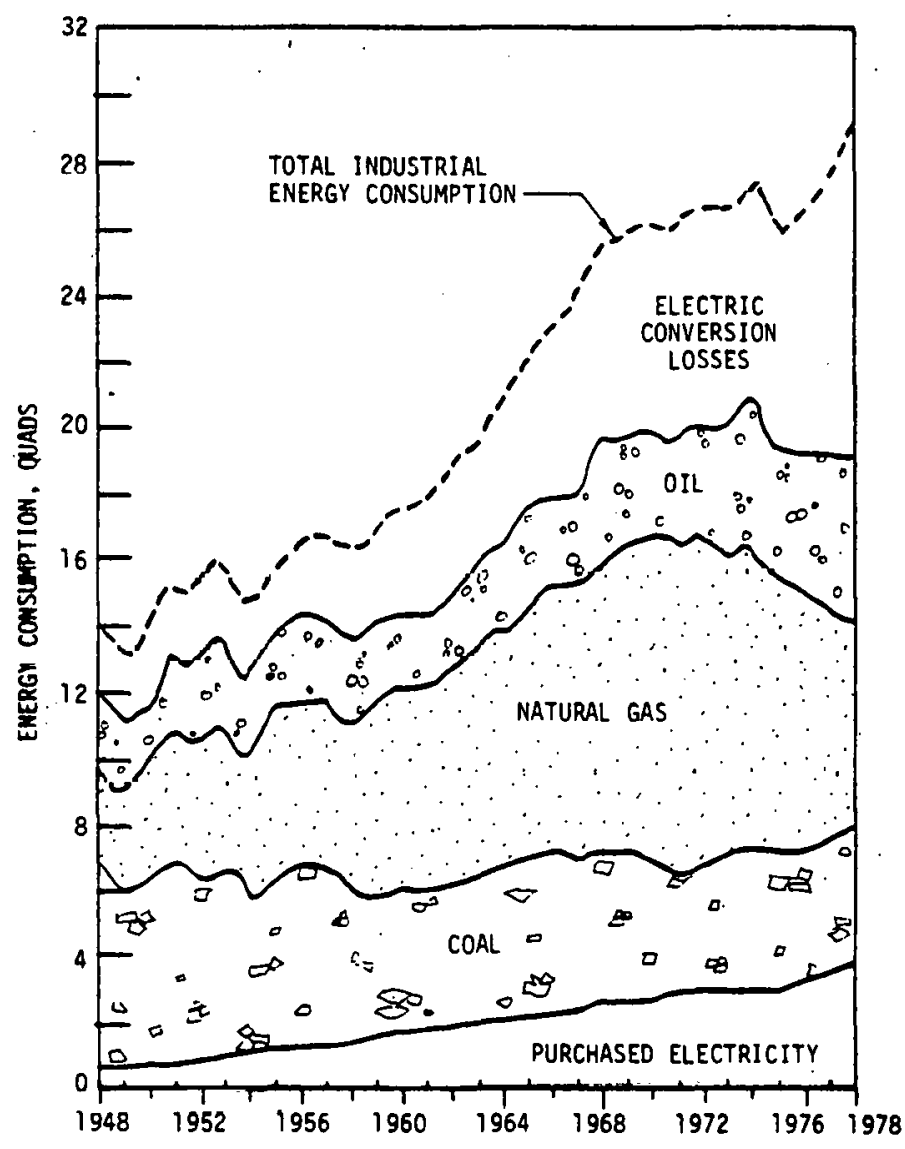

\section{H1story of Industrial Energy Consumption by Source, 1948-1978}

Serfous supply problems can be expected for industry towards the end of this century if present consumption patterns continue, and prices will rise rapidly as higher-priced new oll (domestlc and foreign) and nucleargenerated electricity increase their share in the supply mix. Therefore, it is imperative that industry not only look for new and relatively lowcost sources of energy, but also find more efficient use for the energy it consumes in order to reduce demand. As Figure 6 suggests, among the solutions to be investigated should certainly be increased direct use of coal (in place of prior conversion of coal to another energy carrier such as electricity or synfuel). Other possibilities are direct on-site generation of electricity by wind, hydro, biomass and solar energy, together with a reduction in demand through fincreased effloiency in current. processes, through using alternate processes in manufacturing and through employing efficlent load management, etc. Although only the potential. for direct applications of solar energy is being investigated here, a combination of several of the strategles mentioned above may be more costeffective and approprlate for many industrial applications; and this wist be considered by the individual manufacturer or industry and for each use, even though they are not discussed In detall here. References 4,7, $8,9,10$ may be consulted for additional information and examples of energy conservation In Industry. 


\section{Industr1al Energy Consumers}

Table 3 (complled from data in Refs. 11,12) gives a summary of the six largest manufacturing categorles with their energy service requirements. Th1s table shows some interesting 1tems; Industrial energy consumption Is concentrated in $81 x$ large Industry types, and about half of the energy needs are for Industrlal process heat. Therefore, energy management (supply substitutions and demand reductions) in these industries will have a large influence on industrial energy consumption. On the other hand, small industries contribute to quite a large share of electricity consumption for motors and lighting, and even small efficiency improvements, load management and other means of conservation multiplied by these many users can add up to considerable energy savings. Space heatIng needs are also concentrated in these other industries and represent a sizeable area for solar applications and conservation. However, the item of greatest interest to SIPH and constituting a major factor in each of the six largest industries is the need for process heat. SIPH applications depend on the process temperature to be supplied, ease of Insta1lation, economy, as well as on a number of other factors which w111 be discussed in detall in this report.

TABLE 3

Industria1 Energy Consumption by Type of Industry and Service Required, In Quads (1976 Data)

\begin{tabular}{|lcccccccc|c|c|}
\hline SERVICE INDUSTRY & Metals & Chemicals & Petroleum & Paper & $\begin{array}{c}\text { Glass, Clay } \\
\text { and Stone }\end{array}$ & Food & Other & TOTAL \\
\hline Motors, Llghting & 1.5 & 1.45 & 0.5 & 0.85 & 0.5 & 0.35 & 2.2 & 7.35 & $28 \%$ \\
Electrolysis & 1.0 & 0.4 & - & - & - & - & - & 1.4 & $6 \%$ \\
Process Heat & 1.5 & 2.25 & 2.85 & 1.9 & 1.1 & 0.75 & 1.55 & 11.9 & $46 \%$ \\
Space Heat & 0.05 & - & - & 0.05 & 0.05 & 0.05 & 0.25 & 0.45 & $2 \%$ \\
Chem. Feeds tocks & 0.1 & 2.3 & - & - & - & - & - & 2.4 & $9 \%$ \\
Metallurgic Coal & 2.3 & - & - & - & - & - & - & 2.3 & $9 \%$ \\
\hline TOTAL & 6.45 & 6.4 & 3.35 & 2.8 & 1.65 & 1.15 & 4.0 & 25.8 & $100 \%$ \\
\hline
\end{tabular}

*Includes energy lost in conversion. (35\% of total is for pumps, 30\% for compressors, 15\% for blowers and fans, and $20 \%$ for lighting and $m$ iscellaneous.)

However, as can be seen from Table 4 (with data extrapolated from Refs. $11,13)$, some regtons in the U.S. experlence different energy supply problems than others, and the solutions of course will have to be different and individualized also. Industries in areas such as Kansas, Mississippi and Puerto RIco may be much more highly motlvated to apply conservation and alternate energy sources than Virginia which is blessed with adequate supplies of coal or the West Central States (Oklahoma, Texas and Louisiana) which at least in the near term have the1r own petroleum resources.

\section{Industrial Process Heat}

Energy consumption in quads for different required industrial process temperature ranges and Industrial groups is tabulated in Table 5 (with data taken from Refs. 11,14). Reference 11 is a compilation of very detalled data on energy consumption and composition of the ten largest industrial groups in the Unfted States. A large part of the process heat requirement in the paper Industry is already oupplied by burning waste 
TABLE 4

Reglonal Breakdown of Industrlal Bnergy Use, 1975

\begin{tabular}{|c|c|c|c|}
\hline CENSUS REGION' & $\begin{array}{l}\text { ENERGY } \\
Q\end{array}$ & $\underset{\%}{\text { CONSUNPTION }}$ & NOTES \\
\hline New England & 0.6 & $3 \%$ & $\begin{array}{l}\text { High energy prices, reliance on foreign petroleum; } \\
\text { older, declining factories. }\end{array}$ \\
\hline Middle Atlantic & 3.2 & $12 \%$ & $\begin{array}{l}\text { Same as New England: high rates for electricity. } \\
\text { Pennsyivania has some coal resources. }\end{array}$ \\
\hline South Atlantic & 3.1 & $12 \%$ & $\begin{array}{l}\text { Especially Delaware and Georgfa are vulherable to } \\
\text { petroleum supply interruptions; electricity is } \\
\text { generated from oil. } \\
\text { Virginia and West Virginia have coal-based economies. }\end{array}$ \\
\hline East North Central & 5.2 & $20 \%$ & $\begin{array}{l}\text { Ohio, Illinois and Indiana have large imounts of } \\
\text { high-sulphur coal, are fmporting Western coal. } \\
\text { Wisconsin. Michigan are heavy users of fossil fuels: }\end{array}$ \\
\hline East South Central & 1.9 & $7 \%$ & $\begin{array}{l}\text { Kentucky has coal-based economy. } \\
\text { Tennessee and Alabama have benefitted from TVA. } \\
\text { Misstssidpi's ecnnnmy is hasod on increasingly scarce } \\
\text { cheap natural gas which is being replaced by. oil. }\end{array}$ \\
\hline West South Central & 7.3 & $28 \%$ & $\begin{array}{l}\text { Texas, Oklahoma, Loutsiana are heavy users and pro- } \\
\text { ducers of riatural gas (gas is used for electric power } \\
\text { generation). Some efforts are being made to curtail } \\
\text { export to other states (challenged in court). }\end{array}$ \\
\hline Mounta in & 1.0 & $4 \%$ & $\begin{array}{l}\text { Colorado. Wyoming, New Mexico are concerned about } \\
\text { rapid mining developtient and environmental protection. } \\
\text { Energy resources in Arizona, Nevada are mostly under } \\
\text { federal or Indian control. Energy production in this } \\
\text { arid region will place heavy demands on scarce water } \\
\text { resources. }\end{array}$ \\
\hline Pactific & 2.4 & $9 \%$ & $\begin{array}{l}\text { California imports one half of its energy, generates } \\
\text { much electricity from petroleum and gas. } \\
\text { Hawaif's econamy is based on imported oil; it has } \\
\text { good potentfal for waste recycling, biomass use. } \\
\text { Washington and Oregon have hydro and wood resources. }\end{array}$ \\
\hline Puerto Rico & & . & $\begin{array}{l}\text { Economy developed on cheap imported ofl is now under. } \\
\text { extreme hardship from rising prices. No financial } \\
\text { resources are available for expensive alternative } \\
\text { energy development. }\end{array}$ \\
\hline TOTAL & 26.0 & $100 \%$ & 1975 data. \\
\hline
\end{tabular}

wood (biomass); In the petroleum Industry, ovar 90 percent of refinery process heat is generated by burning low-demand, low-cost (to the industry) residual heavy oils and gases. Therefore, even though it appears from Table 5 that a large part of industrlal process heat requirements is for low and medium-temperature process heat and theoretically suitable for solar applications, the real potential for SIPH 18 very much smaller due to a number of market factors and other barriers.

TABLE 5

Typical Energy Consumption for Industrial Process Heat by Industrial Group and Temperature Range, in Quads

\begin{tabular}{|lllllllll|l|}
\hline TEMP. RANGE $\mathrm{V}$ INUUSIKY & Metals & Chemicals & Petroleum & Paper & $\begin{array}{c}\text { Clay, Glass } \\
\text { and Stone }\end{array}$ & Food & Other & TOTAL \\
\hline Less than $212^{\circ} \mathrm{F}$ & 0.2 & 0.2 & - & 0.2 & - & 0.3 & 0.3 & 1.2 & $10 \%$ \\
$212^{\circ}-350^{\circ} \mathrm{F}$ & 0.05 & 1.05 & 0.2 & 1.1 & 0.1 & 0.4 & 0.6 & 3.5 & $29 \%$ \\
$350^{\circ}-550^{\circ} \mathrm{F}$ & 0.1 & 0.8 & 0.3 & 0.5 & - & 0.05 & 0.3 & 2.05 & $17 \%$ \\
$550^{\circ}-1100^{\circ} \mathrm{F}$ & 0.15 & 0.1 & 1.95 & - & - & - & 0.25 & 2.45 & $21 \%$ \\
Greater than $1100^{\circ} \mathrm{F}$ & $1.0^{*}$ & 0.1 & 0.4 & 0.1 & 1.0 & - & 0.1 & 2.7 & $23 \%$ \\
\hline TOTAL & 1.5 & 2.25 & 2.85 & 1.9 & 1.1 & 0.75 & 1.55 & 11.9 & $1000 \%$ \\
\hline
\end{tabular}

\#Excluding processes using metallurgic coal. 


\section{Potential of SIPH}

Figure 2 in the Executive Summary shows the consumption data of Table 5 plotted as a curve showing the percent of industrial process heat consumed versus the required temperature ranges. On the same graph, the operating temperatures of various SIPH collector technologies are also indicated (from Ref. 15). It would appear that almost 60 percent of industrial process heat could be supplied with commercially available SIPH technology today. However, this type of representation which has been rather widespread, gives a very misleading picture of the actual potential of SIPH. Figure 7 shows the data of Table 5 using the cumulative consumption figures in quads. A potential estimate of energy conservation for industrial process heat (especially through the use of cogeneration, cascading, heat recovery, and process efficiency improvements) is shown by the dotted line. Since the net effect of energy conservation is a move of the curve to the left, the potential of SIPH under these circumstances is severely diminished at process temperatures below $550^{\circ} \mathrm{F}$. A number of additional factors which act to reduce the potential of SIPH applications even further will be discussed later in this assessment.

FIGURE 7

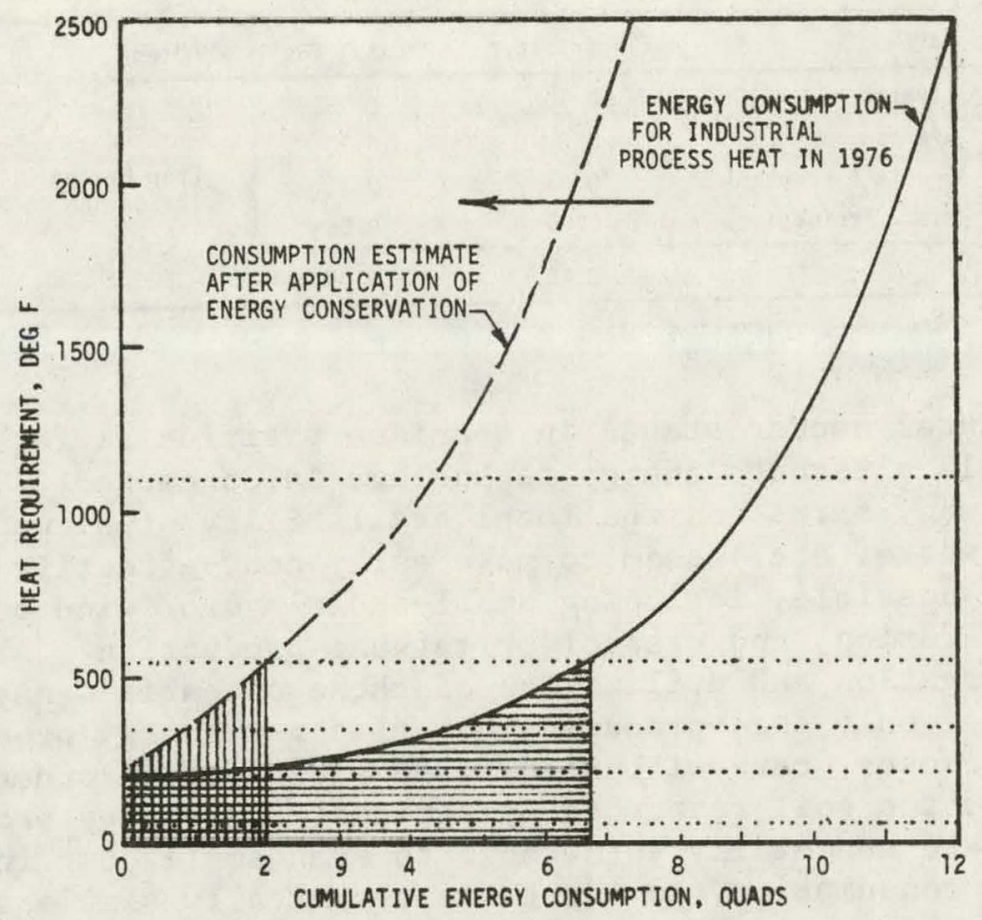

Cumulative Energy Consumption for Industrial Process

Heat and Potential of Energy Conservation for Different Process Heat Requirements

A recent assessment estimates the potential of SIPH to be less than $0.25 \mathrm{Q}$ by the year 2000 , even with relatively ambitious cost reductions (Ref. 18). The Domestic Policy Review of Solar Energy (Ref. 17) is rather optimistic at estimating this potential at 2.6 Q by the year 2000. About 1 in 7 factories would have to use some form of solar energy to achieve this goal, and 5.9 billion square feet of collectors (primarily of the concentrating 
type) would be required to supply the target $2.6 \mathrm{Q}$ (Ref. 5). With the present political climate and doubtful support for solar $R \& D$, it appears unlikely that favorable conditions will exist to even replace 0.25 Q of fossil energy with SIPH by the year 2000. If the ultimate goal (as recently stated by DOE) is the reduction in vulnerability of the U.S. to interruptions in imported crude oil supplies, then investment in energy conservation, cogeneration, and lower-cost alternate energy technology may be more effective in achieving this end than allocating large amounts of funds to SIPH development (Ref. 16).

\section{Agriculture}

The agricultural sector accounts for less than two percent of U.S. energy consumption, not including about $1.6 \mathrm{Q}$ for energy feedstocks in fertilizers and pesticides, $0.5 \mathrm{Q}$ for farm vehicle fuel consumption and transportation to markets) and $0.2 \mathrm{Q}$ for energy input in the fabrication of farm machinery. Table 6 from Reference 11 summarizes agricultural energy. use.

TABLE 6

U.S. Agricultural Energy Use, in Quads (1974 hata)

\begin{tabular}{|c|c|c|c|}
\hline TYPE & Electricity* & Fossil Fuel & Notes \\
\hline Livestock & 0.15 & 0.15 & \multirow{5}{*}{$\begin{array}{ll}\text { Crop Drying } & 0.1 \\
\text { Irrigation } & 0.25\end{array}$} \\
\hline Grains & 0.2 & 0.75 & \\
\hline Fruits \& Vegetables & 0.05 & 0.1 & \\
\hline Misc. Irrigation & 0.05 & 0.05 & \\
\hline TOTAL & 0.45 & 1.05 & \\
\hline
\end{tabular}

*Including generation losses

The agricultural sector stands in a unique position as far as application of smal1-scale alternate energy technology is concerned. The remote location of many farms and the local avallability of biomass (livestock waste, crop waste, etc.) seem to make early cost-effective application of such methods possible, including small-scale hydro, wind pumping and wind electric generation, and ethanol or methane production. Attention to energy conservation and utilization of these potentials may ultimately make farms not only food-producing but also net energy producers. At the same time, however, care will need to be exercised in order not to deplete the water and top soll resources by agricultural energy production. Since farms are especially vulnerable to even small cost increases in their energy consumption, low-cost and technically simple alternate technology would seem to offer preferable (or the only possible) solutions to the energy problem in agriculture, and high-technology, highcost SIPH applications would be precluded on this score alone, especlally on a global scale. The needs in the agricultural sector are primarily for low-temperature heat for grain drying, greenhouse heating, and water heating which can in many cases be met by site-built flat plate solar collector systems. Appropriate technology developments in agriculture also represent an eminently suitable product for export to developing countries and should thus be supported, even though the quantitative energy savings may not be very large in each farm application. The benefits worldwide, however, could be enormous. 


\section{SIPH TECHNOLOGY ASSESSMENT}

The objective of this section is to review the technical and performance characteristics of solar industrial process heat (SIPH) plants and equipment, as well as to evaluate how the operating experience of over a dozen SIPH demonstration projects is influencing institutional acceptance and economic projections.

\section{A. SIPH Systems and Components}

The basic components of a SIPH system are similar to those of a hot water or hot air solar system. They are: solar collectors, tracking mechanisms, plumbing (or ducting), pumps (or blowers), controls, valves, storage, and heat exchangers. The requirement for durable and reliable equipment in the case of residential applications is very important, but for industrial applications, it is crucial. Thus it is necessary that SIPH systems have (1) highly reflective, durable mirrors for the concentrators, (2) absorbers with high absorptivity, low emissivity, and low heat loss, (3) simple, durable and reliable tracking mechanisms, and (4) flexible couplings that can withstand high temperatures, pressures, and rotation with flowing fluid. If solar industrial process heat hopes to gain a market, then this SIPH equipment must conform to the durability and reliability standards expected and obtained by industry for their other operating equipment. All collectors currently being used in SIPH applications require additional R \& D to improve durability, reliability, efficiency and to substantially reduce cost (Ref. 19).

A variety of SIPH system designs are possible, depending on the service required and the process temperatures needed. Figures 8 through 13 give simplified diagrams of different types of SIPH systems. Figure 8 (from Ref. 20) represents a flash boller process steam system where water under high pressure is circulated directly through the collectors and throttled down before going into the boiler. The water flashes into steam in the boiler and is then used as process steam. The Johnson and Johnson plant in Sherman, Texas, utilizes such a system. Figure 9 (from Ref. 21) 11lustrates a process steam generator system. A freeze-resistant heat transfer fluid circulates through the collectors and through a heat exchanger in the boller to produce steam. An accumulator tank is installed in the fluid loop to serve as expansion tank as well as a dump tank. The fluid loop contains anti-freeze fluids so that freeze protection is not required. The Dow Chemical plant in Dalton, Georgia, utilizes this type of system.

When the output is process hot water instead of process steam, a heat transfer fluid such as a water/ethylene-glycol mixture flows through the collector field and circulates through a heat exchanger, as shown in Figure 10. Such a system is being used at the York Building. Products Company in Harrisburg, Pennsylvania. A variation of this system (drawn schematically in Figure 11) produces process hot air by using a 1iquid-toair heat exhanger instead of a liquid-to-liquid heat exchanger. An example of such a system is at the Gilroy Foods plant in Gilroy, California. Figure 12 shows a direct process hot air system where hot air is circulated directly to the end-use point. This is the simplest type of system and judging from operating experfence with such systems at the Gold Kist 


\section{FIGURE 8}

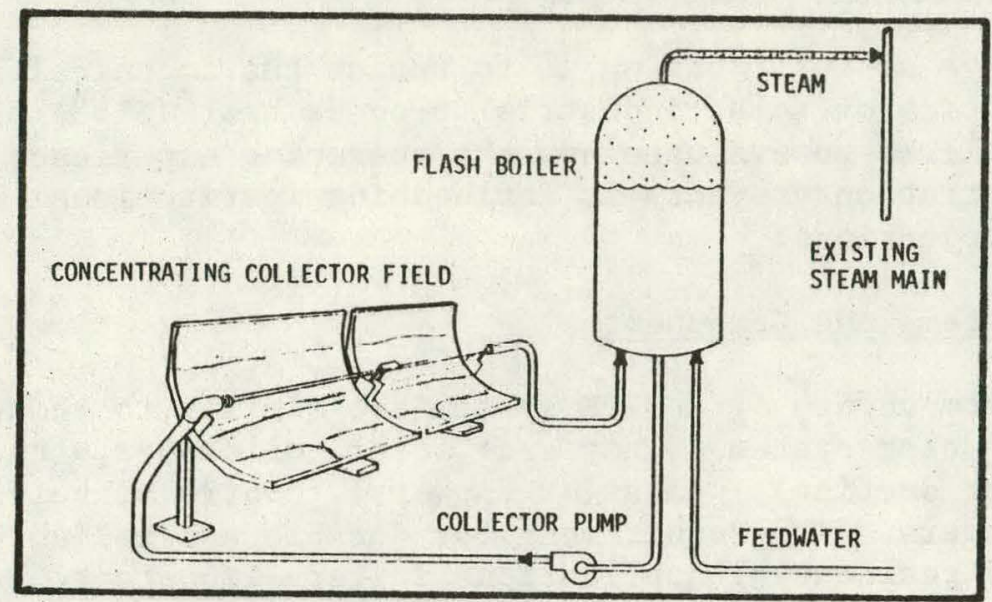

Process Steam Flash Boller System

FIGURE 9

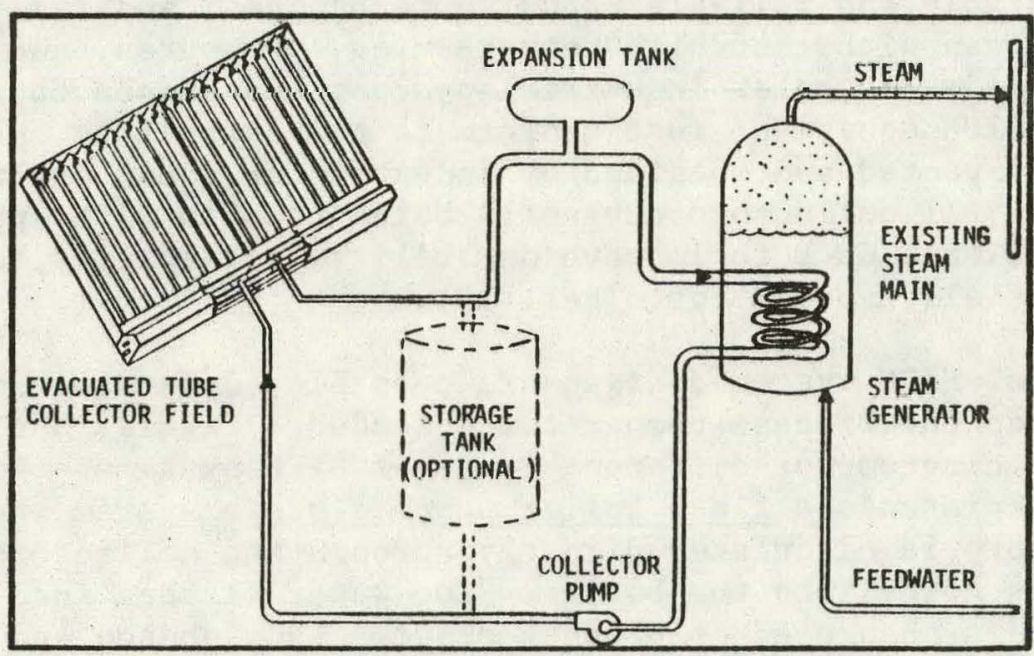

Process Steam Generation System

FIGURE 10

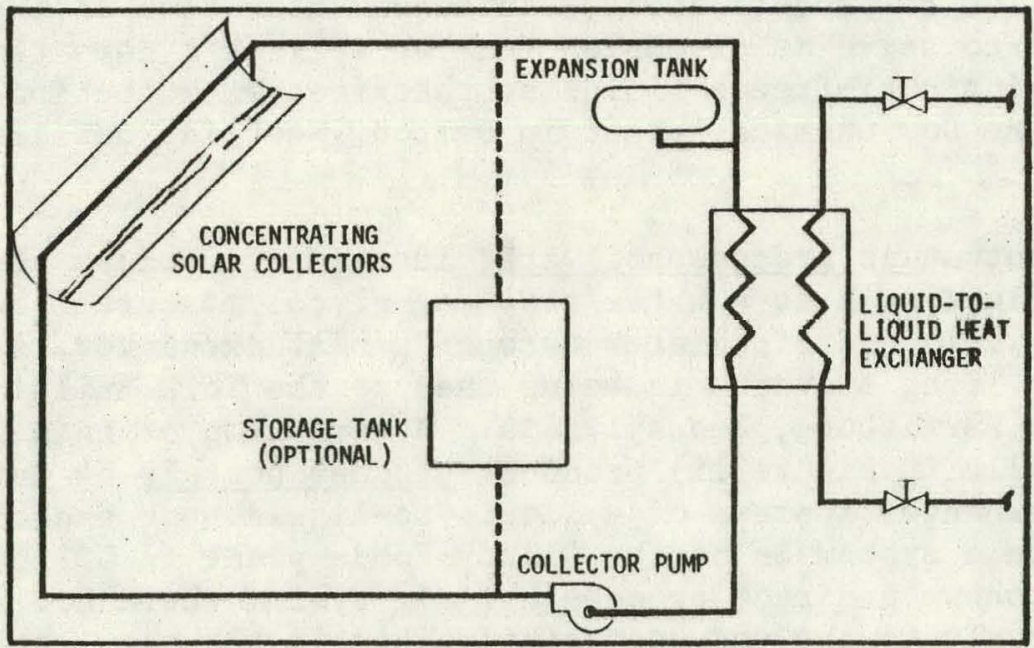

Process Hot Water System 
FIGURE 11

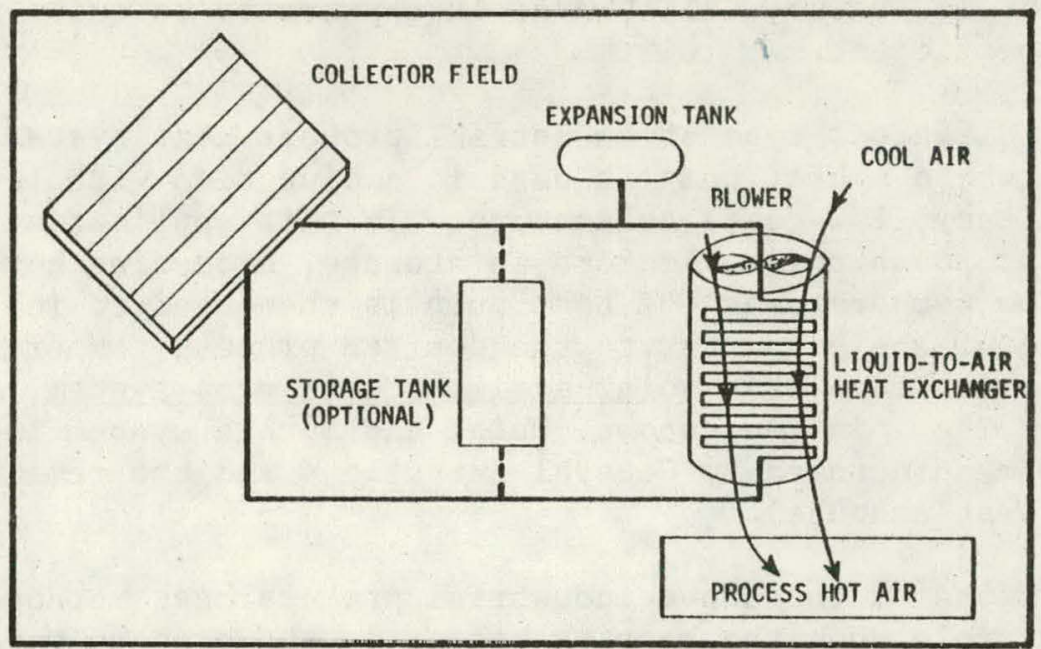

Liquid Collector/Process Hot Air System

FIGURE 12

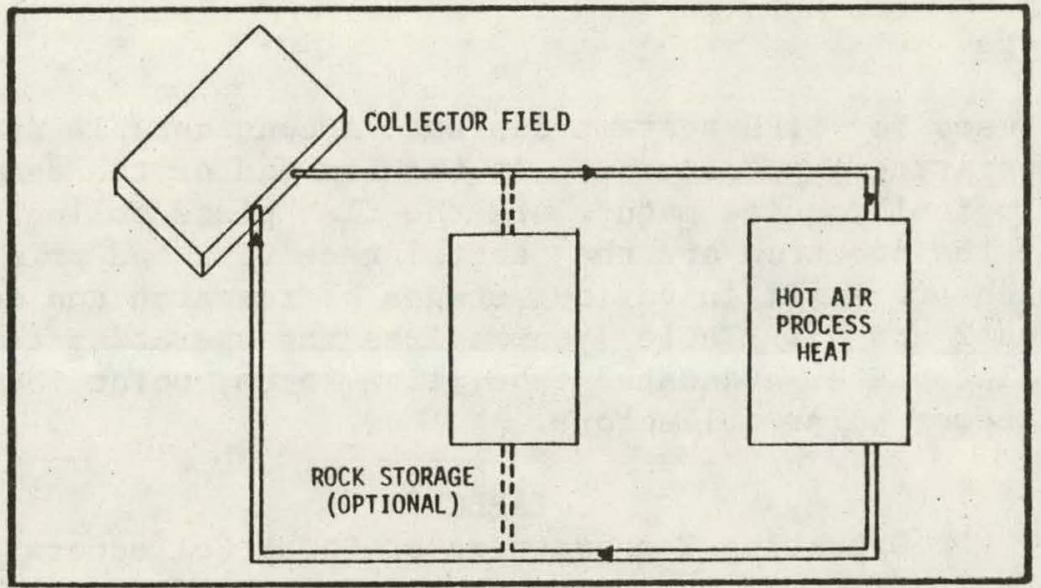

Direct Process Hot Alr System

FIGURE 13

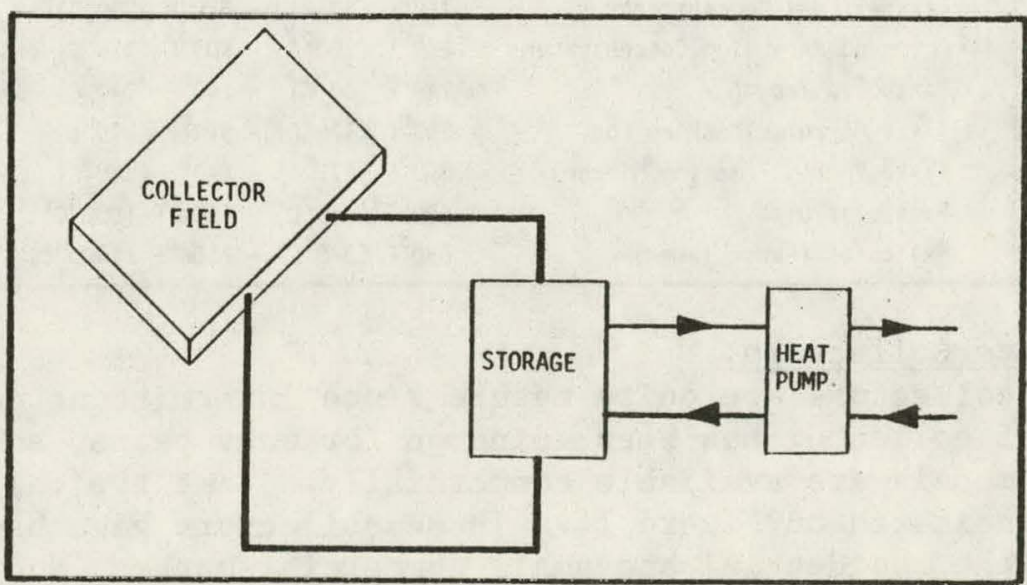

Solar-Assisted Heat Pump System 
operation in Decatur, Alabama, and the Lamanuzzi and Pantaleo Foods drying plant in Fresno, California, it appears to be quite reliable and reasonably efficient.

A slightly different type of industrial process heat system is shown in Figure 13, where a heat pump is used in conjunction with low temperature (low efficiency, low cost) collectors. In this application, a liquid is circulated through the collectors to storage, producing hot water at relatively low temperatures. A heat pump is then used to increase the temperature of the hot water to the desired process temperature. This is very similar to a HVAC solar-assisted heat pump system, and General Extrusions, Inc. In Youngstown, Ohio, has such a system installed (with collectors manufactured by General Extrusions and the remainder of the system by Westinghouse).

Some variations of the above industrial process heat methods are being used for example when the heat exchanger is the process material itself, as is the case at the SIPH installation at the Riegel Textile Corporation in LaFrance, South Carolina. Other possible system arrangements can be deduced from Figure 3.

\section{Collectors}

Collectors used for SIPH systems can span a considerable spectrum in terms of operating temperatures. At the low end of the temperature scale and technologically quite mature are the flat plate collectors. At the high end of the spectrum are the central receivers and point focus receivers which are still in various stages of research and development (see Figures 2 and 3 ). Table 7 summarizes the operating temperature ranges of flat plate, evacuated tube, line focus, point focus and heliostat/power tower solar collectors.

TABLE 7

Operating Temperatures of Solar Collectors

\begin{tabular}{|ll|}
\hline COLLECTOR TYPE & TEMPERATURE RANGE \\
\hline Flat Plate & $120^{\circ} \mathrm{F}\left(50^{\circ} \mathrm{C}\right)-200^{\circ} \mathrm{F}\left(95^{\circ} \mathrm{C}\right)$ \\
Evacuated Tube & $120^{\circ} \mathrm{F}\left(50^{\circ} \mathrm{C}\right)-350^{\circ} \mathrm{F}\left(175^{\circ} \mathrm{C}\right)$ \\
Fresnel Lens Concentrator & $140^{\circ} \mathrm{F}\left(60^{\circ} \mathrm{C}\right)-570^{\circ} \mathrm{F}\left(300^{\circ} \mathrm{C}\right)$ \\
Compound Parabolic Concentrator & $300^{\circ} \mathrm{F}\left(150^{\circ} \mathrm{C}\right)-600^{\circ} \mathrm{F}\left(315^{\circ} \mathrm{C}\right)$ est. \\
Parabolic Trough & $140^{\circ} \mathrm{F}\left(60^{\circ} \mathrm{C}\right)-640^{\circ} \mathrm{F}\left(340^{\circ} \mathrm{C}\right)$ \\
Fixed Mirror, Tracking Focus & $350^{\circ} \mathrm{F}\left(175^{\circ} \mathrm{C}\right)-590^{\circ} \mathrm{F}\left(310^{\circ} \mathrm{C}\right)$ \\
Fixed Focus, Tracking Mirror & $350^{\circ} \mathrm{F}\left(175^{\circ} \mathrm{C}\right)-640^{\circ} \mathrm{F}\left(340^{\circ} \mathrm{C}\right)$ \\
Parabolic Dish & $500^{\circ} \mathrm{F}\left(260^{\circ} \mathrm{C}\right)-1500^{\circ} \mathrm{F}\left(800^{\circ} \mathrm{C}\right)$ \\
Heliostat (Power Tower) & $650^{\circ} \mathrm{F}\left(345^{\circ} \mathrm{C}\right)-2500^{\circ} \mathrm{F}\left(1400^{\circ} \mathrm{C}\right)$ \\
\hline
\end{tabular}

\section{a. Flat Plate Collectors:}

Flat plate collectors are quite mature since intermittent development of this type of collector has been going on for many years, and a large variety of models are available commercially. Some typical arrangements have been indicated on Figure 14. These collectors have been developed mostly for the residential and small commerclal market, and the small unit size may not be sultable to large industrial applications. The cost of these collectors has not decreased in the last five years contrary to 
expectations but instead has risen steadily. Price reductions in the future are unlikely since most of the materials as well as labor costs are increasing. Presently, there are no uniform standards for determining performance that include the most important factors -- durability and reliability. Modifications to ASHRAE 93-77 standards are now being used to measure thermal performance, and a few additional tests such as 30-day stagnation, thermal shock, cold fill (for liquid collectors), followed by disassembly, could help to weed out some of the lower-quality collectors. The newly-founded Solar Rating and Certification Corporation could help in establishing some nationwide uniform standards and establish consumer confidence. Corrosion leaks in 1iquid collectors are still problem areas, and glazing degradation is quite common in industrial environments.

\section{FIGURE 14}

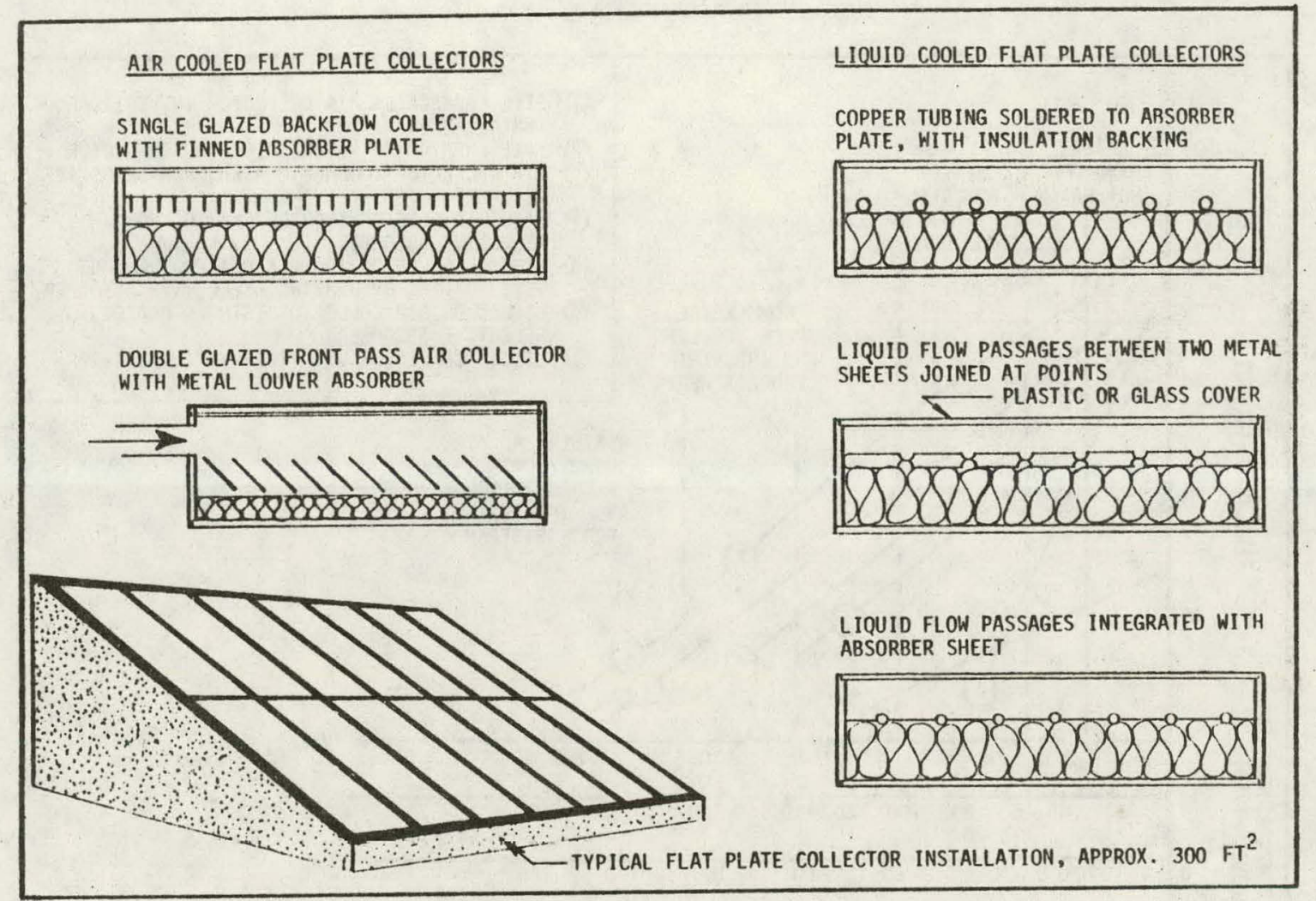

Typical Flat Plate Solar Collectors

The glazing material used most often for flat plate collectors is tempered glass, and the problem with glass is its weight when roof-top or other above-ground installation is considered. In one location (Red Star Industrial Service, Fresno, California) plastic glazing had to be used because the roof could not hold glass-covered collectors. After one year of operation, the plastic suffered severe degradation due to UV radiation. It was replaced by mylar sheets which also are beginning to deteriorate (creeping). Many other facilities using plastic glazing are having degradation problems also after a very few years of operation. Plastics are subject to cracking, warping, scratching, and decreased transmissivity. 
Flow in flat plate air collectors is quite well understood, and operational experience is extensive. The advantages of air collectors over liquid collectors are well known and include: no corrosion, no freezing problems, no serious leaks. However, one disadvantage especially in industrial heat applications where long duct runs are frequently necessary is that large parasitic power input is required to operate the system. Air ducts also need a certain amount of space and must be we11-insulated.

Figure 15 (from Ref. 3) gives examples of the efficlency range of various flat plate collectors and different applications. The temperature difference $\Delta T$ is the difference between the operating temperature of the collector and ambient temperature. It can be seen that the collectors with reasonably high efficiency are at the lower limit of suitability for industrial process heat applications.

\section{FIGURE 15}

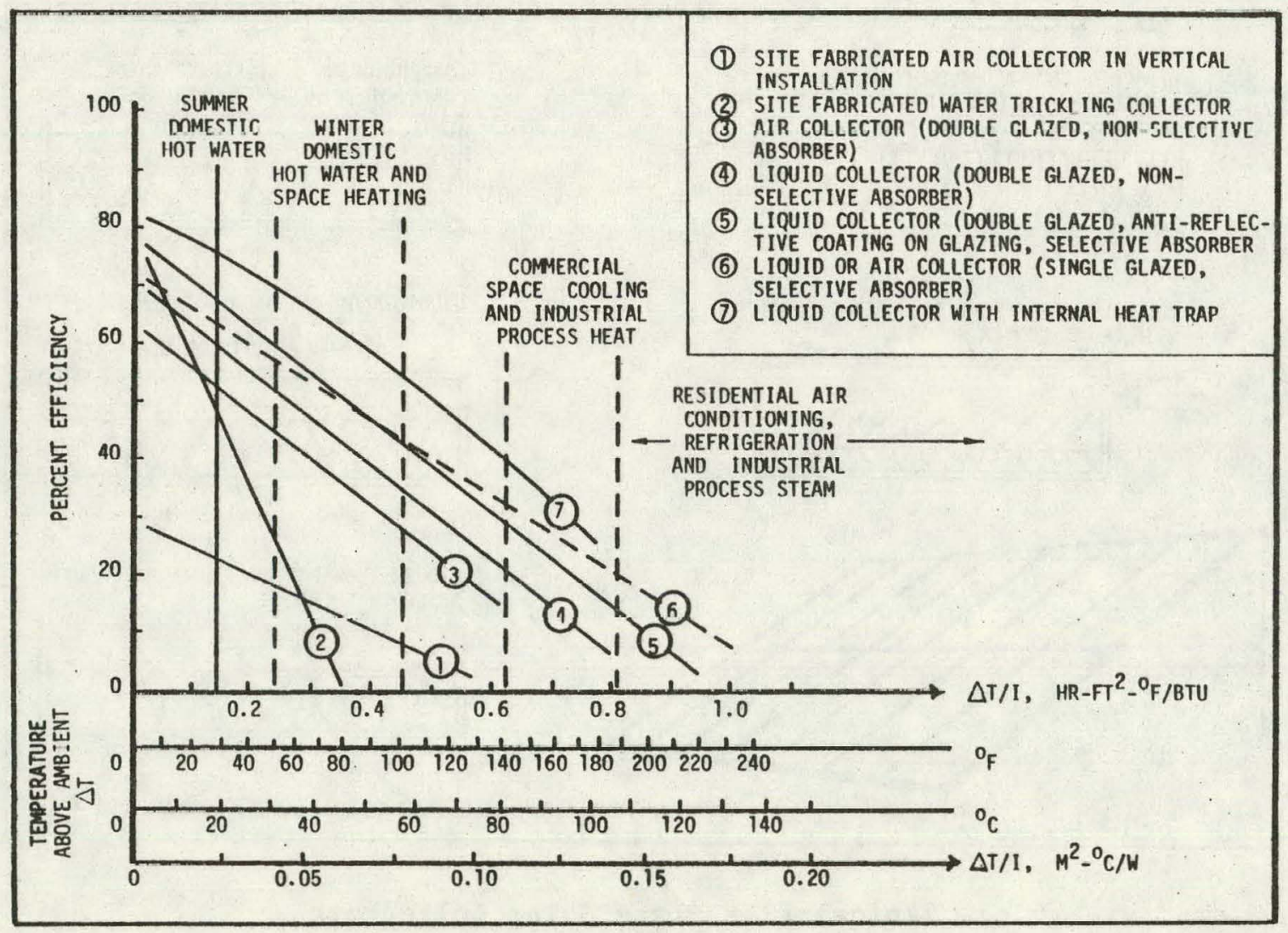

\section{Application and Efficlency Range of Varlous Flat Plate Collectors}

\section{b. Evacuated Tube Solar Collectors:}

Evacuated tube collectors as illustrated on Figure 16 (from Ref. 22) generally consist of the absorber tube enclosed by a transparent cover, and conduction and convection losses are minimized by a vacuum between the absorber and the transparent cover. Field operational experience with evacuated tubes are still limited, although a number of systems have been installed in the last four years. There have been many failures of 


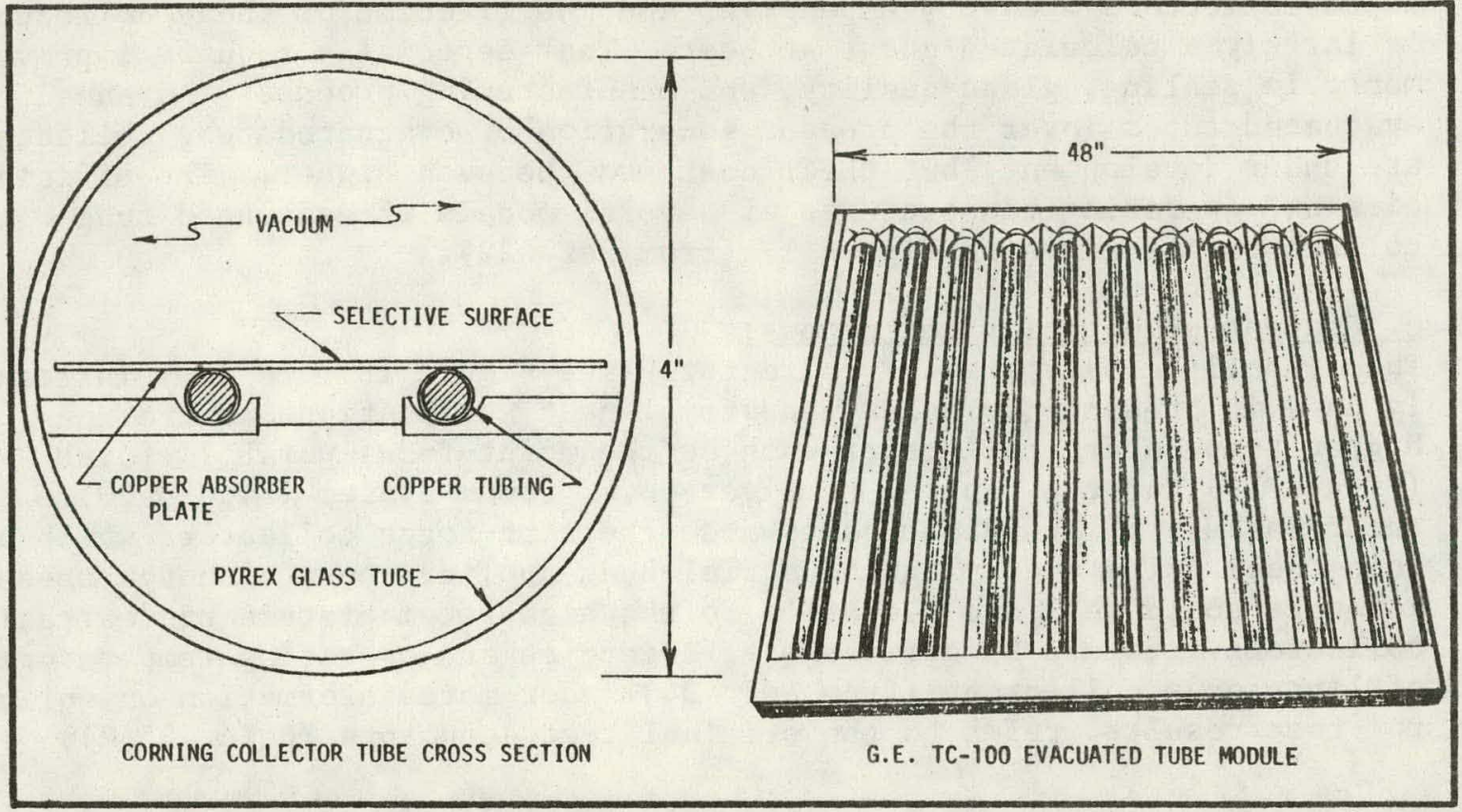

Typical Evacuated Tube Solar Collector

FIGURE 17

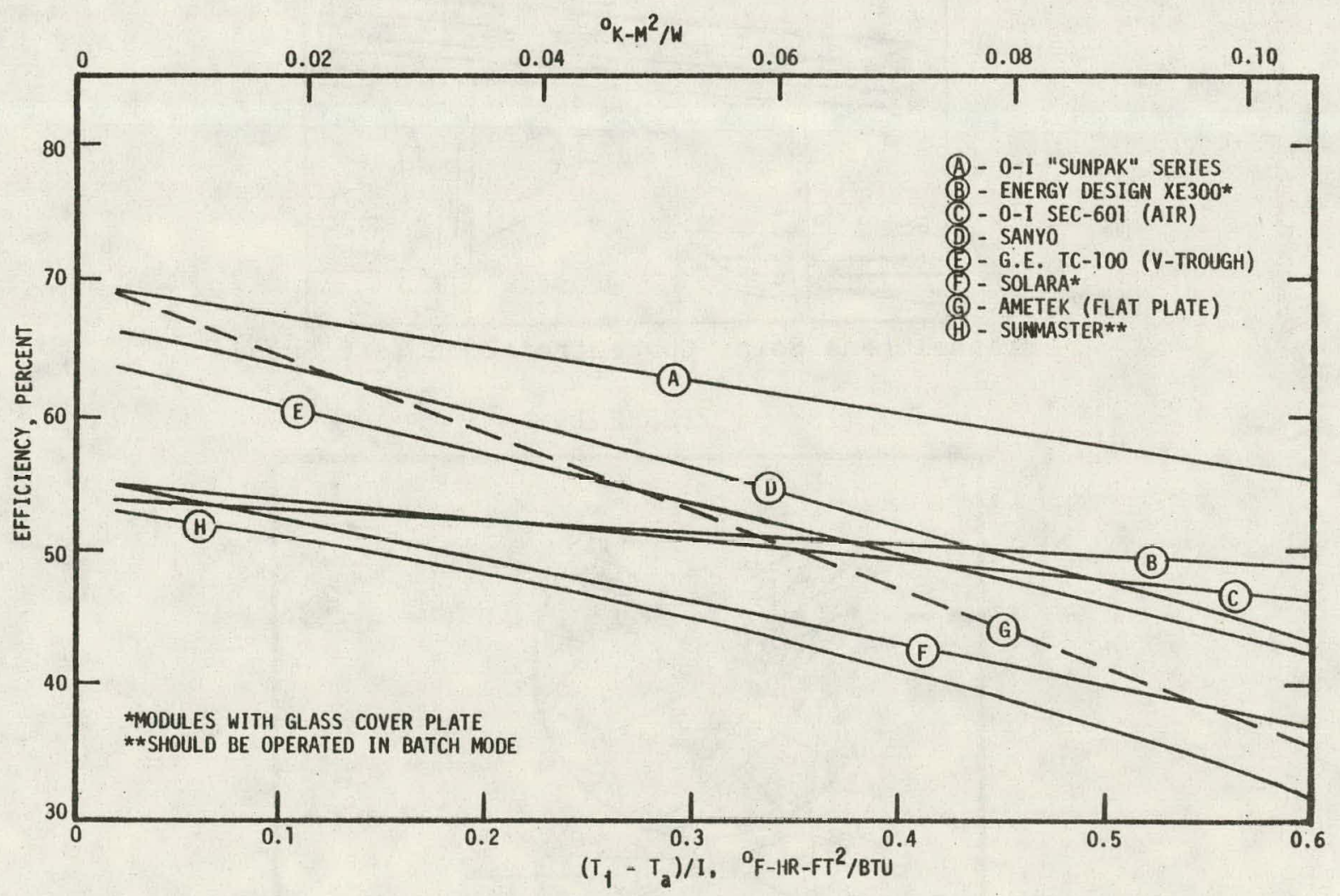

Comparison of the Efficiencies of Varlous Evacuated Tube Collectors with a Double Glazed, Selectively-Coated Flat Plate Collector 
evacuated tubes due to stagnation caused by a coolant flow interruption. These collectors are very expensive, and the lifetime of these collectors is largely a calculated guess at best. They especially require improvements in sealing, glass quality, and manufacturing process. Advanced evacuated tubes (over the present generation of evacuated tube collectors) are under development, but their cost may be even higher. The efficiencies and operating temperatures of several models of evacuated tube collectors are given in Figure 17 (from Ref. 22).

\section{c. Concentrating Solar Collectors:}

The fresnel lens type solar collectors (see Figure 18) are only infrequent1y used in present-day solar industrial heat applications as are the higher temperature collectors such as the point-focus parabolic dish (Figure 19) and the central receiver power tower system (Figure 20). Thus the remarks here are directed towards the line-focus collectors which are being used quite widely in industrial heat applications, although these comments could well apply equally to the higher temperature concentrating collectors. Figure 21 gives the efficiencies and operating temperatures of line-focus collectors (from Ref. 24). For more information on collector test results, refer to the original test documents (Refs. 23,24).

FIGURE 18

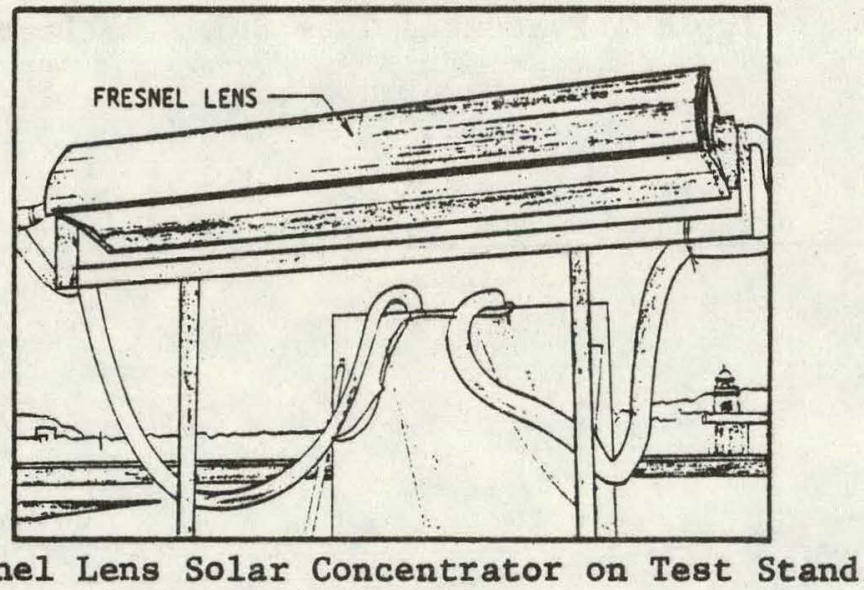

FIGURE 19

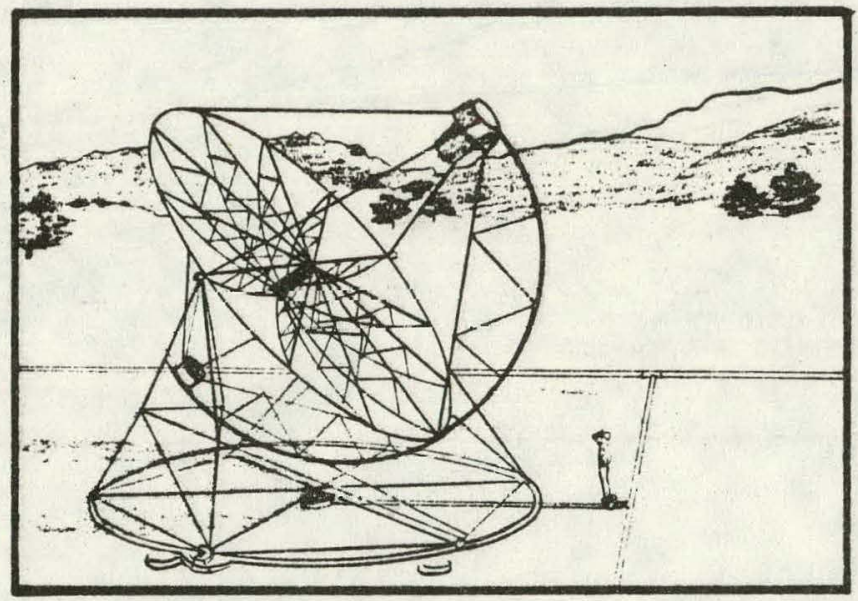

Parabolic Dish Point Focus Solar Collector 


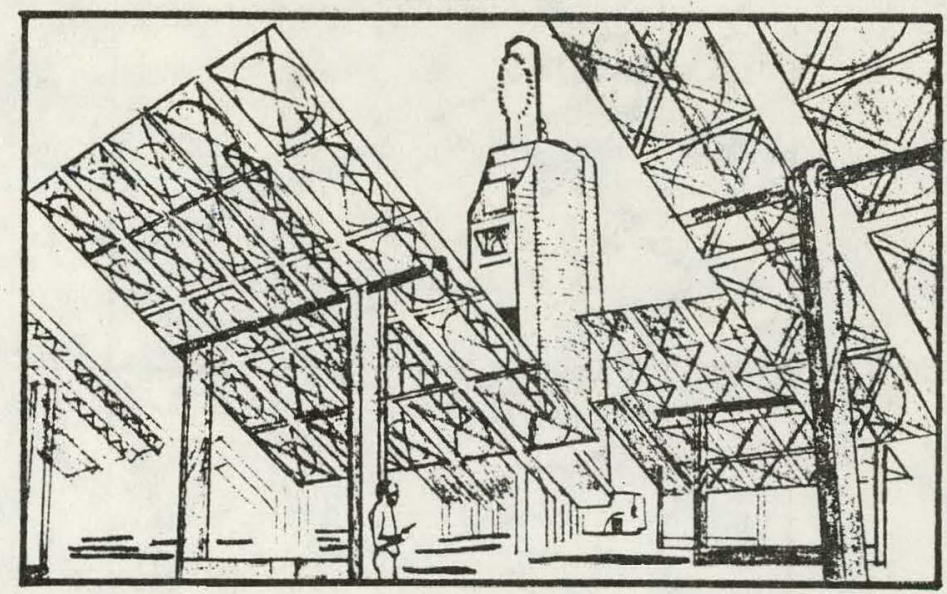

Hellostat/Power Tower Central Recelver System

FIGURE 21

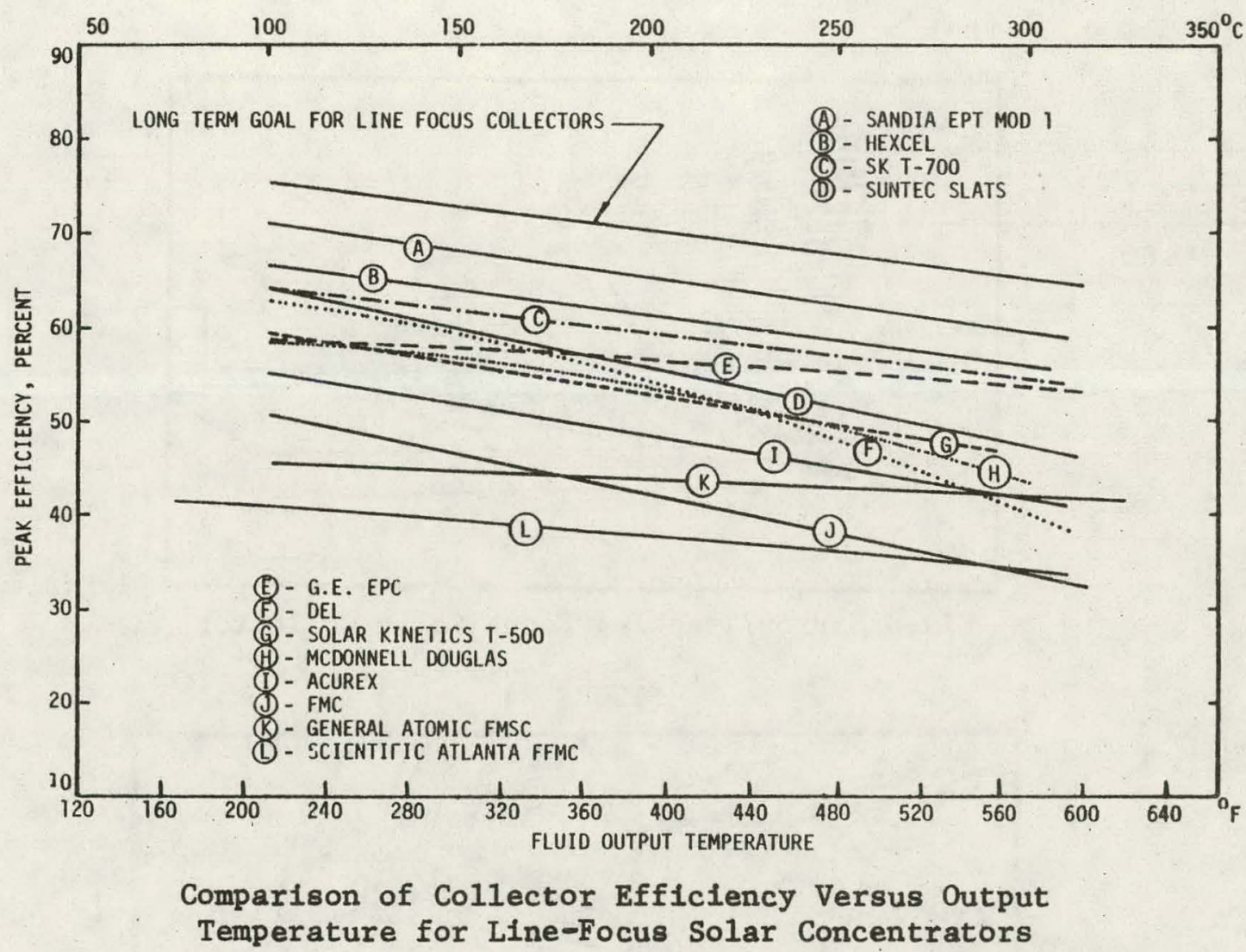

Figures 22,23,24 show typical line-focus collector types (parabolic trough, fixed mirror/tracking focus and fixed focus/tracking mirror, respectively). The parabolic trough concentrator has been used in a number of SIPH demonstration projects. Figure 25 shows a comparison of thermal efficiencies of the parabolic dish, the line-focus and the evacuated tube collectors (from Ref. 25). It is quite obvious that for high temperature applications (such as cogeneration), the parabolic dish holds a great deal of promise. The compound parabolic concentrator (CPC) is only in the early 


\section{FIGURE 22}

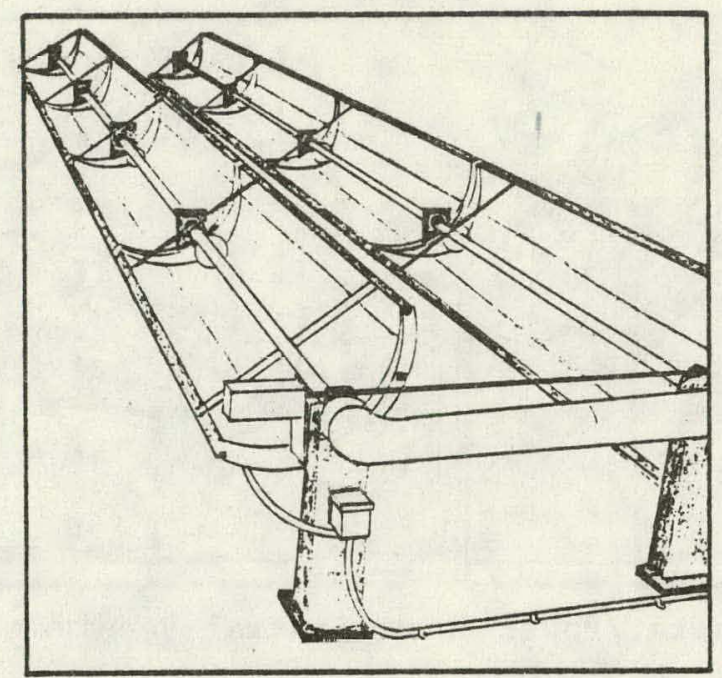

Parabollc Trough Solar Collector

FIGURE 23

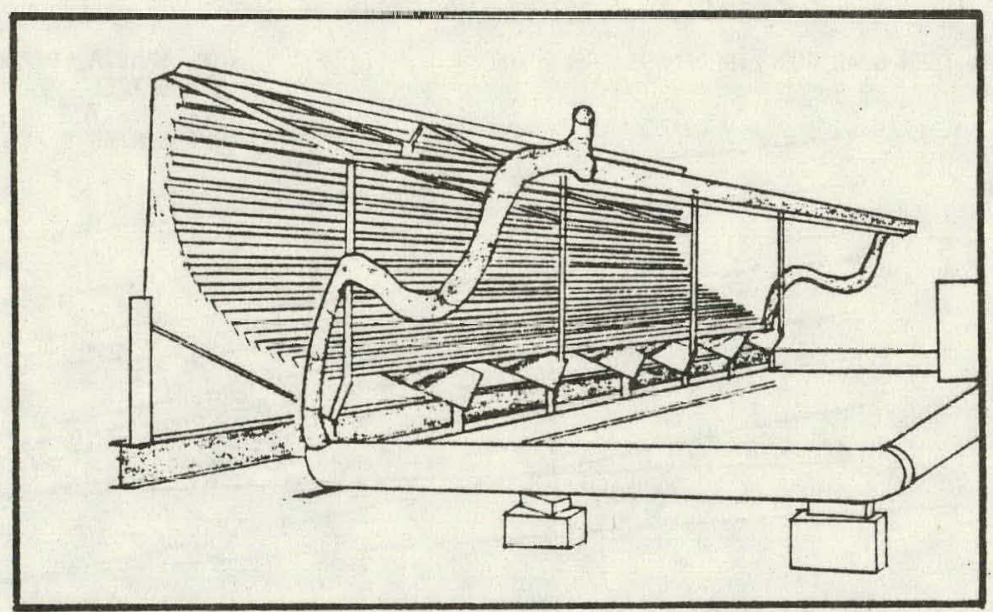

Fixed Mirror/Tracking Focus Solar Collector

FIGURE 24

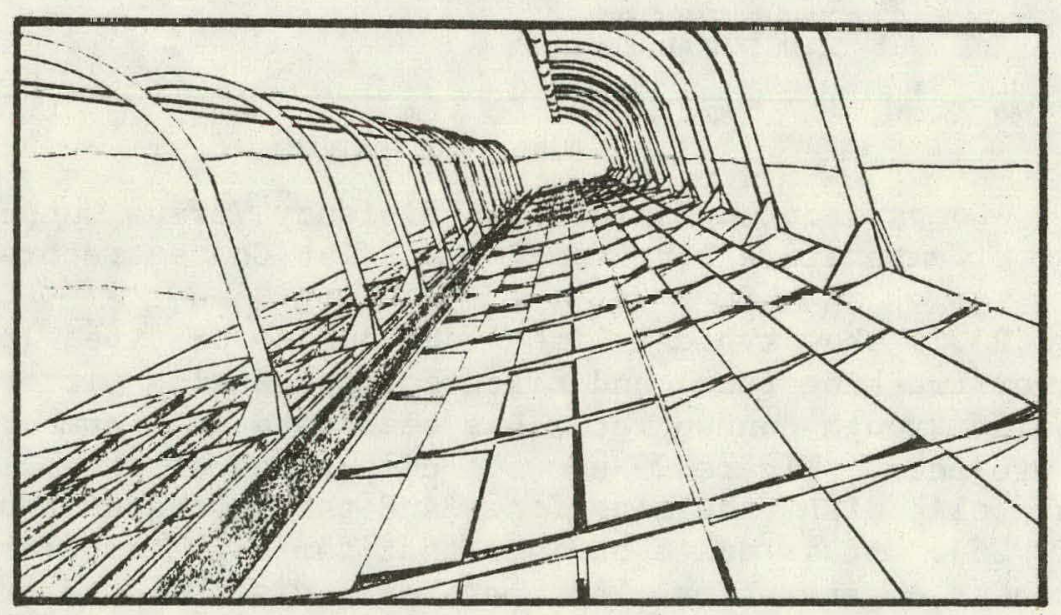

Fixed Focus/Tracking Mirror Solar Collector 
FIGURE 25

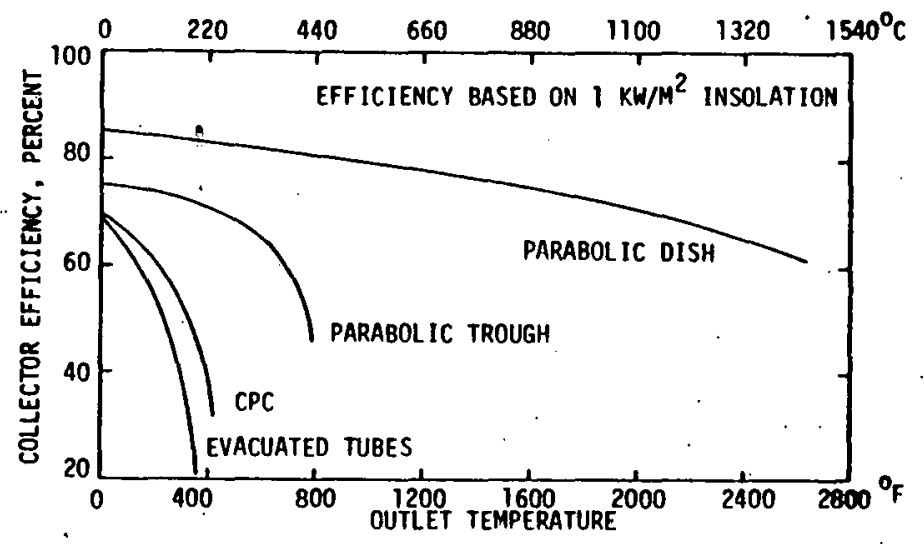

Comparison of Peak Efficlency for Medlum-Temperature Solar Collectors

stages of development and has not yet been applied in a large-scale fleld experiment. Important components to satisfactory performance of line-focus collectors are the reflective surface, the selective absorber coating, and sealants.

Reflective Surface: The reflective surface is the essential component in malntalning high efficiency in concentrating collectors. The reflector consists of the reflective surface, the protective coating and the backing which protects the backside of the reflective surface. Table 10 taken from Reference 19 summarizes the evaluation of three types of reflector materials. Field experience shows that deterioration of metal type reflective surfaces due to exposure to industrial environments is common. Plastics weather very badly. In climatic conditions such as are encountered in the U.S. Southwest where high levels of insolation occur, UV degradation and abrasion due to sand and dew are still problems. Cleaning with anti-static liquids is required because of the affinity of plastic for dust. Thus, despite the potential low cost, plastics are not

TABLE 8

Evaluation of Candidate Reflector Materlals

\begin{tabular}{|c|c|c|c|}
\hline TYPE MATERIALS & AUVANTAGES & DISADVANTAGES & COMMENTS \\
\hline $\begin{array}{l}\text { Pol Ished Metal: } \\
\text { Brightened metal with } \\
\text { protective coating. }\end{array}$ & $\begin{array}{l}\text { Low cost, durable mate- } \\
\text { rial. established in } \\
\text { other applications. No } \\
\text { manufacturing problems. } \\
\text { Low initial reflectivity. } \\
\text { Easily replaced. light } \\
\text { weight. }\end{array}$ & $\begin{array}{l}\text { Protective coating (oxide) } \\
\text { reduces reflectivity to } \\
80 \text { percent. }\end{array}$ & $\begin{array}{l}\text { Improvement in existing } \\
\text { technologies is not ex- } \\
\text { pected. } \\
\\
\text {.. }\end{array}$ \\
\hline $\begin{array}{l}\text { Silvered Glass: } \\
\text { Protective glass } \\
\text { factng, silvered re- } \\
\text { flective surface. } \\
\text { coated verso. }\end{array}$ & $\begin{array}{l}\text { High reflectivity ( } 95 \\
\text { percent). Resistant to } \\
\text { scratching. Stays clean } \\
\text { longer; easy to clean. }\end{array}$ & $\begin{array}{l}\text { Breakable/ silvering tends } \\
\text { to degrade. Heavy if } \\
\text { sagged glass is used. Thin } \\
\text { plate glass is difficult } \\
\text { to handle. }\end{array}$ & $\begin{array}{l}\text { Has best qualities of } \\
\text { candfdate materials con- } \\
\text { sidered. } \\
\qquad .\end{array}$ \\
\hline $\begin{array}{l}\text { Aluminized Plastics: } \\
\text { Teflon, modifled } \\
\text { acrylics. }\end{array}$ & $\begin{array}{l}\text { Low cost, light weight, } \\
\text { easy to work with. } \\
\text { Vapor deposit on film } \\
\text { protected by coating. } \\
\text {. }\end{array}$ & $\begin{array}{l}\text { Highly subject to abrastion. } \\
\text { Hard to clean effectively. } \\
\text { Dust is attracted to sur- } \\
\text { face. No present plastics } \\
\text { seem to be able to provide } \\
\text { better durability. }\end{array}$ & $\begin{array}{l}\text { Metallzed Tefion can be } \\
\text { severely degraded by en- } \\
\text { vironment. Modified acry- } \\
\text { lics have harder surface } \\
\text { and look most promising } \\
\text { for plastic reflectors. }\end{array}$ \\
\hline
\end{tabular}


recommended for reflectors in industrial applications. Glass reflectors (such as in the SIPH system at the. Home Laundry in Pasadena, California) are generally expensive, but they do eliminate most of the objections to the plastics. Corrosion of the metal coating from molsture, the additional weight, and the high cost are some of the major drawbacks of glass reflectors.

Selective Absorber: For the temperatures and efficiencies required in industry, the absorber surface (plate for a flat plate collector and steel pipe for line-focus collectors) should be coated with a selective coating. Typical absorptances of 0.9 to 0.95 and emittances of 0.05 to 0.1 can be achleved. Black chrome is obtained by electroplating chrome oxide over a reflectlve nickel coating. Although black chrome has been found to be durable and efficlent at low temperatures, peeling has occurred in field operations at high temperatures. Durability of selective absorber surfaces is still relatively unknown. In dirty industrial environments coupled with high humidity and high temperature operation, rapid deterforation of selective absorber surfaces has been observed. Another type of selective surface is black cobalt which seems to perform well at high temperatures. This selective surface is still in the developmental stage and will require more field experience and testing before its commerclal values are known. The absorbers of 1ine-focus collectors are frequently enclosed by a Pyrex glass sleeve in order to minimize excessive radiation and convection losses due to high operating temperatures. This can also help the selectlve absorber coating to weather better, expeclally if the space between the absorber and glass is partially evacuated.

Sealents: For low temperature applications, silicone appears to be a good sealant (up to about $300^{\circ} \mathrm{F}$ or $150^{\circ} \mathrm{C}$ ). Ethylene hydroxyl polymer can withstand higher temperatures. It is being produced in small quantities only and has relatively little fleld experience with collector use. However, sealants have not been a major problem in fleld applications. In order to seal against rain and dust, conventional sealants of various types have been used in the SIPH demonstration projects.

\section{d. Solar Ponds:}

According to Reference 26, solar ponds have the potential to displace from one to six quads of fossil fuel energy in low-temperature or preheating applications in non-urban areas. In the U.S., there are at present no SIPH applications of solar ponds, and there is no working experfence data for cost estimates. There are two basic types of solar ponds, the shallow solar pond and the salt-gradient non-convecting pond. Ponds differ from other types of collectors in that the water is not moving past an absorbing surface and also the water provides dafily or seasunal thermal storage. DUE has funded some solar pond research profects. Problems discovered with these small salt-gradient ponds were low efflclency (less than 10 percent), wind-blown debris, leaks, algaes, and salt precipitation. One planned SIPH shallow pond demonstration project at the Sohto Petroleum Company in Grants, New Mexico, was abandoned when construction costs proved to be too high. A second, much smaller, project at Sweet Sue Kitchens in Athens, Alabama, was cancelled by DOE due to economics (Ref. 21). Israel's $7000 \mathrm{~m}^{2}$ solar pond at Ein Bokek on the Dead Sea has recently begun generating $150 \mathrm{~kW}$ of electricity. In a 
cooperative program with Israel, the feasibility of using the Salton Sea in California's Impertal Valley is belng studled. Plans call for a 5 MW plant to come on line in 1984 (Ref. 27).

Solar pond applications for SIPH will be constrained by a number of barriers: large land use requirements, sufficient water and brine availability, cheap sources of salt, salt pollution, appropriate soll conditions, favorable climatic conditions, and efficiency and economics. These constraints make the solar pond practlcally unsuitable for urban areas. On the other hand, using naturally saline water for electric generation appears to be promising and appropriate; for instance, the Salton Sea project is expected to improve environmental conditions for fish and waterfow 1 by reducing salinity in large parts of the lake: Deep salt-gradient pond installations may require several years to reach steady state operating conditions; therefore, a number of years. will be required to evaluate the performance of solar ponds being built now. In the near term, $R \& D$ into solar ponds should be continued; solar ponds may in certain applications be more economical than large parabolic trough collector systems and thus should remain one of the options to be considered as a supply for industrial heat (after cost-effective methods of energy conservation have been implemented).

\section{Solar Trackers and Drtve Mechanisms}

Flat plate collectors, evacuated tubes and compound parabollc collectors do not use tracking mechanisms except for some manual seasonal adjustment. In general, low concentration ratio devices do not use tracking methods because they would not be cost-effectlve. Parabolic trough collectors as well as other high concentration ratio collector systems use tracking and drive mechanisms. Sun tracking is normally done by (1) shadow band detector, (2) computer tracking, (3) aperture tracking, or (4) a combination of computer and aperture tracking.

The shadow band method is based on the use of two photocell sensors placed on either side of a shading device. If one photocell receives more light than the other, the concentrator will be moved to bring the power output of the two cells back to equilibrlum. Thus the collector is aligned to the high intensity point in the sky. However, this type of tracker, a1though relatively inexpensive, has poor tracking accuracy, sometimes falsely locks in on clouds or bulldings, and has maintenance problems because of dirt accumulation. Differential amplifiers also tend to drift. Computer tracking is programmed to track the sun based on its theoretical position. Aperture tracking utilizes a heat flux sensor which is located at the absorber tube. The collector 1 s positioned such that it maximizes the thermal output of the heat flux sensor. The fine wire around the absorber tube also integrates the flux distribution down the absorber thus providing the best average position for the collector. Figure 26 shows the current tracking method which combines computer tracking with aperture tracking (from Ref. 28). The heat flux sensor acts to override the clock system in order to position the collector for maximum flux. Ceramic is used to insulate the silver-plated heat flux wire. Obtaining an accurate, reliable and durable tracking system at reasonable cost is still a problem. 


\section{FIGURE 26}

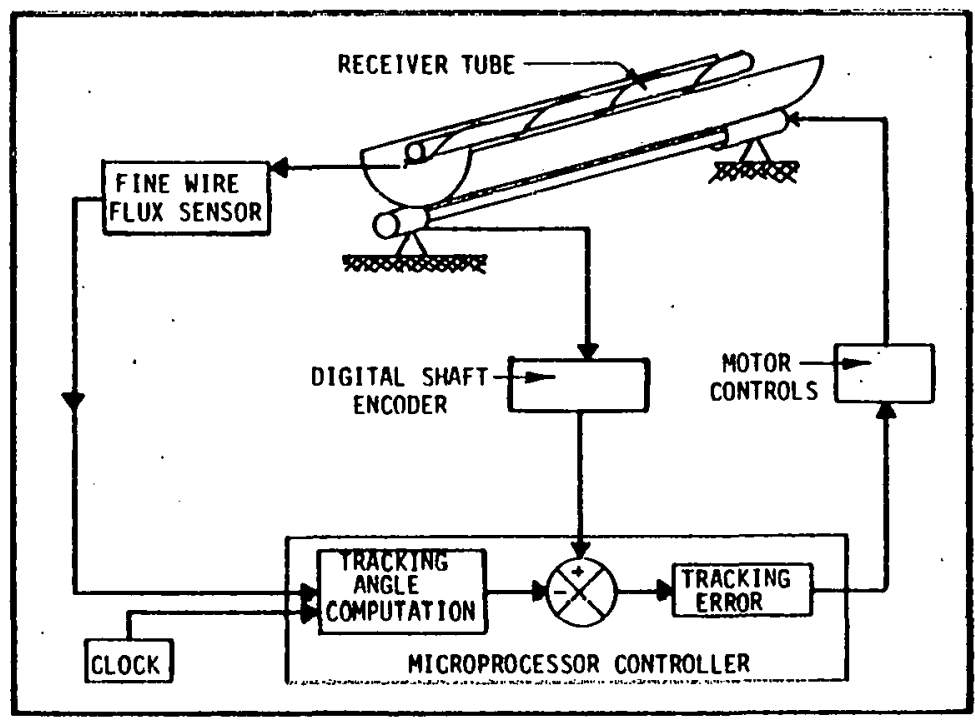

Combined Computer and Aperture Tracking Method Dlagram

Drive mechanisms must provide smooth positioning of the collector assembly yet be strong enough to withstand wind loads and gusts. The two types of drives used are mechanical and electrical. Current drive mechanisms for parabolic troughs use an integral drive pylon with an electrically driven pump interfacing with a hydraulic pressure accumulator and hydraulic actuator to control the collector assembly. This type of drive mechanism provides for emergency defocus which is an important advantage.

\section{Couplings, Pumps, Valves, Blowers, and Dampers}

Especlally in the case of parabolic trough receivers, the coupling between the absorber tube and the supply and return manffolds is frequently done with flex hose. There have been many flex hose fallures in the field due to a combination of carrying high temperature, high pressure flulds together with the torque produced by the movement of the absorber tube relative to the plping mantfold. Flex hose (non-metallic) is durable if temperatures and pressures are below $320^{\circ} \mathrm{F}\left(160^{\circ} \mathrm{C}\right)$ and $150 \mathrm{psia}$, respectively. Metallic hoses are more successful in the field in tolerating higher temperatures and pressures and in avolding leaks. Swivel joint pipes will operate at high temperatures and pressures, but sealing can be a problem. However, present high temperature and high pressure state-ofthe-art flexible connectors are avallable.

Field experience shows that standard pumps used to circulate the heat transfer flulds can cause problems. Frequently, the pumps used are of the centrifugal type with high efficiency. Field problems include air being drawn in through the pump and then circulated on throigh an evacuated tube collector loop, resulting in expansion and fallure of the collector array. Sealing of the pumps can also be a problem. Fail-safe mechanisms must be provided for steam to prevent overpressure during noload conditions. Valves in the system are used to regulate and proportion flow during different modes of operation. Manual and solenoid valves are quite standard, and proper use of these valves (when corrosion as well as 
freezing are avolded) causes few problems. The cost of these valves depends on the rated temperature and pressure.

Blowers and dampers are used in place of pumps and valves in air systems. Dampers, damper actuators, and blowers have operated in general quite satisfactorily, provided they have been sized and installed correctly. Tlght sealing of dampers, however, has been an occasional problem. Backdraft dampers may stick and must be checked routinely on a regular maintenance schedule.

\section{Heat Transfer Fluids and Heat Exchangers}

The heat transfer fluids used in SIPH applications are air, water, water/ ethylene-glycol mixtures, ofls such as Dowtherm J (Dow Chemica1), Therminal 55,60 (Monsanto), and Dow Corning 200 fluids. Alr has the advantage of being non-corrosive, and no freeze protection is required. However, parasitic power requirements for alr systems are usually much higher than for liquid systems. Pressurized water is used in many industrial process heat applications, but water/ethylene-glycol mixtures are used in SIPH systems for freeze protection. The disadvantage of this fluld mixture is that it can form corrosive glycolic acids at stagnation temperatures. Also, ethylene glycol is toxlc and therefore must be protected against leaking into potable water. 0ils used for heat transfer fluids are not corrosive, but they have lower heat capacity and much lower heat transfer coefficients than water. This means that either lower flow rates or larger heat exchangers must be used to achieve the same heat transfer as with water.

The two types of heat exchangers used are liquid-to-1iquid and liquid-toair. Liquid-to-1lquid heat exchangers are generally coiled tubing or shell-and-tube designs. Liquid-to-air heat exchangers are of the fin on tube type, genera1ly made out of copper, aluminum or sometimes galvanized iron. These are fairly standard items except where interfacing with existing hardware requires a spectal design.

\section{Storage}

Heat can be stored in water, rocks, phase change materials and chemicals. Current SIPH systems use elther water or rocks. Water storage systems use commercially avallable tanks of steel, aluminum or plastic. Metal tanks must be protected against corrosion by galvanizing, plastic paints or sheet polymer liners. The cost of metal storage tanks is still high, but they are durable, and a lifetime of 20 years can be expected. Insulating these tanks properly 18 essential and can be quite expensive, espectally in high-temperature systems.

Rock storage has the advantages of being low cost and without corrosion problems, but it requires large volumes and can only operate at relatively low temperatures. Parasitic power requirements can be high for large rockbed storage systems. "Phase change or chemical storage systems have not been presently used in industrial process heat plants. Many phase change materials are candidates for use as storage at low temperatures (below $200^{\circ} \mathrm{F}$ ). For higher temperatures such as those frequently encountered In SIPI applications, phase change materials have received much less 
attention. Problem areas for phase change materials include low heat conductivity, high cost for the phase change materlal and the container, and durability as well, as rellability. Chemlcal storage in the form of heat of reaction is quite expensive and is not being considered except for very high temperature applications, 1.e. in connection with parabolic dish distributed receiver systems. Solchem is one research project in this area (Ref. 29).

\section{B. SIPH Profect Experience}

This section describes the results of site visits to thirteen SIPH plants (two of them only briefly) and interviews with the users. One of these plants is privately financed and owned. It utilizes a SIPH system in confunction with a heat pump (General Extrusions, Inc. In Youngstown, Ohio). The collectors were manufactured by General Extrusions; however, there are no plans to manufacture more collectors for the SIPH market by the company. They are presently planning to market solar air collectors. A request to visit a second privately-owned SIPH plant was not granted because the system has not been operational for some time due to storage failure (Anheuser-Busch, Jacksonville, Florida). The interview with the user was conducted by telephone in this case. Data about these SIPH field applications is summarized in Table.1. of the Executive Summary. Detalled review discussions were also conducted with most of the people involved in SIPH at SERI in Golden, Colorado, and with people working in industrial energy conservation at the Oak Ridge National Laboratory in Tennessee. Additionally, information about a smaller system (J.A. LaCour Kiln Service, Canton, Mississippi) is also included here, although time limitations did not allow a site visit.

\section{Discussion of Problems}

The findings of the site visits are most discouraging. Simflar findings have also been noted in recent SERI publications (Refs. 30,31). The results of the project surveys of the SIPH demonstration sites are individually tabulated later in this section and also contain data taken from the SERI publications supplemented with information obtained through follow-up interviews. A general discussion of problems encountered in the demonstration projects follows below.

\section{a. System Design:}

Poor system design has led to very low overall system efficiencies (actual useful energy obtained) for several plants. Solar heat supplied to one part of a plant could not be rerouted when this part was down for maintenance. At another site, the process is used only a few months of the year, and thuo consumption of the solar energy generated by the SIPI system is not optimized. Also, it was found that cost-effective methods of energy conservation were not applied prior to the SIPH retrofit and that the SIPH system was inappropriately applied (not we11-matched) to end use:

\section{b. Hardware:}

Thermal shock of evacuated tubes resulted in fallures that are still quite common. Seal leaks in pumps (whtch are off-the-shelf 1 tems), improper pump selection, leaks around flare fittings, wetting of insulation, etc. are problems that the users must cope with but which should not occur with 
careful design, good quality hardware, and quality installation. Deterioration of reflective surfaces were notfced in some locations. This could be due to the dirty industrial atmosphere under which these systems must operate. Also selective absorber coatings were peeling in two locations.

Only one of the four flat plate collector facilitles had few operational and maintenance problems (Gold Kist, Inc., Decatur, Alabama). The sitebullt air collectors at Lamanuzzi and Pantaleo Foods in Fresno, California, had problems with deterioration of the glazing. Glazing deterioration also occurred with the liquid collectors at the Red Star laundry in Fresno. Both of these systems used plastic covers. Lamanuzz1 and Pantaleo Foods are now experimenting with other types of glazing. The flat plate liquid collectors at the Campbell Soup Company in Sacramento, California, are deteriorating (leaking) due to a chemlcal reaction which is dissolving the absorber plate. Replacements for these collectors are being discussed. Considering that flat plate collector technology is relatively mature when compared with the more advanced collectors (i.e. evacuated tubes), these experiences exemplify the general state that the SIPH program has achieved. Except for durability and reliability, the operation and maintenance of flat plate collectors posed few problems compared with other advanced-type collectors. The two air systems operated well with good efficiency; the major problem with these alr systems is the relatively large parasitic power loss.

\section{c. Operation and Maintenance:}

Operation and maintenance is a major problem. Three facilities are presently not operating because the owners feel that the $0 \& M$ costs are far in excess of the value of the energy that they recelve from the SIPH system. Additional government funding is sought for two of these facilities. Industrial pollution was so severe in one case that weekly cleaning of the collectors would be required to obtain reasonable operating efficiencles. A related problem is the difficulty of finding experienced maintenance personnel for these systems.

\section{d. Owner Att1tudes:}

In several instances, the energy supplied by the SIPH system is less than one percent of the total industrial process heat used at that plant, and thus the user feels that SIPH is not a significant factor in the operation of the plant. In the case where a larger fraction of the energy is supplied by the SIPH system (perhaps as much as one third), the user is more enthusiastic and is more eager to operate the plant. Several facilities slated for operation at the end of 1979 are still not operational as of January 1981; one facility was operational for checkout but was then shut down because of a multitude of problems. The future of this facility is not known. The user is extremely disappointed in the government's handling of the project, in the equipment supplier, in the designer, and in SIPH in general. These demonstration projects, although almost entirely funded by the government, surely have not Improved the attitudes or confidence of the users toward solar energy. If anything, in a number of applications, the operating experience obtained by the user hurt the lmage of solar energy as a viable energy resource; because of the many defects, the user who is accustomed to dealing with industrial quality equipment has galned a very negative view of solar energy and solar equipment. 
He finds that these systems are unrellable and "on1y a government experiment", besides being outrageously expensive.

None of the users interviewed have any plans for expansion of their SIPH facilities in the near term, if this requires investment of corporate funds. They will, however, serlously conslder purchasing solar energy from a third party. The general attitude is that SIPH is a government experiment used to demonstrate solar energy to the public; the application does not warrant their serious attention to the point of investing their own funds. Also, the users feel that they do not want to enter the energy production business. Some users seem to have joined the program for its public relations value. In view of these attitudes, it is not surprising to find that several users are not operating the SIPH system in the optimum mode. When asked about a contingency plan in the event of gas or ofl rationing or cutoff, the responses varled greatly. None Included solar as an option. However, those that have a contingency plan said they would consider the following: (1) use of lower grade fuels, 1.e. \$6 oil, coal, etc., (2) more energy conservation through energy management and new equipment, (3) a switch to municipal waste or biomass as fuel, or (4) curtailment of activities, even to the point of complete shutdown.

\section{e. Data Collection:}

Despite several milifion dollars spent on data acquisition, very little reliable data is available because of data acquisition system failures. It would have been much more cost-effective to properly measure a few selected sites than to try and obtain detalled data for all SIPH sites. Since many problems occurred with data loggers, on-site observation and data reduction may have given better results.

\section{Specific Operational Results}

Table 9 below 11sts the fifteen SIPH demonstration sites for which detalled information is given in Tables 10 through 24. Perhaps the most disappointing aspect of the site visits was to note the many low-quality

TABLE 9

SIPH Demonstration Sites

COMPANY AND LOCATION

Campbe11 Soup Company, Sacramento, California

TABLE

Riegel Textile Corporation, LaFrance, South Carolina

York Building Products Company, Inc., Harrisburg, Pennsylvania

Gilroy Foods, Inc., Gilroy, California

frold Kist, Inc. Decatur, Mlabama

Lamanuzz 1 and Pantaleo Foods, Fresno, California 15

West Polnt Pepperell, Fairfax, Alabama

Troplcana Products, Inc., Bradenton, Florida

Johnson and Johnson, Sherman, Texas

Home Laundry Company, Pasadena, Callfornia

Dow Chemical, Dalton, Georgla

Red Star Industrlal Service, Fresno, California

General Extrusions, Inc., Youngstown, Ohfo

Anheuser-Busch, Jacksonville, Florida

J.A. LaCour Kiln Service, Canton, Mississippi 
TABLE 10

SIPH System Design Specifications

Campbell Soup Company, Sacramento, California

Application: Hot water for can washing ( 2 alternate lines out of 20). Solar System: $2880 \mathrm{ft}^{2}\left(268 \mathrm{~m}^{2}\right)$ Solargenics single-glazed liquid flat plate collectors at $25^{\circ}$ tilt and $4455 \mathrm{ft}^{2}\left(414 \mathrm{~m}^{2}\right)$ Acurex 3001 parabolic troughs; roof-mounted; $17,000 \mathrm{gal}$. (65,000 liter) storage tank.

Fluid \& Flow Rate: Pressurized water, $20 \mathrm{gpm}$ through collector field, $12.5 \mathrm{gpm}$ to can lines.

Performance Data: Collector outlet temperature $=180-195^{\circ} \mathrm{F}, 60$ psia; designed annual output $=2160 \mathrm{MBtu} /$ year; actual annual energy delivered: N/A; system efficiency: N/A.

Costs: Design $=\$ 204,000$, construction $=\$ 581,000$, data $=\$ 550,000$.

Fue1 Displaced: 非 fue1 o11, G-52 natura1 gas. Operationa1: Nov. 1977.

SIPH System Operation: Hot water from collectors flows to storage tank (no recirculation). From tank, water is pumped through a steam heat exchanger to reach required temperature, then routed to one of two can washing lines. The flat plate collectors are used as preheaters for the concentrating collectors.

Status \& Remarks: Acurex is operating the system. Campbell Soup is the owner but does not want $0 \& \mathrm{M}$ responsibility. Problems: wind damage in Feb. 1978; boost pump and flow regulator had to be retrofitted; digital flow control valve malfunctioned; data logger malfunctioned; controls too complicated. Process load is not matched to solar supply (due to inaccurate design data); solar cannot be used efficiently because wash lines are shut down frequently. Flat plate collectors need replacement due to leakage caused by chemical reaction which deteriorated the aluminum plates. Glass tubes around the absorber pipe of the Acurex collectors broke, most likely due to lack of clearance for thermal expansion.

References: Pp. 24-25 [35], pp. 23-37 [32], pp. 15-23 [33], pp. 187-191 [21], pp. 157-162 [36].

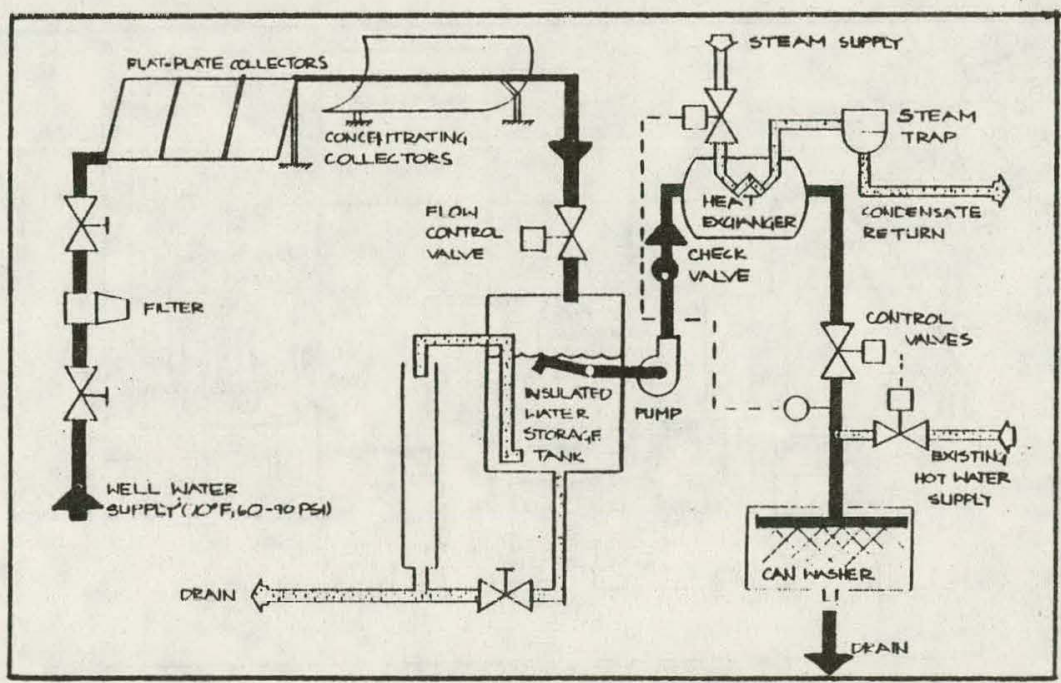

Solar Process Hot Water System at Campbell Soup Company 
TABLE 11

SIPH System Design Specifications

Riegel Textile Corporation, LaFrance, South Carolina

Application: Hot water for textlle dyeing ( 1 of 111100 gal. dye becks). Solar System: $6680 \mathrm{ft}^{2}\left(620 \mathrm{~m}^{2}\right)$ ground-mounted G.E. TC-100 evacuated tubes (396 tubes) at $30^{\circ}$ tilt; 8000 gal. storage tank.

Fluid \& Flow Rate: $30 \%$ ethylene glycol/water in collector 1oop, water in secondary loop, $80 \mathrm{gpm}$.

Performance Data: Collector outlet temperature $=250^{\circ} \mathrm{F}$; temperature at dye beck $=190^{\circ} \mathrm{F}$; designed annual output $=1400 \mathrm{MBtu} /$ year; actual annual energy delivered $=370 \mathrm{MBtu} /$ year (before correction of low flow rate); system efficiency $=8 \%$.

Costs: Design $=\$ 260,000 ;$ construction $=\$ 610,000 ;$ data $=\$ 150,000$. Fue1 Displaced: 非 fuel oil, natural gas. Operational: June 1978.

SIPH System Operation: Ethylene glycol/water solution fransfers heat from collector field to heat exchanger ( $\mathrm{HX}-1$ ) which supplies heat to storage tank. Fluid from tank flows through heat exchanger (HX-2) which supplies heat to dye beck. Heat exchanger $(\mathrm{HX}-3)$ is used for heat recovery.

Status \& Remarks: Early operational problems were leaks around pump and fittings, wetting of insulation, replacement of repeatedly rupturing disks with safety valves, low flow rates, evacuated tube breakage due to stagnation after drainage and thermal shock, and reduction of reflectivity due to plant stack effluent. I observed noticeable degradation of collectors, with approx. $5 \%$ broken. The system has been down for some time because plant is converting from batch dyeing to a new, continuous process. A large structure shades part of the field during winter days. User appeared satisfied with the SIPH system but not with maintenance and repair services of the supplier. User is unsure about future operation of system. There were also problems with data acquisition.

References: Pp. 29-31 [35], pp. 57-81 [32], pp. 25-31 [33], pp. 199-20/1 [21], and Ref. 30.

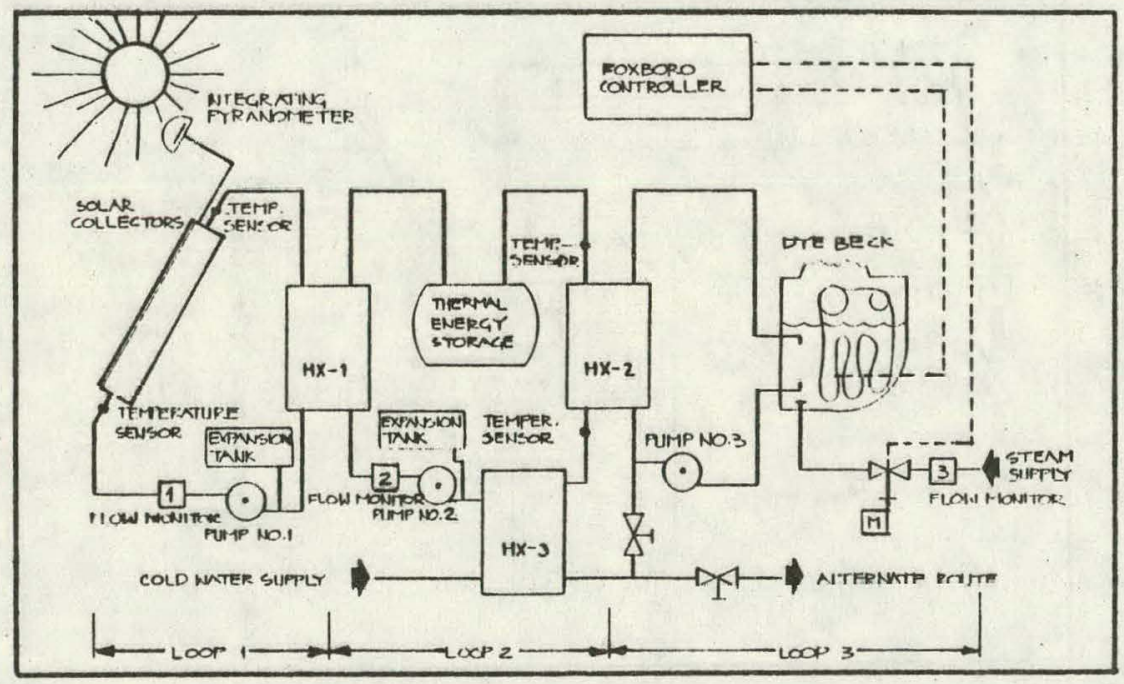

Solar Process Hot Water System at Rlegel Text1le Corporation 
TABLE 12

SIPH System Design Specifications

York Building Products Company, Inc., Harrisburg, Pennsylvania

Application: Hot water for concrete block curing.

Solar System: $9216 \mathrm{ft}^{2}\left(856 \mathrm{~m}^{2}\right)$ AAI Corp. fixed focus/tracking mirror concentrators $(24 \mathrm{x})$, roof-mounted. Built-in storage $=42,000 \mathrm{gal}$.

Fluid: Ethylene glycol/water.

Performance Data: Collector outlet temperature $=200^{\circ} \mathrm{F}$; kiln operating temperature $=160^{\circ} \mathrm{F}$ (average); designed annual output $=1500 \mathrm{MBtu} /$ year; actual annual energy delivered $=320 \mathrm{MBtu} /$ year; system efficiency $=9 \%$.

Costs: Design $=\$ 114,000$, construction $=\$ 450,000$, data $=100,000$.

Fuel Displaced: 非 fuel oil, gas on contingency. Operational: Sept. 1978

SIPH System Operation: Fluid from the collector loop transfers heat to the boiler fluid through a shell/tube heat exchanger. The boiler fluid heats the rotoclave kiln where heat collected during weekends can also be stored.

Status \& Remarks: Black chrome selective absorber coating suffered early severe degradation (not yet solved satisfactorily). Thermosiphoning damaged the heat exchanger, and mirror breakage occurred. There were also problems with data logger operation. AAI is maintaining the system checking once a week. The system was not operating on day of visit and a number of days earlier (AAI personnel was on vacation). Mirrors appeared quite dusty, are washed once a month. Overall, this system seems to be well installed, well insulated and well matched to end use. The owners are happy with the SIPH plant, but because of high $0 \& \mathrm{M}$ costs, solar is not an acceptable alternative if gas or oil are curtailed. They would instead selectively suspend production.

References: Pp. 26-28 [35], pp. 39-55 [32], pp. 5-14 [33], pp. 193-197 [21], pp. 165-169 [36].

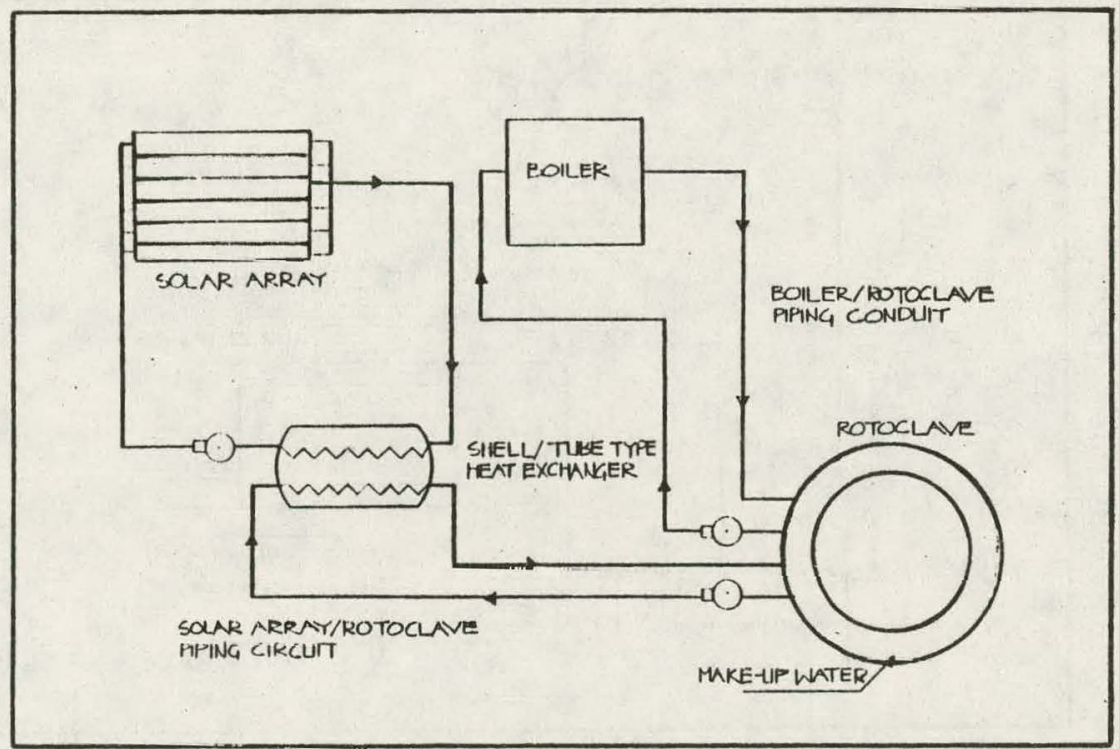

Solar Process Hot Water System at York Bullding Products Company, Inc. 
TABLE 13

SIPH System Design Specifications

Gilroy Foods, Inc., Gilroy, California

Application: Hot air for onion and garlic drying.

Solar System: $5950 \mathrm{ft}^{2}\left(550 \mathrm{~m}^{2}\right)$ G.E. TC-100 evacuated tube collectors, roof-mounted, no storage, $22^{\circ}$ tilt (maximum for summer harvest season). Recirculation from boller condensate tank is used for freeze protection.

Fluid \& Flow Rate: Demineralized water, 0.22 gpm per collector, 88 gpm for system, 65 psig pump discharge.

Performance Data: Collector outlet temperature $=190^{\circ} \mathrm{F}$; designed annual output $=2340 \mathrm{MBtu} /$ year; actual annual energy delivered $=930 \mathrm{MBtu} /$ year; system efficiency $=32 \%$.

Costs: Design $=\$ 226,000$, construction $=618,000$, data $=\$ 178,000$.

Fuel Displaced: Natural gas.

Operational: August 1979.

SIPH System Operation: Hot water from collectors transfers heat to dehydrator by means of a heat exchanger in the incoming air stream. Hot fluid can be routed to boiler condensate tank $1 \mathrm{nnp}$ when drying is not used.

Status \& Remarks: Automatic irrigation-style sprinkling system had to be installed to keep collectors clean. Heat exchanger also needs periodic cleaning. Low-cost wood supporting structure has warped. About $3 \%$ of the tubes have suffered breakage (mostly during instailation). Leaks occurred in the expansion bellows due to improper sizing; design problem resulted in early dumping of heat. The owner is happy with the system after debugging. Comparatively little maintenance is needed. The system did not operate on day of visit (holiday). Some oxidation of tube/fin assembly does not seem to affect performance much.

References: Pp. 47-48 [35], pp. 79-85 [33], pp. 237-243 [21], pp. 171176 [36].

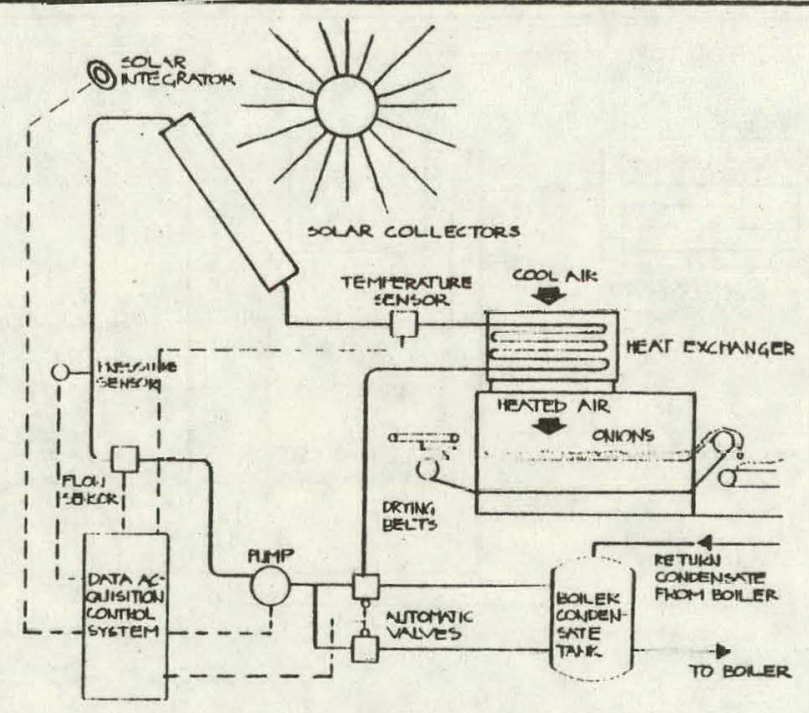

Solar Process Hot Air System at Gilroy Foods, Inc. 
TABLE 14

SIPH System Design Specifications

Gold Kist, Inc., Decatur, Alabama

Application: Preheat direct process hot air for soybean drying.

Solar System: $13,100 \mathrm{ft}^{2}\left(1220 \mathrm{~m}^{2}\right)$ single-glazed flat plate Solaron air collectors; $24^{\circ}$ east of south, $15^{\circ}$ slope, mounted on structure over parking 1ot. No storage.

Fluid \& Flow Rate: Air, 27,000 cfm.

Performance Data: Collector outlet temperature $=150^{\circ} \mathrm{F}$; designed annual output $=3700 \mathrm{MBtu} /$ year; actual annual energy delivered $=744 \mathrm{MBtu} /$ year; system efficiency $=19 \%$.

Costs: Design $=\$ 291,000$, construction $=\$ 823,000$, data $=\$ 186,000$.

Fuel Displaced: 非 fuel oil, natural gas. Operational: July 1978.

SIPH System Operation: Hot air from solar collectors is ducted through $4 \mathrm{ft}$ duct to dryer house where it is entrained with ambient air, then heated with three conventional dryers.

Status \& Remarks: Data logger failed. Wet insulation was noted. Frequent washing of glazing is needed; a high pressure pump/detergent system was installed to remove sticky soybean gum. A filter had to be installed also on nearby bean cleaner to reduce dirt contamination of collectors. The support structure was overdesigned. High parasitic power $(10 \%)$ is used because of long duct run and large volume of air. Although the plant manager is happy with the system, he does not consider solar a viable option. The company is working on contingency plans that include use of municipal waste or biomass. The plant went to a day maintenance/ night drying schedule, thus utilizing the SIPH system only about $50 \%$.

References: Pp. 45-46 [35], pp. 111-120 [32], pp. 63-78 [33], pp. 231235 [21].

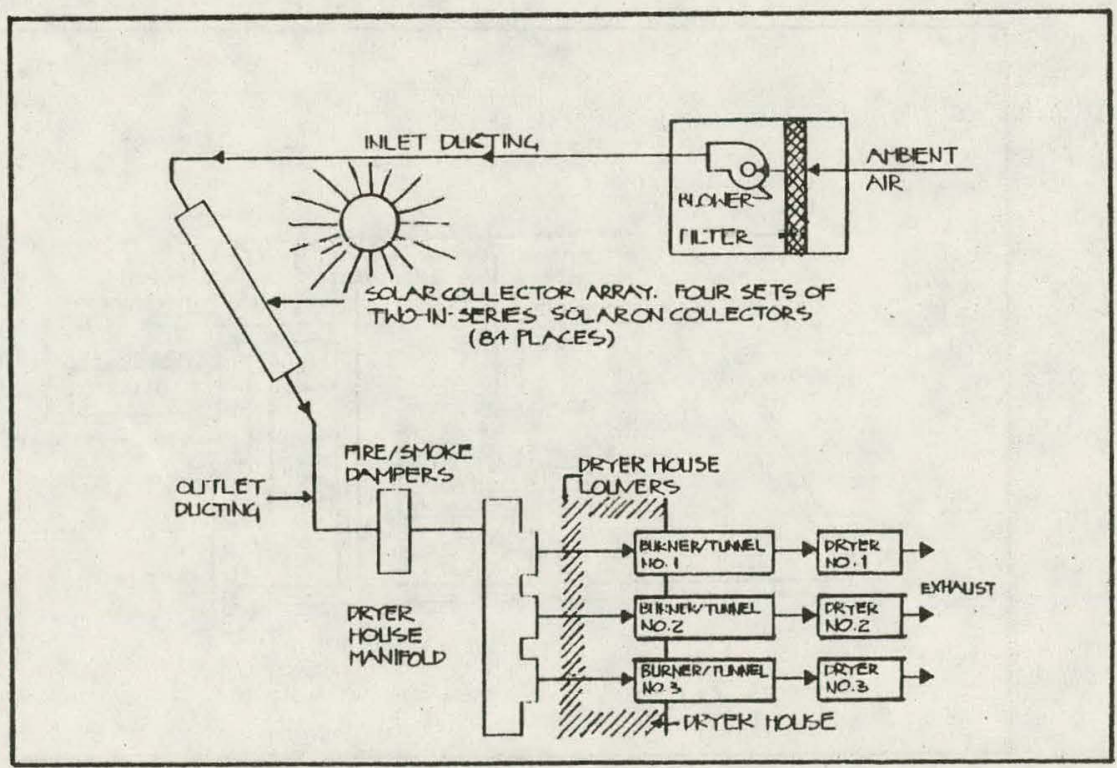

Direct Process Solar Hot Air System at Gold Kist, Inc. 
TABLE 15

SIPH System Design Specifications

Lamanuzzi and Pantaleo Foods, Fresno, California

Application: Direct process hot afr to 1 out of 12 tunnels for raisin and prune drying.

Solar System: $21,000 \mathrm{ft}^{2}\left(1950 \mathrm{~m}^{2}\right)$ site-built single-glazed flat plate air collectors, ground-supported, $36^{\circ} \mathrm{tilt;} 14,000 \mathrm{ft}^{3}\left(330 \mathrm{~m}^{3}\right)$ gravel storage.

Performance Data: Collector outlet temperature $=160^{\circ} \mathrm{F}$; designed annual output $=2300 \mathrm{MBtu} /$ year; actual annual energy delivered $=1260 \mathrm{MBtu}(1978)$ and $647 \mathrm{MBtu}$ (1979); system efficiency $=18 \%$.

Costs: Design $=\$ 261,000$, construction $=\$ 545,000$, data $=\$ 154,000$.

Fuel Displaced: Natural gas.

Operational: July 1978.

SIPH System Operation: Hot air from collectors is ducted directly to the drying tunnel or to the rockbed. A heat recovery wheel recovers about $80 \%$ of exhaust heat from the tunnel and furnishes input air to solar collectors.

Status \& Remarks: A small sprinkler is used for cleanlng. Thiere wese problems with the controller and plastic glazing deterioration (the Lexan glazing cracked). Different types of glazing are now being tested. There are some concerns with vandalism. The system works well with good end use match when it is operating (use is only seasonal). The heat recovery wheel recovers twice the amount of energy supplied by solar at $1 / 10$ th the cost of the SIPH system. The user is satisfied with the SIPH system. Use of student labor ( $\mathrm{Ca} 1 \mathrm{Poly}$ ) significantly reduced system cost. Parasitic energy consumption is about $11 \%$ of collected solar energy.

References: Pp. 40-44 [35], pp. 83-97 [32], pp. 39-49 [33], pp. 205-213 [21], pp. 271-277 [36].

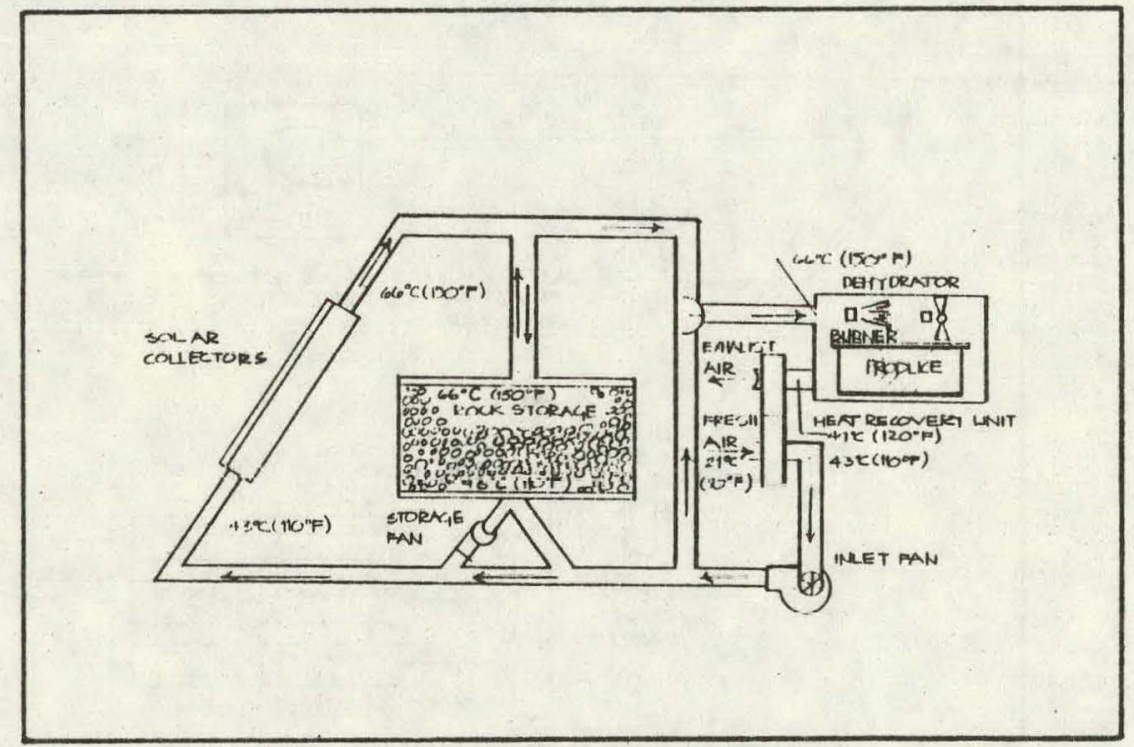

Direct Process Solar Hot Air System at Lamanuzi and Pantaleo Foods 
TABLE 16

SIPH System Design Specifications

West Point Peppere11, Fairfax, Alabama

Application: Process steam for fabric drying.

Solar System: $7500 \mathrm{ft}^{2}\left(700 \mathrm{~m}^{2}\right)$ Honeywell half-parabolic trough collectors with tracking axis mounted $40^{\circ} \mathrm{SE}$ to $\mathrm{NW}$, continuous tracking; no storage. Collectors are roof-mounted.

Fluid \& Flow Rate: Pressurized water, $48 \mathrm{gpm}$ (system).

Performance Data: Collector outlet temperature $=380^{\circ} \mathrm{F}$ @ $275 \mathrm{psig}$; output steam $100 \mathrm{p}$ temperature $=320^{\circ} \mathrm{F}$ @ $70 \mathrm{psig}$; designed annual output $=$ $1220 \mathrm{MBtu} /$ year; no useful energy delivered since startup; system efficiency: N/A.

Costs: Design $=\$ 146,000$, construction $=\$ 598,000$, data $=\$ 150,000$.

Fuel Displaced: Coal.

Operational: Dec. 1978.

SIPH System Operation: Pressurized water is circulated through collector field and through heat exchanger in the steam generator which is normally at $370^{\circ} \mathrm{F}$. Steam flows from the generator into the steam line at $320^{\circ} \mathrm{F}$ to the dryers.

Status \& Remarks: There were problems with the shadow bar tracker, gear box and field circulation pump failures, leaks due to freeze-up and rotary joint leaks, and reflector delamination. Plant manager and engineer do not know what will happen to the SIPH plant. User is very disappointed since practically no energy has been supplied to process steam in almost two years. During my visit I noted rusting components. The engineer was very interested in solar energy (passive residential). The vicepresident of the company has been very much interested in solar for many years. They may give over $O \& M$ to another contractor, if cost is proved to be less than the energy derived from the system. They had difficulty working with DOE.

References: Pp. 245-249 [21], pp. 133-140 [33], pp. 171-178 [32], pp. 49-50 [35].

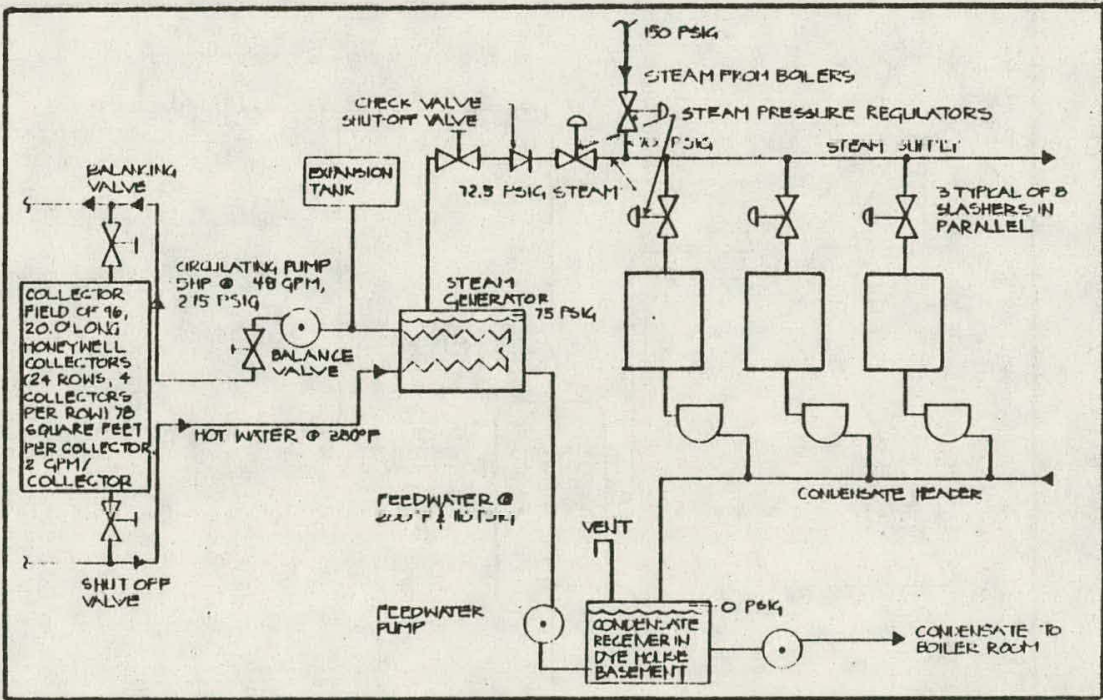

Solar Process Steam System at West Point Pepperell 
TABLE 17

SIPH System Design Specifications

Tropicana Products, Inc., Bradenton, Florida

Application: Low pressure process steam for water heating (juice defrosting), cold storage dehumidification, and fruit juice pasteurizing, etc.

Solar System: $10,000 \mathrm{ft}^{2}\left(930 \mathrm{~m}^{2}\right)$ G.E. TC-300 evacuated tubes with reflectors (3x); ground-mounted, no storage.

Fluid \& Flow Rate: Pressurized water, $0.3 \mathrm{gpm}$ per collector.

Performance Data: Collector output temperature $=300-400^{\circ} \mathrm{F}, 20-150$ psia;

designed annual output $=2700 \mathrm{MBtu} /$ year; no energy delivered; system efficiency: N/A.

Costs: Design $=\$ 235,000$, construction $=\$ 1,362,000$, data $=\$ 274,000$

(proposed).

Fuel Displaced: Natural gas and 非 fuel oil. Operational: Proj. 2/81.

SIPH System Operation: Water under pressure is circulated through collectors and through a heat exchanger in unfired boiler steam generator. The steam drawn from the generator to the main steam line is about $260^{\circ} \mathrm{F}$.

Status \& Remarks: Since Feb. 1980, the system has not yet operated, although several checkouts were performed. Problems include: pump failure (modification to manifold header required), leaks, 4000 silver solder joints needed repair, $65 \%$ of glass envelopes replaced in mid 80 . Structural problems required moving of collector field at higher cost, lower efficiency. User is unsure about future status of SIPH plant. Latest report says that with additional funds, plant should be operational by Feb. 1981. On day of visit, $5 \%$ of tubes appeared damaged (broken or delamination). User appears to be very well informed about solar energy utilization but does not consider SIPH viable because $0 \& M$ costs far exceed value of energy delivered. The company is still interested in solar if it can purchase the energy from another operator.

References: Pp. 151-160 [36], pp. 263-265 [21], and Ref. 37.

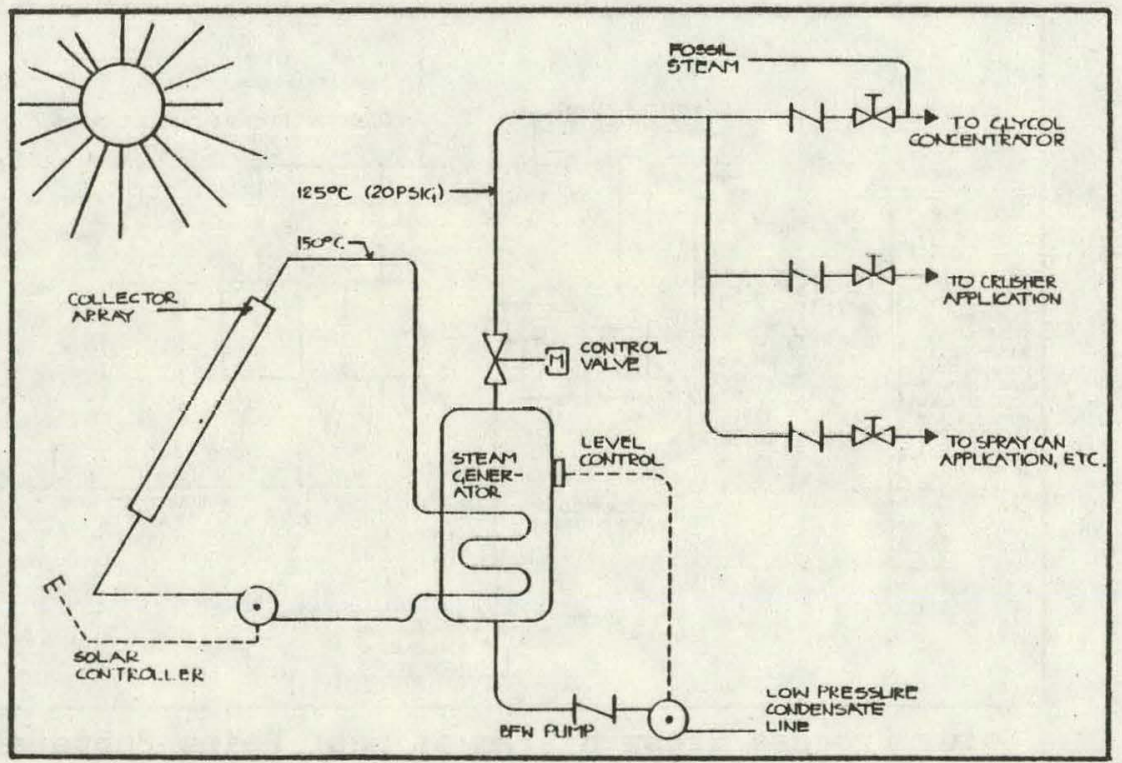

Solar Process Steam System at Tropicana Products, Inc. 
TABLE 18

SIPH System Design Specifications

Johnson and Johnson, Sherman, Texas

Application: Process steam for gauze bleaching, redesigned for supply to plant steam main.

Solar System: $11,520 \mathrm{ft}^{2}\left(1070 \mathrm{~m}^{2}\right)$ Acurex 3001 parabolic troughs, groundmounted, no storage. Tracking axis $45^{\circ}$ from $\mathrm{N}-\mathrm{S}$.

Fluid \& Flow Rate: Pressurized water, $60 \mathrm{gpm}$.

Performance Data: Collector output temperature $=350^{\circ} \mathrm{F}, 125$ psia; designed annual output $=1400 \mathrm{MBtu} /$ year; actual annual energy delivered $=$ $1000 \mathrm{MBtu} /$ year (estimate, based on 7 months operation); system efficiency: N/A.

Costs: Design $=214,000$, construction $=\$ 1,613,000$, data $=\$ 200,000$. Fuel Displaced: 011.

Operational: Jan. 1980.

SIPH System Operation: Pressurized heated water from the collector field is circulated to flash boiler where the $350^{\circ} \mathrm{F}$ water flashes to steam and is added to the plant steam main at $340^{\circ} \mathrm{F}$ through a pressure regulating valve. The $5000 \mathrm{gal}$. flash boiler reservoir retains thermal energy to provide freeze protection to the collectors when needed.

Status \& Remarks: The SIPH system is well designed and operating well, although at very high system cost (about $\$ 1000 / \mathrm{MBtu}-y e a r$ ). However, because of the satisfactory performance experience, the user is enthusiastic about the system and may eventually use corporate funds for future expansion. There were only some minor problems in instrumentation, and gear drive had to be changed. Johnson and Johnson selected the manufacturer and contacted $\mathrm{DOE}$ and insisted on being an active participant in the design (with improved efficiency). Aesthetics was an important design consideration.

References: Pp. 161-173 [33], pp. 43, 251-256, 472 [21].

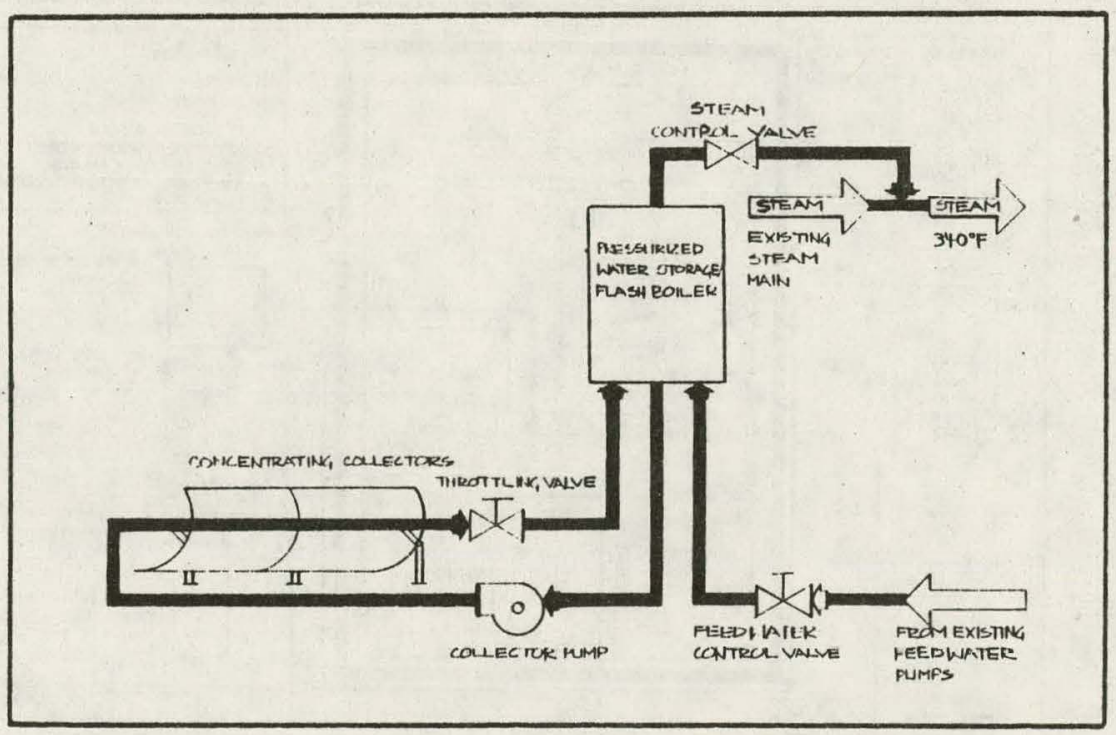

Solar Process Steam System at Johnson and Johnson 
TABLE 19

SIPH System Design Specifications

Home Laundry Company, Pasadena, California

Application: $25 \%$ of steam and some hot water for commercial laundering and dry cleaning.

Solar System: $6500 \mathrm{ft}^{2}\left(600 \mathrm{~m}^{2}\right)$ Dell parabolic troughs, continuous tracking, $\mathrm{N}-\mathrm{S}$ mounted on support platform.

Fluid \& Flow Rate: Pressurized water, 110 psig steam, recirculation from small buffer storage tank for freeze protection.

Performance Data: Collector output temperature $=350^{\circ} \mathrm{F} @ 125$ psia; designed annual output $=1600 \mathrm{MBtu} /$ year; actual annual energy delivered: N/A; system efficiency: N/A.

Costs: Design $=\$ 167,000$, construction $=\$ 801,000$, data $=\$ 55,000($ extension is being negotiated for Phase III).

Fuel Displaced: Natural gas.

Operationa1: Apri1 1981 (cst.)

SIPH System Operation: Pressurized water circulates through collectors to buffer storage tank or to heat exchanger in steam generator which is at $340-390^{\circ} \mathrm{F}$. Steam is supplied to main plant steam line at $340^{\circ} \mathrm{F}$.

Status \& Remarks: Startup and checkout were not yet completed on date of visit, although system was to be operational by Feb. 1980. Delays were due to technical problems and to workers' strike, EPA requirements, tax problems. Collector drive motors failed due to faulty switching and high torque. Circulating pump falled; malfunction in gate valve led to receiver tube breakage. Oscillations are experienced in receiver tubes. During one checkout, $20 \%$ of tubes broke due to stagnation. Expensive support structure was required since no roof or ground space was available. The management has implemented energy conservation measures in plant operation. "Fast track" approach to construction was not successful in avoiding delays. References: Pp. 141-150 [33], pp. 257-261 [21], pp. 285-288 [36].

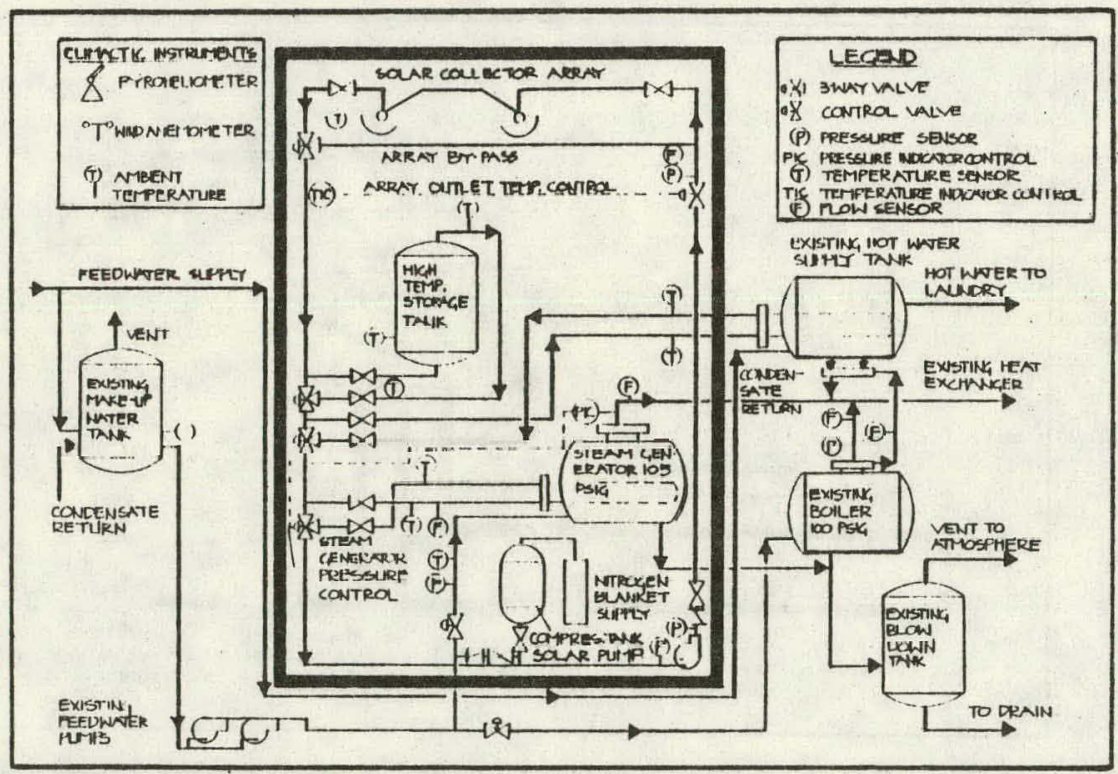

Solar Process Steam System at Home Laundry Company 
TABLE 20

SIPH System Design Spacifications

Dow Chemical, Dalton, Georgia

Application: Process steam for latex production.

Solar System: $9930 \mathrm{ft}^{2}\left(920 \mathrm{~m}^{2}\right)$ Suntech-Hexcel parabolic troughs, sunhour tracking, $\mathrm{N}-\mathrm{S}$ orlentation with $10^{\circ}$ tilt; no storage.

Fluid \& Flow Rate: Dowtherm-LF organic fluid.

Performance Data: Collector output temperature $=350^{\circ} \mathrm{F}$ at 150 psig; designed annual output $=2540 \mathrm{MBtu} /$ year; actual annual energy delivered: N/A; system efficiency: N/A.

Costs: Design $=\$ 195,000$, construction $=\$ 870,000$, data $=\mathrm{N} / \mathrm{A}$.

Fuel Displaced: 75\% interruptible natura1 gas, $25 \%$ 非 fuel oil (非 6 oil contingency).

Operational: December 1980.

SIPH System Operation: The heat transfer fluid circulates through the collectors and then boils water in a kettle boiler to produce steam. An accumulator tank connected to the fluid loop serves as expansion and dump tank.

Status \& Remarks: Checkout had been completed by date of visit. There has been very little operational experience as yet and insufficient data to evaluate performance. No major problems have been reported so far.

References: Pp. 273-275 [21], pp. 201-204 [36].

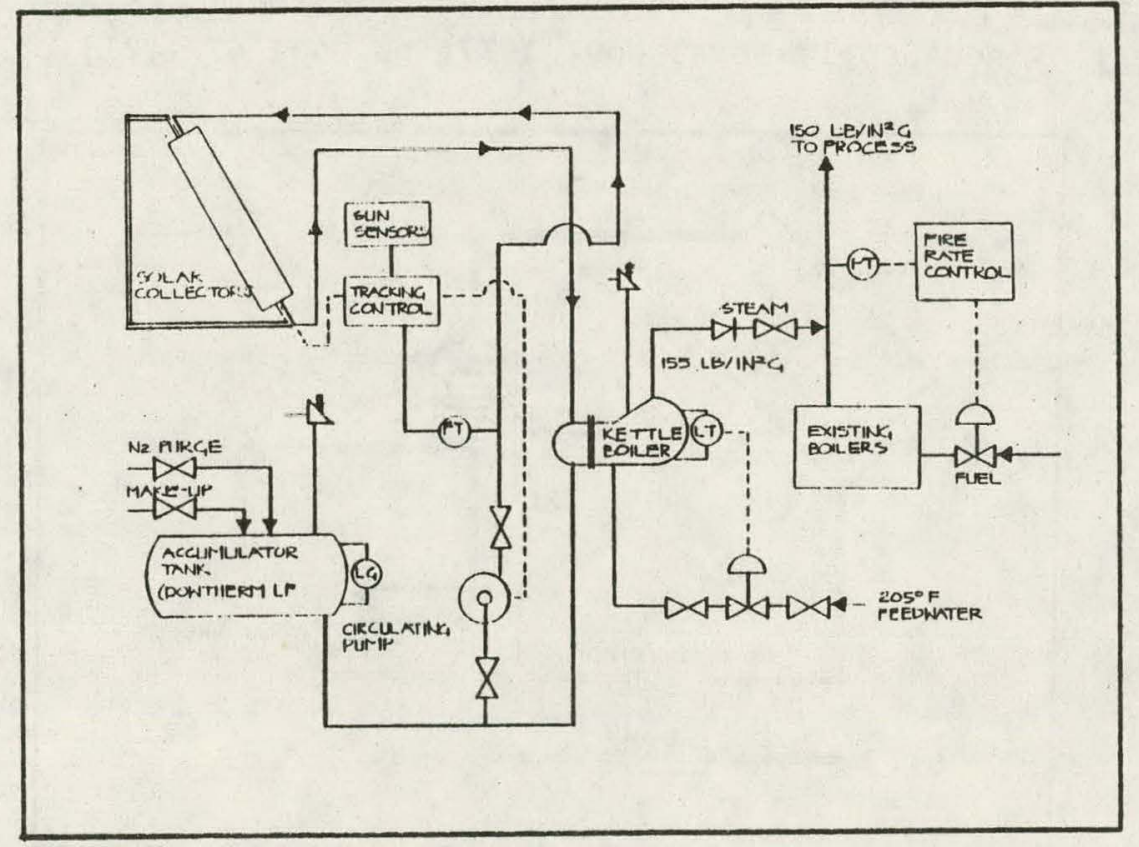

Solar Process Steam System at Dow Chemical 
TABLE 21

SIPH System Design Specifications

Red Star Industrial Service, Fresno, California

Application: Water preheating for industrial laundering.

Solar System: $6500 \mathrm{ft}^{2}\left(600 \mathrm{~m}^{2}\right)$ Ing Manufacturing liquid flat plate collectors, roof-mounted; 12,000 gal. storage.

Fluid: Water (drain-down).

Performance Data: Collector output temperature $=135^{\circ} \mathrm{F}$; designed annual output, actual annual energy delivered, and system efficiency: N/A.

Costs: Total $=\$ 233,000$ (25\% privately funded).

Fuel Displaced: Natural gas.

Operational: Summer 1977.

SIPH System Operation: Incoming city water passes through waste water heat reclaimer, then through solar collectors and through the steam heat exchanger which raises water temperature to $180^{\circ} \mathrm{F}$ before it enters the wash wheels.

Status \& Remarks: The SIPH system had problems with peeling paint and leaks. The original plastic was replaced with mylar collector glazing which is now deteriorating (creeping); replacement is being negotiated. In general, user is satisfied with the system. The company brochure indicates that $15-20 \%$ of system energy is derived from solar, $30-40 \%$ from waste recovery, and the remainder from the boiler steam generator. Economically, returns from heat recovery are much greater. Solar is saving $\$ 4,000 /$ year, heat recovery $\$ 12,000 /$ year on a $\$ 30,000$ investment. The user feels that reduced system efficiency is due to the deterioration of the collector surfaces and could have been avoided if design and system had been more thoroughly tested before installation. There is in general little interest in the SIPH system at the plant.

References: Linen Supply News, Nov. 1977; pp. 471-477 [21].

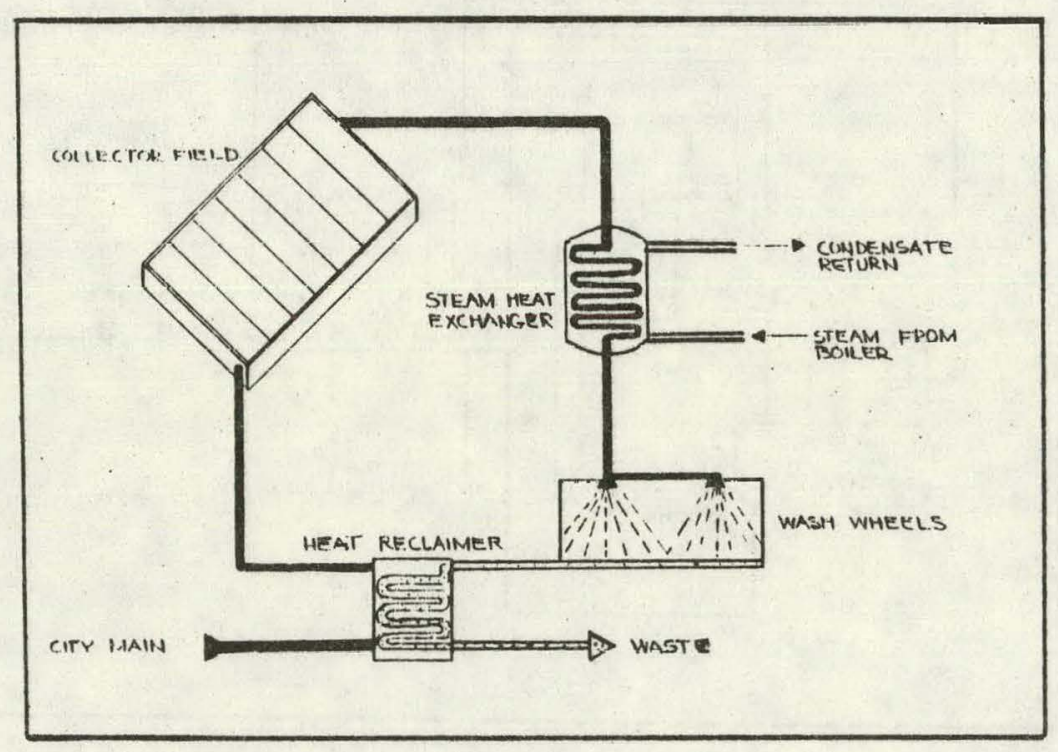

Solar Water Preheating System at Red Star Industrial Service 
TABLE 22

SIPH System Design Specifications

General Extrusions, Inc., Youngstown, Ohio

Application: Heating of alkaline-cleaning tank (extrusion of aluminum parts).

Solar System: $4400 \mathrm{ft}^{2}\left(410 \mathrm{~m}^{2}\right)$ General Extrusions Model LTC-367 concentrators with manual controls; seasonal tracking with manual adjustment. Light-weight array is bolted directly to steel roof. 3600 gal. storage.

Fluid \& Flow Rate: $400 \mathrm{gal}$. light oil, $80 \mathrm{gpm}$ max.

Performance Data: Collector output temperature $=190^{\circ} \mathrm{F}$. Privatelyfunded SIPH system - no hard data available. Only project using solarassisted heat pump system.

Costs: $\$ 150,000$ (est.). Design approx. $20 \%$ state-funded. Recently $\$ 50,000$ funded for monitoring.

Operationa1: Sept. 1977.

SIPH System Operation: Refer to mode diagrams below for system operation. Heat storage is in rinse tank.

Status \& Remarks: The SIPH system is working fine after three years of operation. Apparently, no problems arose with galvanic action, although absorber is aluminum with iron piping. No performance data is available. Operation requires collector array adjustment 8 times a year. Westinghouse Templifier heat pump operation was also troublefree.. Some early outgassing has been corrected. Collectors require occasional cleaning. System was not operating on date of visit due to snow storm.

References: Pp. 343-347 [21].

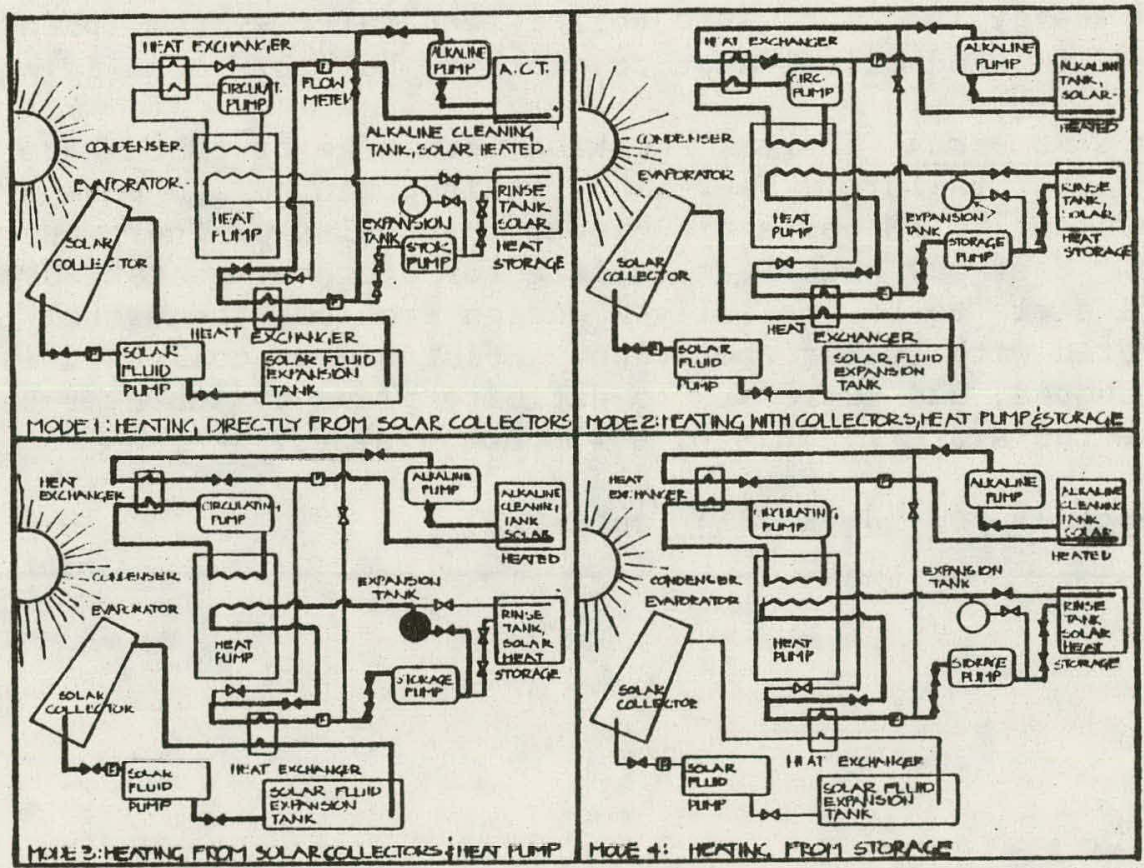

Solar Process Hot Water System at General Extrusions, Inc. 
TABLE 23

SIPH System Design Specifications

Anheuser-Busch, Jacksonville, F1orida

Application: Designed to supply $1 / 3$ of energy for 1 of 7 pasteurizers.

Solar System: $4600 \mathrm{ft}^{2}\left(470 \mathrm{~m}^{2}\right)$ Owens-Illinols "Sunpak" evacuated tube collectors; storage not working.

Fluid: Softened boller feed water.

Performance Data: Collector output temperature $=165^{\circ} \mathrm{F}$; designed annual output, actual annual energy delivered, and system efficiency data not available.

Costs: N/A (100\% privately funded).

Fuel Displaced: Natural gas and oil.

Date Operationa1: April 1978.

SIPH System Operation: Water heated in the collectors is circulated through a heat exchanger which heats water in a pasteurizer to $145^{\circ} \mathrm{F}$. Excess energy is dumped into boller feed water system (preheated). It was designed to send excess heat to storage, but this mode is not working.

Status \& Remarks: Thermal shock and breakage of tubes have occurred due to capacitor failure. User is very disappointed and unhappy with the SIPH system. $0 \& M$ costs are higher than value of energy derived from system. User may want to negotiate for operator to take over the system. Failure seems to be basically a design problem; the system is not well integrated with boller operation. Solar energy collected is presently being dumped, and there are no definite plans by Anheuser-Busch to operate the system. This site was not visited.

References: Pp. 58-59 [21] (outdated). 
TABLE 24

SIPH System Design Specifications

J.A. LaCour Kiln Service, Canton, Mississippi

Application: Hot air for hardwood lumber kiln drying (designed to supply $40 \%$ of heat of one 50,000 board ft kiln or $20 \%$ of two kilns).

Solar System: $2520 \mathrm{ft}^{2}\left(280 \mathrm{~m}^{2}\right)$ Chamberlain liquid double-glazed flat plate collectors with $30^{\circ}$ tilt and $2400 \mathrm{ft}^{2}$ anodized aluminum reflectors at $40^{\circ}$ tilt, in a sawtooth roof-mounted arrangement.

Fluid \& Flow Rate: 5000 gal. water, rust-inhibited, circulates through $650 \mathrm{ft}$ of fin-pipe heat exchanger in kiln.

Performance Data: Collector output temperature $=160^{\circ} \mathrm{F}$; designed annual output $=860 \mathrm{MBtu} /$ year; actual annual energy delivered $=430 \mathrm{MBtu} /$ year (estimated); system efficiency: N/A.

Costs: Design $=\$ 71,000$, construction $=\$ 286,000$, data $=\$ 119,000$.

Fuel Displaced: Direct-fired gas/o11. Operational: June 1978.

SIPH System Operation: Hot water from the collectors is stored in the $5000 \mathrm{gal}$. insulated steel tank. Hot water from storage is then pumped to the kiln liquid-to-air heat exchanger. Existing fans distribute the hot air over the lumber. Normally, the solar heat is directed to the kiln which has the lower temperature requirement, although both kilns may draw solar heat simultaneously.

Status \& Remarks: The SIPH system had problems with data collection; data collection was terminated in May 1979. Overheating of storage tank damaged PVC piping. A pump needed replacement, the reflectors are oxidized to the point where they are almost completely ineffective, and some absorber plate leakage has occurred. The system (although designed for flexible operation) is not used to best advantage by the operator. Because of the small size of the system and time limitations, this site was not visited.

References: Pp. 99-109 [32], pp. 51-61 [33], pp. 215-229 [21].

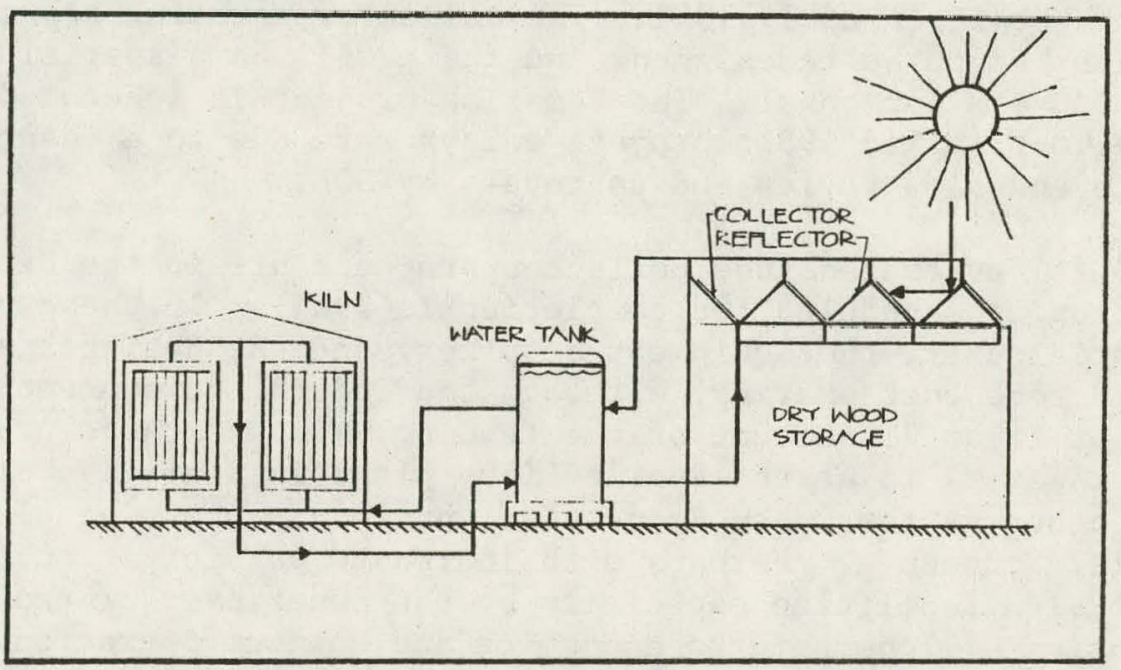

Solar Process Heat (Air) System at J.A. LaCour Kiln Service 
installations. This contrasted very painfully with the optimistic reports published about the SIPH demonstrations by DOE (Refs. 32,33,21) and equipment manufacturers (Ref. 34). System efficiency, as used in Tables 10 through 24, is the total solar energy delivered minus parasitic energy consumed for pumps, fans, controls (including conversion losses), divided by the product of effective collector area and the total daily incident insolation per unit collector area. Annual efficiency would even be lower, since daily efficiency is calculated when the SIPH system. is operating. It is interesting to note that not one of the SIPH installations was operating during the day of visit for a number of reasons: inclement weather, holiday, routine maintenance, hardware breakdown, industrial process not operating, maintenance personnel not avail$a b 1 e$, etc.

In conclusion, only those SIPH installations worked satisfactorily where correct design achieve a good match between solar energy output and industrial process or plant operation and only where this was accompanied by good-quality hardware and workmanship in installation and $0 \& \mathrm{M}$, and where the user was actively involved with the SIPH system. Needless to say, to achieve this type of working system takes much effort and expense. Because of this expense, it is essential that companies considering even a small SIPH project investigate all cost-effective means of energy conservation first and then integrate the solar system into their energy management plan.

\section{Other SIPH Projects}

DOE in the last two years had funded a number of additional projects. Some of these were only for the design phase, some are nearing operation. Among those where construction is almost complete are SIPH systems at the U.S. Steel Chemicals Company plant in Haverhil1, Ohio (process steam), at the Caterpillar Tractor Company in San Leandro, California (process hot water), at the Southern Union Company Famariss Oil Refinery in Hobbs, New Mexico (process steam), at the Ore-Ida Foods plant in Ontario, Oregon (process steam), and at the Lone Star Brewery in San Antonio, Texas (process steam). System tests and evaluation at the Ore-Ida plant are scheduled to begin in early 1981. The collector mounting scheme at this installation had to be redesigned, and there will be a special training program for 0 \& $M$ personnel. The Famariss project is scheduled for SIPH system checkout in mid 1981; project delays were due to a change in collector site and slow review and approvals by DOE.

Two 50,000 $\mathrm{ft}^{2}$ evacuated tube collector projects are in the design phase (construction is scheduled for completion in 1984). In these projects, the industrial user, the equipment supplier, and the designer are participating in some cost sharing, although the federal government is still supplying at least 75 percent of the funding. One of these projects (for process hot water) is at the Nestle-Libby plant in Santa Isabel, Puerto Rico, the other at the Tyson Foods, Inc. poultry processing plant in Shelbyville, Tennessee. Perhaps with increased participation in the funding of SIPH facilities especially by the owner/user of the system, more attention will be paid to economics and optimum operation. 


\section{Economic Assessment}

Industry's bottom 1ine is profits; Industry depends on successful operation at minimum cost. Thus economics will be one of the prime incentives (or barriers) for Industry in selecting alternate energy sources. Another incentive or barrler of course is the avallabllity of conventional fuels. Solar energy suffers two handlcaps in an economlc comparison with fossil fuels :

1. Solar systems are still in the development stage, costs are high, and systems are unrellable. 011 and gas prices on the other hand do not reflect their replacement value. They have been kept low by regulations, subsidies, and market forces.

2. Conventional energy sources are paid for by the industrial user on a pay-as-you-go basis and are deductible operating expenses. Solar costs are up-front. expenditures and are treated as capital investment; thus lack of capital.will have a significant influence also.

In the SIPH demonstration program, a number of factors have affected economics adversely, such as mistakes in design (Improper end-use match), low-quality hardware, expenslve support structures, inapproprlate, inefficient operation, and extensive, frequent maintenance (especially for cleaning). These are in addition to high costs for design, construction, and monitoring. In some of the profects, $0 \& M$ costs have been as high as $\$ 30 / \mathrm{MBtu}$. Future commercial plants are expected to have lower $O \& M$ costs.

Among SIPH system suppliers, there appears to be very little agreement on future collector costs. Pröfections from manufacturers range from a low of $\$ 35 /$ MBtu per year to $\$ 165 / \mathrm{MBtu}$ per year of energy delivered. A recent study shows that the demonstration projects averaged system costs of about $\$ 70 / \mathrm{ft}^{2}$, with a cost breakdown as follows: collectors 40 percent, construction 20 percent, support structure 15 percent, and miscellaneous 25 percent (Ref. 38). Installed system costs have decreased slightly for some systems over the last few years. However, collector cost per unit area has gone up from $\$ 16 / \mathrm{ft}^{2}$ to $\$ 25 / \mathrm{ft} \mathrm{t}^{2}$ for concentrating collectors and from $\$ 12 / \mathrm{ft}^{2}$ to $\$ 22 / \mathrm{ft} \mathrm{t}^{2}$ for flat plate collectors in the last five years (Ref. 39). Because of the materlals and labor involved, projections that assume decreasing prices are simply not realistic, such as the DOE cost goals of $\$ 10 / \mathrm{MBtu}$ by 1985 and $\$ 7 / \mathrm{MBtu}$ by 1990 (MISR program). Site generated SIPH simply cannot compete economically with other alternatives in the near term.

A recent life-cycle cost analysis concluded that a SIPH system built in the U.S. Southwest could not cost more than $\$ 7 / \mathrm{ft}^{2}$ if a satisfactory rate of return for the investment is expected. In the northeastern U.S. the allowable system cost should only be about half this. With government incentives. (20 percent investment tax credit and a 90 percent loan at 6 percent interest), the cost of the solar system in the Southwest could go as high as $\$ 25 / \mathrm{ft}^{2}$ and st111 be economically competitive (Ref. 40). Methods to calculate the economics of a SIPH profect are available in References 41 and 42.

Alternate methods of financing, such as the Solar Management Company/ Limited Partnership plan devised by W.C. Dickinson of Lawrence Livermore National Laboratory where the user supplies the land and the SIPH system owner sells the energy to the user, could improve the market potential 
of SIPH, but these methods must be coupled with more favorable tax laws for Industrial application (Ref. 43). However, these economic incentives w11l be effective only if the technology is sufficlently mature. This type of arrangement would allow the cost of solar energy to be charged to operating expenses rather than being treated as capital investment. Under present tax law, solar energy is effectively "taxed" at up to 46 percent, since the energy savings due to solar are taxed at the same rate as the company's profits (Ref. 44).

At present, only very generous tax rebates (federal and state comblned of over 50 percent of system cost) are able to overcome these economic barriers and then only in certain applications and smaller systems. Solar energy applications do not seem to follow the economy of scale rules of conventional energy plants, thus larger systems will not necessarily have higher economic efficlency (lower cost per unit output). Industry typically demands a rate of return on its investments of 25 to 40 percent (Ref. 21). However, even 80 percent subsidies are not a satisfactory answer, since the problems of high $0 \& \mathrm{M}$ costs or large capital requirements would still remain unsolved. Strong competition for investment capital can be expected from utilities in the near future. It is interesting to note that solar equipment manufacturers/suppliers were asked during the 1979 SIPH conference working group session if they had solar systems actually supplying energy to their process needs. Only two (of 15) replied affirmatively, and one other sald he was considering installation some time in the future (Ref. 21).

Recently; DOE has begun to emphasize the following three objectives for its alternate energy programs:

- Reduction of oll supply vulnerability*

- Economic efficlency (cost/benefit)

- Open options for the future.

Energy conservation would have to be ranked very much ahead of SIPH in all three of these, with fuel substitutions such as biomass next, together with wind and cogeneration, and expensive SIPH last. From experience, it has typlcally been shown that simple low-cost housekeeping procedures can improve energy use by a minimum of 5 to 10 percent in industry. Reduction of heat $10 s s e s$ or use of more efficient equipment or processes can result in 10 to 20 percent energy savings per unit product output. Heat recovery represents a major possibility for energy savings in many installations. Case studies (and experience) have shown that such installations can have payback periods of less than one year at present energy cost (Ref. 41). If the government belleves that its resources should be invested in future energy programs that are highly feasible (economically and technically), short term, have good potentlal for widespread application and for reducing the consumption of ofl and natural gas, then alternatives such as energy conservation, cogeneration, and use of alternate energy sources such as hydros. wind, blomass, municlpal waste, and low-cost solar should recelve support and funding ahead of SIPH development and demonstration.

*One early SIPH demonstration profect was funded where the fuel to be displaced was coal which does not usually have a supply problem. Another project was at an oll refinery which would have easy access to residual ofl for fuel. 


\section{Institutiona1 Assessment}

It is much more difficult to remain objective, to prevent personal views from being reflected in an institutional assessment and in policy recommendations than when deallng with a purely technology/hardware type assessment. Th1s institutional assessment w11l review the role of the federal government in SIPH research, development and demonstration as well as the influence of past U.S. energy policy, energy subsidies, and other legislative supports and barriers. The role of industry from the point of view of users as well as suppliers and the utility and backup system Interface problems are discussed also. As important as the technical barriers have been in preventing widespread solar energy applications, they are overshadowed by the soctal and political implications involved in the energy supply and demand issues; U.S. energy policy in the past has been influenced most strongly by political pressures and not by economic considerations. Since SIPH is very much at a disadvantage compared to energy conservation as seen from the economic assessment (yet both can displace conventional fuels), SIPH and conservation will be discussed fointly in this institutional assessment.

\section{Role of Government}

There certainly has been a trend in recent years to let or even expect government to solve our problems and provide economic security: On the other hand, especially in the energy sector, this attitude is beginning to conflict strongly with states rights, 1.e. in connection with strip mining, synfuel development, and nuclear waste disposal in Western states or natural gas production and consumption for electric generation in Texas and Louisiana. This attitude also has led to burdensome regulations. In the area of legislation, especially for environmental protection, the national interest is often in conflict with special interests or states furlsdiction, as for example in relation to the Alaska oil pipeline or coal emission standards. The most serious impediment to more efficlent energy use and solar applications in industry and elsewhere has been the lack of a definite national goal and conslstent, serious commitment, beginning with the federal government, the President and Congress, and extending on down through most state and local governments, utilities, and industries to the average consumer.

a. Past Ũ.S. Energy Policy:

Fuel consumption in the United States more than doubled between 1945 and 1970, and electricity generation increased by over 500 percent between 1945 and 1968. As early as 1952, the President's Materlals Commission appointed by Harry S. Truman predicted that America and its allies would be short of fossil fuel by 1975 (Ref. 45). The U.S. government foresaw the possibility of an energy crisis, and it chose a solution -- nuclear energy. Beginning with Eisenhower's "Atoms for Peace" plan, nuclear power was enthuslastically acclaimed as the energy source of the future. Even though many knowledgeable people urged development of solar energy in the mid 50s, government support for solar research (Including photovoltaics): was practically nil until the Arab oil embargo.

Yet despite warnings of oll supply interruptions, despite the Arab oll embargo and rapidly rising prices since, despite the threats to U.S. 
national security due to the large share of imported crude oil and the resulting inflation and crippling effect on employment and the economy, a large segment of our population (perhaps as much as half) are not convinced that there is an energy problem, and many (even in leading policymaking positions) are certain that easy solutions are fust around the cotner. The importance and benefits of energy conservation are not recognized or supported sufficlently. There exists at present no definite national energy plan with clear-cut and realistic goals taken seriously, and thus much federal and state solar legislation is ineffective and haphazardous. Supportive local legislation is, with a few exceptions around the country, practically nonexistent. Real prices for energy in the Unfted States are still too low and do neither reflect the true replacement value because of heavy subsidies nor include adequate compensation for environmental damage due to mining, use, or waste disposal. In a review of the DOE conservation and solar energy program, it is concluded that a clear vision is lacking of where we are going and how we will get there. Planning and evaluation are only assigned a very minor role with inadequate staffing. Once a definite policy has been established, it must be supported with appropriate legislation and other incentives at all levels of government, and conflicting barriers and jurisdiction must be removed (Ref, 16).

Since 1918, the federal government has spent almost 130 billion dollars for incentives to stimulate energy production, as shown in Table 25 (from Reference 46). Of this support, oil has received the largest share; support for solar energy in comparison has amounted to less than 100 million by 1976. Even though R \& D support for solar energy has increased in recent years to about one half a billion per year, the emphasis has still been heavily on the side of nuclear energy. There seems to be an imbalance between subsidies and production results. 011 subsidies have not necessarily led to increased production but to increased consumption and consequently to increased forelgn oll imports, and returns from investment in nuclear power generation have been very disappointing also. The number of completed oll wells in the U.S. dropped from 58,000 in 1956 to a low of 27,000 in 1971 (Ref. 47). If 1t is socially desirable to increase the share of solar energy in the national energy budget, then appropriate policy dectsions must be made and supported with incentive strategies and investment of federal, state, and private funds (Ref. 22).

TABLE 25

Est1mate of Cost of Incent1ves Used to. St1mulate Energy,Production, In B1111on 1976 Dollars

\begin{tabular}{|c|c|c|c|c|c|c|c|}
\hline SUBSIDY $\nabla$ ENERGY SOURCE $\downarrow$ & Nuclear & Hydro & Coal & 011 & Gas & Solar & TOTAL \\
\hline Exemption from Taxation & - & 1.7 & 3.0 & 40.5 & 11.3 & - & 56.5 \\
\hline Uräats \& Oisburjerients & - & $\cdot$ & $\cdot$ & 30.3 & 3.5 & - & 33.8 \\
\hline Trade Regulations & 1.2 & - & 2.2 & 5.6 & 0.3 & - & 9.3 \\
\hline Research \& Development & $13.3 *$ & - & 1.6 & 0.8 & - & 0.1 & 15.8 \\
\hline Market Activities & 1.7 & $12.5 *$ & - & - & - & - & 14.2 \\
\hline TOTAL & 16.2 & 14.2 & 6.8 & .77 .2 & 15.1 & 0.1 & $129.6 *$ \\
\hline Percent of Total Subsidies & $12.5 \%$ & $11 \%$ & $5 \%$ & $60 \%$ & $11.5 \%$ & $0 \%$ & $100 \%$ \\
\hline FY 1976 Subsidies & 2.4 & $5.5^{\text {t* }}$ & 0.4 & 1.2 & 0.4 & 0.1 & 10.0 \\
\hline Percent of 1975 Production & $3 \%$ & $2 \%$ & $25 \%$ & $35 \%$ & $35 \%$ & $0 \%$. & $100 \%$ \\
\hline
\end{tabular}

*Estimated average.

* Total incentives involving electricity (mostly market activitfes). 
The routine provision of energy 18 estimated subsidized at a total of 60 to 80 billion dollars per year by keeping the price of o1l, gas, coal, and nuclear power below their real costs, according to Reference 48 . It remains to be seen if the past pollcy of support for large, expensive, centralized energy developments (1.e. synfuel) w1ll continue at the expense of small-scale, communtty-based technology such as blomass and alcohol fuels. A number of recent studies have concluded that energy use over the next two decades will mainly depend on such factors as energy prices, application of different types of available technology, and energy policy decisions, with energy policy of course having a large.influence on the other two factors (Ref. 4).

\section{b. Federal Support for SIPH:}

Table 26 from Reference 17 summarizes past federal support for solar R \& D. Funding levels for 1981 and 1982 are uncertain at this time, but they are expected to be considerably lower than the 1980 level. Note that for FY 1980, solar research funding was about 7 percent of the DOE budget of approximately 12 billion dollars (including research and development for geothermal and hydro); 7 percent was allocated to conservation and 49 percent to nuclear power and weapons (Ref. 49). The federal

TABLE 26

Federal Solar Research, Development, and Demonstration Budget (Budget Authority in Militon Dollars)

\begin{tabular}{|c|c|c|}
\hline FISCAL YEAR & AMOUNT & \\
\hline 1974 & 14.8 & \\
\hline 1975 & 54.4 & · \\
\hline 1976 & 151.6 & \\
\hline 1977 & 313.1 & \\
\hline 1978 & 443.7 & \\
\hline 1979 & 554.2 & \\
\hline 1980 & 596.0 & (Ref. 49) \\
\hline 1981 & 445 & \multirow{2}{*}{$\begin{array}{l}\text { (Proposed by the Office of } \\
\text { Management \& Budget, Reagan } \\
\text { Admintstration, Ref. SO) }\end{array}$} \\
\hline 1982 & $220\}$ & \\
\hline
\end{tabular}

government has supported research and development of SIPH hardware primarily at Sandia Laboratorles (IIne-focus and central recelver systems), Jet Propulsion Laboratory (point-focus collectors), Lawrence Livermore National Laboratory, and SERI in Golden, Colorado. Under the DOE-funded MISR program (modular. Industrlal solar retrofit) at Sandia Laboratories, existing solar collector manufacturers will be invited to submit system design input which w1ll be followed by a request for proposals to industry for detailed modular designs, The selected designs will then be tested using existing hardware (parabolic troughs). One of the objectives of the program is to develop a system supplier capability (Ref. 51). Dr. LUf says in a critlque of the MISR program that Sandia personnel is understating the energy cost reductions obtalnable through MISR hardware by 1985 by at least a factor of five. SIPH will be the last solar application to come on line because it is the least economic. Government laboratory personnel have difficulties understanding the rate of return requirements of Industry (Ref. 52). 
The majority of SIPH demonstrations have been almost entirely federally funded. There are a few privately-funded smaller applications of less than $5000 \mathrm{ft}^{2}$ collector area. Since 1976, the federal government has sponsored a yearly symposium on SIPH. The early work on SIPH was funded under ERDA. Two extensive studies were made, one by Battelle Laboratorles, one by InterTechnology Corporation; both studies found a large potential for SIPH applications. The 1977 symposium's economic studies reported very high costs for SIPH systems, much too high to make them attractive to industry (Ref. 32). The 1978 symposium contained a report which reduced the SIPH potentlal by adding input from a field study. The limits found included 1imited land area and avallable "waste" heat on site, besides the usual economlc and Institutional factors (Ref. 33). The 1979 symposium gave a summary of federal SIPH funding (Ref. 21) as given in Table 27. It can be seen that large power systems in recent years have received high prlorlty and thus a larger proportion of federal funds. Because of the need and apparent potential for SIPH found in the early studies, field tests and demonstration projects were pushed too quickly, before the technology was ready and before an adequate assessment of the actual market and of alternate paths (1.e. energy conservation) was undertaken. Perhaps the major shortcoming of these fleld tests/demonstrations is that the SIPH technologies were applied without a realistic prior energy audit for the particular industrial plant and process, and without application of low-cost energy conservation, and without requiring energy management from the user. The 1980 SIPH symposium, set up to be a major source of information for potential users, was well attended by system designers and hardware manufacturers, but by at most four potential users.

TABLE 27

Sumnary of Solar Thermal Funding (M1111on Dollars)

\begin{tabular}{|lcccccc|}
\hline APPLICATION & FY 75 & FY 76 & FY 77 & FY 78 & FY 79 & FY 80 \\
\hline Large Power & - & - & 21.5 & 21.8 & 27.0 & $64.1^{\star}$ \\
Small Power & $13.2^{\star \star}$ & $26.9 \star \star$ & 20.1 & 28.1 & 28.0 & $33.5^{\star}$. \\
Advanced Technology & - & - & 7.4 & 10.2 & 14.0 & 23.4 \\
Constructton/Cap1 tal Equipment & - & 6.4 & 18.1 & 44.0 & 31.0 & - \\
\hline TOTAL & 13.2 & 33.3 & 67.1 & 104.1 & 100.0 & 121.0 \\
\hline
\end{tabular}

- Includes Construction/Capltal Equipment funding. ** ERDA

What have six years of government support achieved for SIPH? As stated in Reference 36, early solar applications should be super-successful if they are to prove the way for expanded commercialization of the technology; at this stage, one failure will offset five successes. As the site visits have shown, the fallure rate is very $h i g h$, and the wisdom of DOE in pushIng the SIPH demonstration program before the hardware development was ready could be serlously questioned. Perhaps the lack of success of this program will make industry willing to explore other solutions such as conservation and low Btu gas from garbage and other blomass. But overall, the government's support of SIPH has had little return for a considerable investment. Also, the government's expenditures in this area were not accompanied by a corresponding effort in legislation and an integrated national energy plan. 
c. Legislative Supports or Barriers:

The government's SIPH program was not accompanied by a corresponding supportive substructure in tax and other relevant legislation to encourage the application of SIPH. Industrial capltal investment into energysaving equipment, including equipment to increase productivity and reduce production costs over the long term is discouraged under present financlal conditions and tax laws, and conventional fuels, as mentioned earlier, are still heavily subsldized. No regulatory standards exist on energy consumption and efficlency in Industry. On the other hand, some regulations, especially involving cogeneration, are a deterrent to efficient energy use. Any leglslative effort must incorporate periodic review of effectiveness and a procedure for easy updating or amendment. The Nationa1 Energy Conservation Policy Act of 1978 and the Windfall Profits Tax Act of 1980 have been ineffective, because they are not specific enough for easy interpretation by industry, and they are too discriminatory and 1imited to certain investments. The conservation credits do not cover new construction, for instance. It is at present uncertain how these regulations w111 fare under the new administration.

The Energy Security Act of 1980 has the effect of diverting capital investment away from energy conservation or solar. There is presently a climate of uncertainty about future fuel price rises and fuel availability and about future government action and polfcy. Leglslation and regulation could have a stabilizing influence; however, in the past, these have consisted mainly of special tax privileges for private electric utility investments, tax privileges and low borrowing rates for public utilities, inadequate charges for federal nuclear fuel services, and spectal tax privileges for ofl and gas producers.

The Fuel Use Act of 1978 and the Public Utility Regulatory Act of 1978 have the effect of Inhibiting the application of cogeneration, since they first restrict the use of ofl and gas and secondly prohibit public utilities from owning cogenerating facilities. The rationale that led to this legislation is now no longer valid since natural gas prices are rising rapidly. Also, cogeneration is a much more efficient use of fuel oil than direct production of industrial process steam or utility-generated electricity. In addition, about half of the states have special regulations inhibiting cogeneration. DOE has been spending less than 0.1 percent of its budget on industrial cogeneration, even though perhaps as much as 20 percent could be added to existing U.S. electric generating. capacity by using available, economic sources of industrially produced steam (Ref. 16). As recently as 1950, 15 percent of U.S. electricity was cogenerated; today the share is only 4 percent. In Europe, cogeneration supplies about 29 percent of all electriclty. Cogeneration also has an advantage in time scale over SIPH, in that it could be Installed in a matter of a few months at most, once the legislative barriers are removed.

The FY 1980 appropriation for industrial energy conservation included $\$ 16.5$ million for waste energy reduction, 20.7 million for industrial process efficiency improvements, 11.2 milition for cogeneration, 9.8 million for implementation; and 2.1 million for program direction, for a total of 60 million or 0.2 percent of the DOE budget. The Office of Management and Budget is now recomending sweeping cuts for the conservation programs, amounting to 46 percent In FY 1981 and 65 percent in FY 1982 (based on the. 
proposed Carter budget). If, as DOE Secretary James B. Edwards has recently stated, the best way to achieve conservation is through proper price signals to energy users and not through regulations, subsidies or artificlal incentives (Ref. 53), then precisely these supports should end for conventional fuels, and the tax structure favoring their use should be changed rapld1y. The legislative barriers to industrial energy conservation and solar applications are conslderable and are by no means balanced by a few favorable but inadequate "solar laws".

\section{Role of Industry}

Considering the importance and extent of industry in the U.S. economy, the interest and support SIPH has recelved from industrial users and potential users of SIPH equipment has been discouraging, but in view of the SIPH demonstration results, these conservative and cautious attitudes are not surprising. Other factors such so low conventlunal energy prices and inadequate government programs (including legislation and education) certainly contribute to this attltude. Also, energy cost so far is only a small fraction of the cost of the final product. However, a pervasive attitude in U.S. Industry 18 a view to short-term profits instead of long-range goals and productivity, in contrast to Japanese industry, for instance. This lack of the long-term view or goal certainly would tend to discourage Industrial involvement in a new energy technology such as SIPH. U.S. Industry as a whole is also beset by a number of problems such as declining productivity, aging plants, high labor costs, large number of unskilled labor, high capital cost, etc., all of which act as additional barriers at the present time.

a. SIPH User/Consumer:

It is difficult to forecast future energy use by industry, since conservation efforts will depend on many factors. In general, however, it can be assumed that the present trend of reduction in energy use per average unit of product will continue. There is also a shift away from a consumeroriented economy towards an increasingly service-oriented economy. These trends can be expected to Increase due to market saturation with consumer goods, Increased demand for more durable goods, recycling of matertals, and restoration instead of replacement of older items due to raw material shortages and high prices. Many new products are not material and energy Intensive relative to cost (1.e. household computers). It can be assumed that economics will prevent SIPH acceptance by industry in the near term.

Industrial interest in energy conservation and alternate energy will largely be dependent on local supply conditions and cost of energy. At present, very little Inftlative is found in industry, either because government is percelved to be able to provide a solution to the energy problem before disaocer strikes (1.e. by substantially increased domestlc petroleum production), or because of lack of long-term planning or lack of understandIng about the seriousness of the energy problem. Unrealistic reports about government programs such as expected synfuel output, solar contributions, etc. may have added to this complacency. The reports about solar contributions do not emphasize that to achieve the projections would involve applications by almost everyone in all sectors of the U.S. economy. For example, it is rarely realized that to achleve the $2.6 \mathrm{Q}$ goal from $\mathrm{SIPH}$, an investment of $\$ 400$ billion would be required. 
On the positive side, there seems to be some interest by industry to consider using biomass as a fuel. For instance, over 150 factories in New England have switched from oil to wood. As the discussion on economics showed, almost any energy option is cheaper than SIPH at this time. Basically, productive energy use and conservation in industry can be achieved with improved housekeeping, Improvement in the manufacturing process, or in employing an alternate process (which is less energy-intensive) to achleve the same end product. While "business-asusual" may continue for a few more years, it is overly optimistic and wishful thinking to expect that the transition to a renewable energy supp1y technology/economy w1ll occur without any efforts or political changes. As stated in Reference 4, individual industrial users must realize that

1. Productive conservation takes consistent efforts by many. It is not a fancy technological fix but involves many small and perhaps a few larger changes and actions (most of them unglamorous and unspectacular). Only some of these will involve technical innovation in processes and products.

2. Productive conservation takes a serlous commitment and vigilance by top management, middle level management and plant engineers as well as by each employee.

3. Stockholders and investors cannot persist in demanding two to threeyear paybacks for investments in alternative energy, although such investment is certainly possible in first-order energy conservation.

4. For each plant, energy has to be considered with the whole picture in mind, not just plecemeal. For Instance, a relocation to a suburban area with adequate land for a solar pond may then involve so much commuting for employees (and additional shipping for the product output) that no net energy savings w111 result.

b. SIPH Manufacturers/Suppliers:

As many as 400 flat plate manufacturing companies exist, many of which are quite small and have not received federal contracts. It has been found that most of the DOE contracts have been granted to a few very large companies. The delays in federal solar legislation related to the tax rebate for active solar systems hurt the fledgling collector industry, especially smaller companies, as did some of the standards and testing (performance and efflctency) requirements for DOE-funded applications. However, flat-plate technology is sufficlently mature that it is now quite viable commerclally. A large share of the market is in the simplest application: solar pool heating. The most favorable locations and markets are California and Florida which have a favorable climate and supportive state legislation for users and manufacturers and New York and New Jersey which are areas with very high energy prices. Most of these companies are involved in prototype development. Industrial and agricultural process heat applications (sales) amount to only about 3 percent of the square footage output. The government sector, for all uses, accounted for about 3 percent of the purchases in 1978/79 (Ref. 54).

The industrial base is much smaller for concentrating collectors where only about half a dozen manufacturers have the capaclty to supply sufflclent collectors for larger SIPH applications. There are a number of smaller manufacturers fabricating DHW systems and experimental 
concentrating collectors in small quantitles (Ref. 55). It is doubtful that the concentrating collector and evacuated tube manufacturers could continue their production output without the government-funded projects. But from the experlence with the present SIPH field projects, it must be clear that industrial capacity for concentrating collector output must not be pushed artificially at this time at the cost of developing a proven, rellable product, and before a certain market demand exists for the product with proven capability to achleve the goals specifled in a national energy policy. Even if SIPH would experience a sudden, unexpected growth in sales, the present few manufacturers could supply an adequate number of collectors. At least in the near term, the lack of a large number of supplier is not a significant barrier.

\section{c. Education and Labor Requirements:}

The SIPH demonstration programs have also shown that there is a lack of understanding among users of what SIPH can be expected to do and where it is best applied. Efforts required for maintenance to assure adequate operation have also heen underestimated. An evon larger barrier to SIPH applications and even simple industrial energy conservation is the lack of qualified technical personnel to conduct energy audits and to design and install the SIPH technology. Training in industrial energy conservation and new energy systems is only just beginning in the nation's engineering and architecture schools. The resistance to improved standards even just in bullding construction by the estabitished contractors points out the inertia to change and innovation in the institutional fabric of our soclety. Advance planning to meet anticipated needs is much less successful in obtaining the necessary actions than a forced reaction to an exfsting, unavoldable crisis. It will take the actions and cooperation of many different sectors of society to achieve a general change of attitude about energy use among private as well as industrial consumers. This will be difficult to achieve as long as. special groups and interests are mistrusted and the government -- by its own conflicting actions - contributes to low credibility as to the seriousness of the energy problem.

In the short term, trained labor is not avallable to install and maintain large numbers of SIPH systems. However, the application of energy conservation should not be hampered as much by the lack of speciallzed training. Such training (i.e. to conduct energy audits) is not too difficult to obtain by engineers, and the labor required to implement energy conservation on a broad scale should help to reduce unemployment.

Most Industrial users obtaln their Information from trade fournals, not from government publications and programs (Ref. 64); thus educational programs and many examples of smaller SIPH demonstrations which would employ this established channel for information dissemination would be more successful in reaching the industrial user than the governmentsponsored symposia. It has been found that many industrial managers are quite uninformed about solar research. and its potential application to Industrial process heating. Presently, an interested industrial consumer can obtain information about SIPH from the Solar Energy Industries Assoctation, 1001 Connecticut Avenue N.W., Sulte 800, Washington, DC 20036, or from SERI, 1536 Cole Blvd., Golden, Colorado 80401 (Attention: Systems Analysis Division, telephone (303) 231-1017). 


\section{Interface with Backup Systems and Utilities}

STPH Installations in most plants are only able.to supply a fraction of the energy needed, thus they serve only to reduce demand for conventional fuels; they cannot completely replace them. The demonstration projects have pointed out a serlous problem which was not adequately considered in the designs. The SIPH system must match the requirements and operational characteristics of the industrial process to be useful. The solar energy collected benefits the industry only if neither the SIPH system nor the manufacturing process are down for maintenance. Some flexibility should be bullt into the SIPH system so that its heat can be used in alternate locations if one area is not operational. Even though technically the interface between the conventional industrial process heat system and the SIPH system has not been difficult, it has been somewhat inadequate due to this lack of flexibility. Since plant managers will change processes or operations, solar energy supplies to a plant main are more useful than if they are directed to a single process or line only. Conversely, the large downtime of the SIPH systems for maintenance has discouraged many users from making the optlmum use of the SIPH system. It has been easier to just continue operating with the conventional system than to start up and tie the SIPH system back In. This is also due to the fact that many of the SIPH systems supplied only a small fraction of the plant's energy needs. In one application where the SIPH contribution was about 30 percent, management was aware of the petroleum savings obtained each week by the system. In other applications, management did not even seem to want to know if and how well the SIPH system was operating and what the energy savings were. This indicates again that SIPH projects must be carefully custom-designed for the particular plant and must have the full support of management to be able to make optimum contributions. In one fleld demonstration which originally had a good enduse match when the process was operating during the day, management shifted operation to a night-time schedule, thus negating a large percentage of the solar benefits. With the SIPH systems financed by the government in their entirety, there was not much incentive for the industry to see to 1 t that it got the best possible return from the investment.

Industry depends on a rellable, contlnuous energy supply. Frequent downtime for maintenance is a deterrent, as is the intermittent operation of SIPH systems without storage, unless the industrial process has simflar characteristics. On the other hand, systems with storage must usually be much larger and are thus more costly. In certain locations and applications, a SIPH system mlght be useful in alleviating peak load problems for a small ut1lity. In general, SIPH systems have not experienced and are not expected to have any interface problems with utilities. However, where cogeneration is involved, a number of utility interface problems will arise and would have to be carefully considered. Reference 59: outlines one approach to removing some of these barriers. For industries with interruptible gas supplies, SIPH systems are at most only a partial answer.

There is an additional barrier that has Inhibited and w1ll most 1ikely continue to Inhibit. SIPH as well as conservation applications. If the industry expects future rationing of 1 ts fuel supplies, it does not want 
to reduce present consumption for fear of coming up short in future allocations. If SIPH systems can prove to be rellable performers, they would have a slight advantage over energy conservation under these clrcumstances, or if companies who have been able to reduce consumption over a number of years would be granted preferential treatment in future allocations, this would be in incentive to use solar systems as well as energy conservation. This agaln illustrates the need for a consistent national policy.

Utilities can be very Important in encouraging energy conservation and solar applications, elther by providing financing or with appropriate rate structures. California has plans to expand the role of public utilities. With a revised charter based on conservation and renewable resources, these utilltles will in fact be transformed into Energy Service Corporations (Ref. 60). Unless there 18 strong federal and state leadership, this transformation will not take place, or only very inconsistently. One 100 peak $\mathrm{kW}$ photovoltalc facllity funded by the federal government was to provide power for a shopping center; the PV system 1s being operated by the local utility. There was no effort made by the utility to either encourage or mandate energy conservation for the tenants in the shoppling center; nelther did the utllity (or the federal government) want to use the visitors/operations center of the PV facillty as an example of energy conservation in a commercial building.

\section{Soctal and Polftical Issues}

Soctal and political issues have been touched on throughout this assessment and are very basic to the whole question on how the energy problem will eventually be solved. It must be realized that energy is not only a local, state, and natlonal problem, but that 1 t has far-reaching, global implications, involving national security, foreign relations, etc. Certalnly political processes are involved in the decision-making of future energy policy and in allocating funds for energy development and subsidies. The energy choices also have an influence on society in terms of costs and benefits. Future energy supplies and demand are strongly influenced by the soctal and polftical declsions made in the next few years. U.S. energy pollcy so far has not been based on economfcs but on political expediency and pressures.

a. Soclal Costs and Benef1ts:

A reduction in forelgn petroleum consumption would bring about a number of social benefits such as reduced inflation, reduced unemployment, improved relations with our Western allies and Japan, and consequently increased economic security. A reduction in fossil fuel consumption in general would have such environmental benefits as reduced actd rain and reduced contaminution of the atmosphere with $\mathrm{CO}_{2}$. Petroleum supply shortages and interruptions can have serlous social consequences, can lead to factory shut-downs and perhaps even involve the U.S. In a war in the Middle East.

Increased rellance on coal of the nation and industry brings along another set of problems and social costs, from increased damage to the environment to the health hazards which coal miners are exposed to. Nuclear energy has Its problems also, and the social costs of this technology w1ll mostly 
tax future generations.: When considered on the basis of social costs alone; It seems that: the small life-style changes which would possibly be required to achleve lower demand would outwelgh the serfous consequences of increased consumption and increased domestic energy production of fossil fuels and nuclear power. Using capital for energy production at the cost of other, soclally important areas (the arts, education, improved industrial productivity) would in the end create an adverse effect on soctety and the standard of living. The utility and energy producling sector may need as much as one third of all investment capital available in the next decade, if present consumption patterns continue. On the other hand, smal1-scale, decentralized, community-based energy technology seems to counteract the trend of uninvolvement and dehumanization of soclety. Therefore, this type of approprlate technology, which can include SIPH, conservation, blomass, recycling, etc., would have a number of benefits which cannot be evaluated strictly in terms of payback and even life-cycle cost. To achleve these decisions, political action at all levels of government will be required. Diversifled appropriate technology is recognized as having many beneficial soctal consequences, among which are employment opportunities for skilled, semi-skilled and unskilled labor, Increased community coherence and pride, and Improvements in environment and the standard of living.

b. Polltical Problems:

Energy is a political 1ssue; almost dally this fact is brought out in national and international news reports. However, it has taken a considerable time for many people to realize that solar energy and its application are also a political problem, directly and indirectly. Indirectly, solar energy of course is adversely influenced by the very large subsidies which have been granted to the petroleum and nuclear industry, and by a number of tax and other laws which favor these conventional energy sources. Solar energy has also suffered from the real lack of commitment at almost all levels of government and soclety. Solar energy, compared to the other energy industries, has practically no lobby. To stand up for conservation and alternate technology has not been politically expedient for people running for office, since the implication is that these things would require change and hardship. What of course is not realized is that forced change and hardship will be inevitable if voluntary adjustments to wasteful habits are not made very soon. Political action to facil.itate solar applications is required in many different areas, 1.e. tax laws, environmental regulations, banking laws, public ut1lity regulations, etc. It will require legislation that will be unpopular or that will be a burden on consumers for a whlle, such as deregulation of natural gas prices and in general higher prices and taxes on fossil fuel consumption. Where assistance is provided for low-income groups, this assistance must not be just a handout but must be coupled to incentives for conservation and, conversely, to penalties for waste.

States where solar energy is belng applied rapidiy, such as in California, have very favorable political climates which include definite objectives, approprlate and sufficlently high tax credits and rebates, low-interest financing, and solar mandating, equipment standards, and public education. Massive public education is essentlal if energy conservation and solar technologies are to reach an effective, cumulative level in the community, state, or nation. Once soclety is beginning to move, in attitudes as well 
as actions, to buy and use lower-cost solar energy equipment and becomes familiar with this technology in everyday use in many different applications, the climate and the technological base (equipment and labor) will become more favorable for higher-technology applications such as SIPH. Loglcally, the simple, most cost-effectlve solar applications such as passive solar and solar hot water must be employed first, before funds are heavily invested in almost unproven SIPH technology.

Where the federal government is becoming involved in costly solutions of energy production and policy, such as the synfuels program and nuclear waste disposal, conflicts with states rights are inevitable.

\section{c. Future Energy Demand and Supply Cholces:}

National government pollcy as well as Industrial pollcy and decisions will be made on what is percelved to be future energy demand and the cholces and composition of the energy supply $\mathrm{mlx}$. Over the last few years, demand projectlons have been conslderably reduced by all segments, 1.e. solar advocates, the nuclear, oll and gas industry, conservationists, and DOE, as shown in Table 28. It 1s interesting to note that the lowcost approach also demands the smallest amount of energy supplied by solar. In general, none of these scenarios require technology innovation; they rely, however, on serfous conservation without much life-style changes. The policy implications of a number of low-demand scenarios will be discussed in a separate section.

TABLE 28

Profected Total U.S. Energy Consumption and Solar Contribution of a Number of Studies and Scenarios

\begin{tabular}{|c|c|c|c|c|c|}
\hline STUDY & SCENARIO & YEAR & REFERENCE & $\begin{array}{l}\text { PROJECTEO TOTAL } \\
\text { CONSUMPTION, } O^{*}\end{array}$ & $\begin{array}{l}\text { RENEWABLE/SOLAR } \\
\text { ENERGY SUPPLY, O }\end{array}$ \\
\hline Domestic Policy Review & Basel Ine & 1978 & 17 & 95 & 13 \\
\hline \multirow[t]{2}{*}{ Stanford Research Institute } & Low Uemand & 1977 & 56 & 90 & 6 \\
\hline & Scenario 11 & 1979 & & 80 & 11 \\
\hline CONAES & Scenarto A & 1979 & 57 & 72 & $3 *$ \\
\hline SERI/Sawhill & & 1980 & 18 & 60 & 12 . \\
\hline Harvard Business School & & 1979 & 4 & 106 & 21 \\
\hline Sant/Least Cost & & 1979 & 58 & 70 & $1 *$ \\
\hline
\end{tabular}

-Interpolated or rounded.

\section{Barriers to SIPH APPIications}

The listing of barriers to SIPH application in Table 2 of the Executive Summary does not attempt to rank these barriers in their importance. Looul conditions can be very lupur Lant to ranking order. In the Pacific Northwest, it is the climate together with the avallability of hydro and biomass that would be a primary barrier to SIPH. In almost any urban location, lack of avallable land and Inadequate roof area and support would inhibit SIPH use. Some of these barrlers can be overcome; but some are quite intractable and will permanently serve to reduce the demand for SIPH. The influence of these permanent barriers has not been adequately taken into consideration in earlier, optimlstic assessments. But since there are alternate, preferable, more effective and more economical ways 
of achleving either demand reductions or alternate energy supplies in industry, these barriers in the final analysis could be considered beneficlal, since they will prevent wasteful use of resources. For instance, the potential for fuel savings is so much larger through energy conservation than with SIPH applications, that this principle is emerging and beginning to be recognized even by SIPH proponents (Ref. 30). Reference 4 indicates that industrial energy use can be cut by more than one third through conservation efforts which also include cogeneration, at a total capital investment some 40 billion dollars less that that required by conventional energy production. Of the barriers in Table 2 , only the shortage of qualified labor, the lack of a national policy and commitment, subsidized conventional fuels, and unfavorable tax laws are significant barriers to energy conservation in industry, and all of these are relative$1 y$ easy to remedy.

In general, widespread solar energy use is perceived to be about 15 years away. Only those plants that are unable to obtain increased fuel supplles for new or expanded factlities would be likely to consider SIPH, or those who are otherwise constrained by environmental regulations (plant emissions) or at very remote locations. The public relations value of early application may increase some in the near term and would thus be an incentive.

Besides the legislative barriers, unfavorable tax laws, lack of national policy, subsldized conventional fuels, and high cost already discussed: earlier, other barriers to SIPH application are:

1. Industrial process heat demand can in a large number of cases be reduced much more economically by conservation than by using any type of alternate energy technology, especially SIPH (Ref. 16).

2. Industrial process heat demand can of ten be satisfied at much lower cost with a more approprlate fuel (biomass or resldual o1l, as for instance in the paper and petroleum industries), or by cogeneration.

3. SIPH applications cannot be economical in unfavorable climates and for certain end-use matches. For example, SIPH may be cost-effective In a smaller industry operating a daytime shift in the Southwest, whereas it would not be cost-effective for a larger industry operating on three shifts in New England.

4. SIPH applications (Including solar ponds) are severely constrained by land use requirements, especially in highly industrialized, urban areas (Kef. 61). This barrier has been severely underestimated in earlier SIPH assessments.

5. SIPH applications are discouraged by the high cost and unavallability of capital. An additional impediment is the requirement by industry for payback periods of less than five years (less than three years in many cases) for energy investments. Fuel costs can be written off against profits whereas alternate energy installations are treated as capital investments which have to be depreciated over several years.

6. Widespread SIPH applications are hampered by the technology itself. Manufacturing output for the hardware is limited, and operating experience to date for many systems has been dismal. Additional $R \& D$ is required to obtain a rellable product and to increase efficiency.

7. Design, installation, and maintenance expertise is presently lacking. Some Industries are unsultable for SIPH applications because they emit pollutants which serlously decrease the efficlency of concentrating 
collectors, unless frequent cleaning occurs (which is a prohibitive requirement costwise).

8. Lack of confidence in the technology, lack of operating and maintenance experience, lack of information about the capabilities of solar energy, as well as uncertainties as to backup fuel supplies and choices are very real hindrances to SIPH application by industrial energy users.

9. Energy conservation, cogeneration, and biomass fuels can come on line much more quickly than a SIPH factlity which is handicapped by much longer time requirements for design, construction, and checkout.

\section{POLICY IMPLICATIONS}

\section{A. Domestic Energy Policy}

Table 29 summarizes the domestic policy implications for the industrial sector of a number of low demand energy future studies. It is not surprising that they unanimously recommend a rise in energy prices to reflect the replacement cost of ofl and natural gas and to provide a consistent signal to industry and management for making energy conservation and capital investment decisions. Federal and state governments must first of all set a firm goal and policy to curb demand and encourage conservation, and this decision must then be supported with appropriate legislation and regulations, especially in the area of utility regulation. Prohibitive regulations agalnst cogeneration must be removed. Financially, tax reform; tax credits and other capital investment Incentives will be required, although the actual amounts will depend on other pressures upon the federal and state budgets. Most striking in the recommendations is the redirection of federally-sponsored $R \& D$ towards more practical, short-term, low-cost technology.

Without a vision of what is to be achieved and the kind of soclal goals that should be incorporated, pollcy will only be plecemeal, incomplete, or inconsistent. Without a definite, comprehensive, realistic policy, no effective program planning and commitment can occur, and consequently little approprlate action and few desired results will follow, as has happened under the current National Energy Plan. Figure 27 shows this process in flow diagram form, 1llustrated with an example that also indicates assignment of responsibility for each step. (Other internally consistent examples could be used equally well instead.)

\section{B. International Implications}

Except for the extensive SIPH demonstration program in the U.S., there seems to be very little activity internationally in solar thermal industrial process heat. India, for example, is heavily involved in every aspect of small-scale solar energy applications, including research, demonstration and commercialization. Large thermal systems such as the $10 \mathrm{~kW}$ solar power plant at the Indian Institute of Technology in Madras and the one in Bhavnagar are being done jointly with forelgn governments (Germany and Switzerland, respectively). These are for research and development only. The general att1tude towards SIPH is that even with considerable improvement in the technology and substantial reduction in 
TABLE 29

Policy Implications for the Industrial Sector

\begin{tabular}{|c|c|c|c|c|}
\hline STUDY & PRICING & REGULATION & TAXES AND LOANS & OTHER \\
\hline $\begin{array}{l}\text { CONAES, Ref. } 57 \\
\text { lquoted from } \\
\text { Ref. } 65\end{array}$ & $\begin{array}{l}\text { Quadrupling of energy prices by } \\
2025 \text {. Include capital cost of cen- } \\
\text { tral station cogeneration in elec- } \\
\text { tric utility rate base. Rafise } \\
\text { utility's buy-back price for sur- } \\
\text { plus cogenerated electricity and } \\
\text { lower price of supplenental onwer. }\end{array}$ & $\begin{array}{l}\text { Require electric transmission lines } \\
\text { to serve as cormon carriers. Give } \\
\text { partial relief from environmental } \\
\text { regulations for coal fueled co- } \\
\text { generation plants. Reduce threats } \\
\text { of regulatory control from cogener- } \\
\text { ators. Require cogeneration for all } \\
\text { new large steam and power plants. }\end{array}$ & $\begin{array}{l}\text { Investment tax credits and } \\
\text { accelerated depreciation for co- } \\
\text { generation. Loan guarantees for } \\
\text { district heat. }\end{array}$ & $\begin{array}{l}\text { R\&D for advanced technologies, low } \\
\text { temperature (less than } 300^{\circ} \mathrm{F} \text { ) } \\
\text { heat, and storage devices for re- } \\
\text { newable energy resources. Give } \\
\text { priority to cogeneration plants for } \\
\text { natural or synthetic gas purchases. }\end{array}$ \\
\hline $\begin{array}{l}\text { Jant, Ref. } 58 \\
\text { lquoted from } \\
\text { Ref. } 65\end{array}$ & Deregulate energy prices. & $\begin{array}{l}\text { El iminate mandatory conversion to } \\
\text { coal. }\end{array}$ & $\begin{array}{l}\text { Eliminate tax incentives and sub- } \\
\text { sidies which distort ways to improve } \\
\text { energy productivity. }\end{array}$ & $\begin{array}{l}\text { Increase funds for developing } \\
\text { energy efficient technologtes. }\end{array}$ \\
\hline $\begin{array}{l}\text { jtanford, Ref. } 63 \\
\text { lquotied from } \\
\text { Zef. } 65\end{array}$ & $\begin{array}{l}\text { Deregulate fossil fuel prices. Re- } \\
\text { vise utility rate structure; imple- } \\
\text { ment flat rates for electric power } \\
\text { for cogeneration; establish zquit- } \\
\text { able utility buy-back price for sur- } \\
\text { plus cogenerated energy. }\end{array}$ & $\begin{array}{l}\text { Relax sulphur dioxide emission } \\
\text { standards. Exempt cogeneration } \\
\text { facilities (operating in parallel } \\
\text { with, but not selling to, utilities) } \\
\text { from F.E.R.C. and P.U.C. juris- } \\
\text { diction. }\end{array}$ & $\begin{array}{l}30 \% \text { inves tment tax credit for co- } \\
\text { generation. 12-year depreciation } \\
\text { option. Tax exemptions for indus- } \\
\text { trial cogeneration plants using oil } \\
\text { and gas. Investment tax credit for } \\
\text { conservation and solar energy in- } \\
\text { vestments. Loan guarantees for } \\
\text { cogeneration. Low interest loans } \\
\text { for solar energy and conservation } \\
\text { technologies. }\end{array}$ & $\begin{array}{l}\text { High priority allocation of ofl and } \\
\text { gas for cogeneration. Utility. } \\
\text { financing or ownership of industrial } \\
\text { energy equipment. }\end{array}$ \\
\hline $\begin{array}{l}\text { Harvard Business } \\
\text { jchool, Ref. } 4\end{array}$ & $\begin{array}{l}\text { Prices for conventional fuel must } \\
\text { rise. Prices for nuclear and coal- } \\
\text { generated electricity must include } \\
\text { external cost to environment. }\end{array}$ & $\begin{array}{l}\text { Utilities need to give preferred } \\
\text { rates to solar users. Utilities } \\
\text { must be encouraged to enter the } \\
\text { energy conservation field. }\end{array}$ & $\begin{array}{l}\text { Conventional fuel use should be } \\
\text { taxed. Solar equipment should re- } \\
\text { ceive } 55-60 \% \text { tax credits. }\end{array}$ & $\begin{array}{l}\text { 10-year intensive government-funded } \\
\text { R\&D in new solar technology, } \\
\text { followed by conmercialization. }\end{array}$ \\
\hline $\begin{array}{l}\text { SERI/Sawhill, } \\
\text { Ref. } 18\end{array}$ & Increase conventional energy prices. & $\begin{array}{l}\text { Encourage cogeneration and wind } \\
\text { electric generation; establish } \\
\text { goal-supporting regulations, remove } \\
\text { barriers. }\end{array}$ & $\begin{array}{l}\text { Tax reform which includes tax } \\
\text { credits, low-interest loans and } \\
\text { accelerated depreciation to raise } \\
\text { investment in conservation \& solar. }\end{array}$ & $\begin{array}{l}\text { Blomass as industrial fuel must be } \\
\text { developed. Government R\&D support, } \\
\text { increased public information and } \\
\text { education. }\end{array}$ \\
\hline $\begin{array}{l}\text { Jummary remarks } \\
\text { from Ref. } 65\end{array}$ & $\begin{array}{l}\text { Utflity price structure must en- } \\
\text { courage cogeneration. Energy prices } \\
\text { must rise to reflect replacement } \\
\text { cost of oil and natural gas. }\end{array}$ & $\begin{array}{l}\text { Remove environmental and other re- } \\
\text { gulations which are hampering co- } \\
\text { generation. }\end{array}$ & $\begin{array}{l}\text { Tax incent fves for cogeneration. } \\
\text { Low-interest loans for investments } \\
\text { in solar and conservation. }\end{array}$ & $\begin{array}{l}\text { Implement energy housekeeping, waste } \\
\text { heat recovery with 3-5 year payback. } \\
\text { R\&D to improve motor efficiency. } \\
\text { Recycle materials. Production of } \\
\text { more durable goods. Some solar R8D. }\end{array}$ \\
\hline Doctor: Ref. 52 & $\begin{array}{l}\text { Stop subsidies to producers and } \\
\text { consuners of nuclear, oil, cas } \\
\text { and coal energy. }\end{array}$ & $\begin{array}{l}\text { Mandate cost-ef fective energy con- } \\
\text { servation. Utility rate structure } \\
\text { must encourage conservation and } \\
\text { cogeneration; credits given for } \\
\text { solar and conservation, disallowed } \\
\text { for energy-consuming equipment. } \\
\text { Require utilities to purchase power } \\
\text { from. Industry and homeowners using } \\
\text { al ternate energy. resources. }\end{array}$ & $\begin{array}{l}\text { Tax credits for solar and conserva- } \\
\text { tion, rebates for low-income con- } \\
\text { sumers. Low-cost loans for alter- } \\
\text { nate energy to bus inesses and } \\
\text { industry. Utilities may provide } \\
\text { financing. }\end{array}$ & $\begin{array}{l}\text { State energy plans are important. } \\
\text { Public education and certifica- } \\
\text { tion of solar equipment must re- } \\
\text { ceive support. Priority must be } \\
\text { given to projects involving smail } \\
\text { bus inesses, low-cost applications, } \\
\text { and community-based programs. }\end{array}$ \\
\hline
\end{tabular}




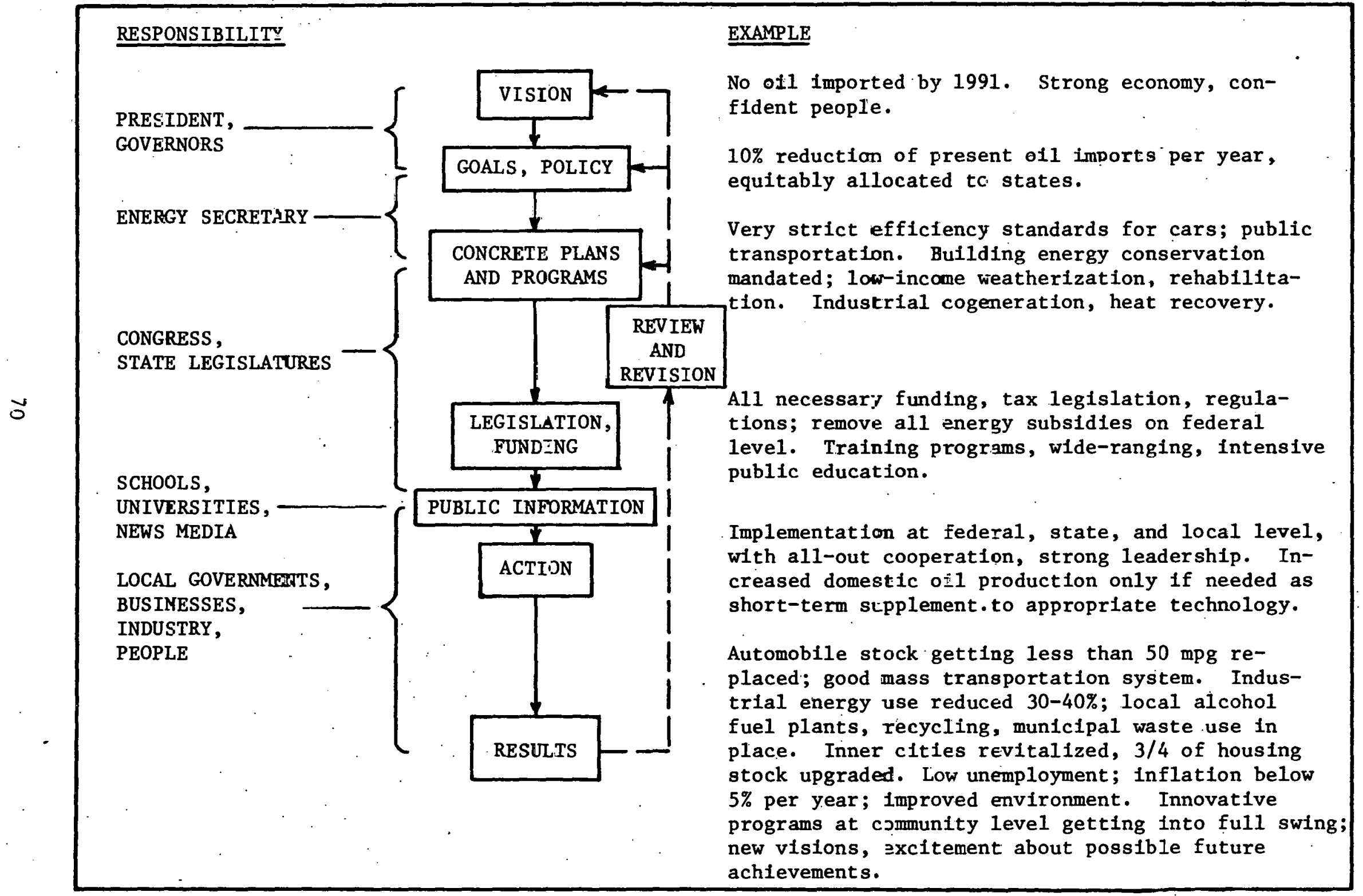

Plan for Development and Implementation of National Energy Policy, with Example of Results 
cost, SIPH is not. 11kely to be a major source of energy in the foreseeable future. Energy conservation in industry is being stressed, although implementation of these measures and a clear program to achleve energy conservation in industry are clearly missing.

In Australia, two sizeable fleld projects are worth noting, a demonstration unft at White Cliff, New South Wales, which uses parabolic dishes to generate temperatures up to $550^{\circ} \mathrm{C}$ for generation of $25 \mathrm{~kW}$ of power. This project is under criticism because of its high cost (in excess of U.S. $\$ 1,000,000)$ and technical problems. A1so, a development unit of $10 \mathrm{~kW}$ electrical conversion from solar thermal energy is being jointly carried out near Perth with Germany. Both are government-funded profects. Industrial energy conservation 18 being stressed (as in other countries), but again no clear program to achleve this has been established. One successful manufacturer in Western Australia is Solarhart which only sells thermosyphon solar water heaters; it has an international distributor network and receives orders of over 200 untts per day (several million square feet per year).

Much discussion and paper studies have been done in countries such as Brazil concerning the use of solar industrlal process heat (Ref. 66). With the exception of some very small projects, there are no immediate plans in Australla or Brazll for slgnificant SIPH applications. Most studies are in the category of Identification of SIPH potentials as was done in the U.S. by Intertech several years ago (Ref. 14). Other countries such as Switzerland, Germany, and France are more interested in exporting the solar technology for SIPH rather than in using it in thelr own countrles, because they have unfavorable climatic conditions and very crowded situations for their. industries. Abundant opportunities are observed in industries in many countries for energy use efficlency improvement, consumption reduction and energy management. ThIs is an area where cost-effective U.S. technology could be exported, and these opportunities abound in developing as well as industrialized nations.

It is often sald that developing countrles are also those that have abundant sumshine. But both rich and poor developing countries must choose their technologies to make use of this resource most carefully. Poor developing nations are $11 k e 1 y$ to choose labor-intensive appropriate technologles for thelr needs, whereas rich developing countrles lean towards high technology manned with imported personnel. It would be more beneficlal for developed and developing nations if fuller use were made of renewable resources rather than of technologies that are economically unsound. Thus the high-technology systems being tested by the Germans in countries such as Egypt or Indla may remain $R \& D$ projects for a long time before technical, cultural and economlc barrlers will be lowered sufficiently to admit their indroduction into the marketplace. The major emphasis for the near term in renewables in many countrles (Indla, China, Australia, New Zealand, Brazil, Colombia, Costa Rfca, etc.) is still on more development of hydro and blomass (including wastes). Wind power is receiving its share of attention in many of these countries also. Energy waste in industry is prevalent in almost every country, and energy conservation must be coupled with extensive educational programs in order to be successful. The U.S. can only effectively support these programs if they have been proven at home. 
Despite government expenditures of over 100 million per year since FY 1978 for solar thermal development and demonstration, there has only been one totally commerclal SIPH sale of signiflcance. Many technical problems as well as soci-economic barriers still exist. In light of these, a contribution from SIPH of at most 0.25 Q by the year 2000 may be expected with approprlate government support. However, much greater benefits can be achieved through a varlety of energy conservation measures. Economically, there is a much greater incentive for industry to Invest in energy conservation, if concrete information for specific Industries were available. Heat recovery systems, for example, are quite reliable and have payback perfods consistent with industry requirements. Industry traditionally will not invest in high-risk, unfamiliar systems outside their product 1ine. The SIPH demonstration program has fafled to attract capital investments for solar energy applications in industry. The almost 100 percent government-financed SIPH demonstrations are viewed as "expensive toys". Further demonstrations with even larger systems at this time are nelther likely to achleve cost reductions nor Increase user confidence, because the hardware ts not yet ready and sufficlently developed to be able to withstand troublefree operation over a ten to twenty-year span. On the other hand, development of alternate technology to provide Industrial process heat such as efficient process steam plants using municipal wastes as fuel may result in exportable-products of interest to many industrlalized as well as developing countries and would thus doubly benefit the United States and Its international balance of payments.

Specifically, the following recommendations have resulted from this assessment:

1. DOE or some other agency deslgnated by the President must develop a consistent but realistic energy plan which includes policy planning as well as periodic evaluation. The emphasis must be on the most cost-effective methods for the near term, yet the plan must grow out of an imaginative concept or vision of how energy use is related to the entire fabric of soclety, locally, nationally, and globally.

2. Legislation must be consistent in supporting this policy at all levels of government, and conflicting signals (1.e. low fossil fuel prices and subsidies for conventional energy supplies) must be removed.

3. Federal funds must be directed towards $R \& D$ support for efficiency improvements in industry, Including waste heat recovery and cogeneration. Such emerging tcchnologles as thermoelectric/thermal and photovoltaic/thermal cogeneration which produce both electriclty and low-grade heat and whlch promise to be very durable and rellable should recelve careful attention. Tax credits for private $R \& D$ have been very successful in Japan.

4. The use of blomass and munlclpal wastes as industrial fuels should be encouraged in the near term, because these can make a major impact on the displacement of scarce fossil fuels. However, other sources of 
alternate energy, such as wind and small-scale hydro, should be considered and supported where appropriate.

5. Government (federal, state) involvement in SIPH should continue in the area of materials and components testing and research, in information and education, and in providing tax and financial incentives. The govemment should also assist in the formulation of standards to help industry achieve confidence in solar thermal equipment. State and local governments should consider mandating energy conservation standards.

6. SIPH demonstration systems in the field that have not operated for a year or only intermittently should be scrapped and funding discontinued. These systems are an embarrassment and will not help improve the image of solar. Good operating systems should be optimized, if necessary with some additional funding. Projects presently under construction should be reviewed with the aim of achieving better operational results and efficiencies by quality improvement in the hardware and by incorporating cost-effective methods of conservation in the entire manufacturing process.

7. There is very little need at present for additional SIPH market and projection studies. Data from the upgraded SIPH demonstration sites should be collected and evaluated for a period of not less than five years, and the results must be made known to the public. There is a need for more candid reporting of negative results in order that past mistakes will not be repeated in future projects.

The following programs and actions should receive priority in the specified time frame:

$\underline{1982-1983}$

Energy conservation; education about appropriate technology, support to sma11 businesses for diversified energy $R \& D$ and to community-based projects; state energy policy planning; legislative support structure.

$\underline{1984-1987}$

Continuation of strong emphasis on conservation, with mandating if necessary; wide application of lower-cost solar technologies, waste recycling, cogeneration. Training of techniçal and semi-skilled work force; attention to quality in appropriate technology hardware.

$\underline{1988-1991}$

Review of progress; assistance to developing countries with domestical$1 y$ proven systems; reduction of government involvement and overhead. 


\section{REFERENCES}

1 Peter DeLeon, B.L. Jackson, R.F. McNown, G.J. Mahrenholz, The Potential Displacement of Petroleum Imports by Solar Energy Technologies, SERI/TR-352-504, May 1980.

2 Assistant Secretary for Conservation and Solar Energy, Energy Conservation Program Summary Document, FY 1981, DOE, February 1980 .

3 Edward Lumsdalne, Montka Lumsdalne, Energy Production and Consumption Patterns and Impact of Solar Energy in New Mexico - A History and Forecast to the Year 2000, Report $\# 14$, New Mexico Energy Institute, New Mexico State UnIversity, Las Cruces, New Mexico 88003, Feb. 1978.

4 Robert Stobaugh, Dantel Yergin, eds., Energy Future, Report of the Energy Project at the Harvard Business School, Random House, New York, 1979.

5 Assistant Secretary for Conservation and Solar Energy, Solar Energy Program Summary Document, FY 1981, DOE/LS-0050, August 1980.

b Energy Information Administration, Month1y Energy Review, DOE/EIA 0035/01, 21 January 1980.

7. M.H. Chlogioj1, Industrial Energy Conservation, Marcel Dekker, Inc., New York, 1979.

8. K. Kreider, M.B. McNeil, eds., Waste Heat Management Gulde, National Bureau of Standards Handbook 121, Federal Energy Administration, Washington, DC, 1977.

9. W.T. Snyder, W.A. Miller, F. Schmidt-Bleek, How to Cut the Energy Budget in Business and Industry, Environment Center and Center for Industrial Services, Untversity of Tennessee, Knoxville, TN 37916, February 1974.

10. Harold W. Henry et a1.; Energy Management Theory and Practice, Marcel Dekker, Inc., New York, 1980.

11. J.F. Bodine, V. Marshall, Industrlal Energy Use Data Book, Oak Ridge Associated Universitles, Oak Ridge, TN 37830, ORAU, 1980.

12. Industrial Sector Technology Use Model; Industrial Energy Use in the United States, 1974-2000, Energy and Environmental Analysis, Inc., $\mathrm{DOE} / \mathrm{FE} / 2344-1,1978$.

13. R.B. Kidman, R.J. Barrett, D.R. Koenig, Energy Flow Patterns for 1975, Los Alamos Scientific Laboratory, June 1977.

14. InterTechnology Corporation, Analysis of the Economic Potential of Solar Thermal Energy to Provide Industrial Process Heat, 00028-1, Warrenton, VA, 1977.

15. Putting the Sun to Work in Industry, SERI/SP-34-175. 
16. Conservation and Solar Energy Programs of the Department of Energy A Crit1que, Doc. OTA-E-120; Congress of the U.S., Office of Technology Assessment.

17. Domestic Pollcy Review of Solar Energy, TID-22834, Feb. 1979, National Technical Information Service, U.S. Dept. of Commerce, 5285 Port Royal Road, Springfield, VA 22161.

18. Kar1 Gawe11, SERI Solar/Conservation Study, Part II (Sawhi11 Report), as summarized in Solar Energy Intelligence Report, Vo1. 6, No. 37, 15 September 1980 .

19. G.J. D'Alessio, R.P. Blaunstein, Preliminary Definition and Characteristics of a Solar IPH Technology and Manufacturing Plant for the Year 2000, DOE/EV-0100, September 1980.

20. Acurex Corporation, Energy for Industry, AED-14, May 1980.

21. Solar Industrial Process Heat Conference Proceedings, SERI/TP-333-429, Oakland, Californ1a, 31 October - 2 November 1979.

22. B.J. Graham, A Survey and Evaluation of Current Design of Evacuated Collectors, DOE AL) $-5350-1,30$ September 1979.

23. N.E. Dudley, Sumary Report: Concentrating Solar Collector Test Results, Collector Module Test Facility, Sandia Laboratory, SAND 78-0815, May 1978.

24. Solar Production of Intermediate Temperature Process Heat, Phase 1Design, Final Report, DOE/CS/30311-TI, August 1980.

25. L.P. Leibowitz, T.M. Liu, "Parabolic Dish Solar Collectors for Industrial Process Heat Applications," SIPH Pre-Conference Proceedings, Houston, Texas, December 1980, pp. 1-7.

26. T.S. Jayadev, Michael Edesess, Solar Ponds, SERI/TR-731-587, April 1980.

27. ISES, Sunworld, Vo1. 4, No. 5, Pergamon Press, New York, 1980, pp. 171 -173 .

28. James F. Banas, Technology Assessment: Line-Focus Concentrators, 792221, Sandia Laboratories, Albuquerque, NM 87185.

29. Solar Times, Vo1. 3, No. 3, March 1981, p. 13.

30. Charles F. Kutscher, Roger L. Davenport, Primary Operational Results of the Low-Temperature Solar Industrial Process. Heat Field Tests, SERI/TR 632-385, June 1980.

31. Ken Brown, The Use of Solar Energy to Produce Process Heat for Industry, SERI/TP-731-621, Apr11..1980.

32. Solar Industrial Process Heat Sympostum Proceedings, 19-20 September 1977, DOE 非61-00.0-00109-3, Conf. 770966. 
33. Solar Industrial Process Heat Conference Proceedings, Vol. I, 18-20 October 1978, SERI/TP-49-065, Conf. 781015.

34. Jack C. Hyde, The Characterization and Assessment of Selected Solar Thermal Energy Systems for Residential and Process Heat Applications, DOE/EV-0102, September 1980.

35. Solar Industrial Process Heat Workshop Proceedings, 28-29 June, 1976, ERDA Conf. 760655, published August 1976, avallable from National. Technical Information Service.

36. Solar Industrial Pre-Conference Proceedings, 16-19 December 1980, Houston, Texas, SERI/CP-632-951.

37. J.B. Trice, C.L. Romig,. T. Duff, Solar Production of Low-Pressure Steam for Processing Orange Julce, presented at the SIPH Conference In Houston, Texas, 16-19 December 1980 .

38. "Cost Analyses of Ten Solar Industrial Process Heat Engineering Field Tests," Mueller Associates, Inc., Baltimore, MD; presented at the SIPH Conference in Houston, Texas, 16-19 December 1980.

39. P.L. Hofmann, "A Survey of the Current Solar Collector Product Literature," Sun II, Proceedings of the ISES Silver Jubllee Congress, Vol. 3, pp. 2006-2009.

40. W.C. Dickinson, Annual Avallable Insolation for Solar Systems: Economic Implications for Industrial Process Heat, Lawrence Livermore Laboratory, Livermore, California 94550.

41. R. Fazzolare, G. Mignon, L. Campoy, F. Luttmann, A Guldebook for Solar Process Heat Applications, Arizona Solar Energy Commission, $1700 \mathrm{~W}$. Washington, Phoenix, AZ 85007, January 1981.

42. W.C. Dickinson, K.C. Brown, Economlc Analysis of Solar Industrial Process Heat Systems: A Methodology to Determine Annual Required Revenue and Internal Rate of Return, UCRL-52814, 17 August 1979.

43. W.C. Dickinson, The Role of Financing in the Marketability of Capital Intensive Solar Technologies for Industry, Lawrence Livermore Laboratory, Livermore, California 94550, 1981.

44. H.F. Schuler, D.F. Rost, G. Amedur1, Public Law Number 59.1 Taxes Solar Energy at up to 46 Percent, presented at the 1979 AS/ISES Conference, Atlanta, Georgia, 28 May - 1. June 1979.

45. Ken Butt1, John Perlin, A Golden Thread, Cheshire Books, Palo Alto, CA, 1980.

46. B.W. Cone et al., An Analysis of Federal Incentives Used to Stimulate Energy Production, Executive Summary PNL-2410, March 1978, Battelle Pacific Northwest Laboratorles, Richland, WA 99352 (rev. Feb. 1980).

47. S.S. Penner, L. Icerman, Energy, Vol. I, 2nd ed., Addison-Wesley, Reading, Mass., 1981. 
48. R.D. Doctor, Alternative Energy Development Tug of War, presented at the Denver Conference on Renewable Energy Resources; Denver, Colorado, 4 October 1980 (California Energy Commission).

49. Excerpt from The Wolf Guarding the Door, Institute for Ecological Policles, 8208 Christopher Street, Falrfax VA 22031, as quoted in the Sunpaper; NMSEA Bulletin, Vo1. 5, No. 12, December 1980.

50. Solar Times, Vo1. 3, No. 3, March 1981, pp. 1-2.

51. MISR - Modular Industrial Solar Retrofit Multiyear Project Plan, DOE Albuquerque Operations Offlce, P.0. Box 5400, NM 87185, Sept. 1980.

52. Solar Times, Vo1. 3, No. 1, January 1981.

53. Solar Age, Vol. 6, No. 3, March 1981, p. 12.

54. Solar Collector Manufacturing Activity, January through June 1979, DOE/EIA-0174, 1979.

55. Solar Products Directory, Solar Age, Vo1. 5, No. 4, Apr11 1980.

56. John S. Reuyl et a1., Solar Energy In Amerlca's Future, A Preliminary Assessment, 2nd ed., March 1977, DSE-11512, available from Superintendent of Documents, U.S. Government Printing Office, Washington, DC 20402, Stock No. 060-000-00078-6.

57. Report to the Committee on Nuclear and Alternate Energy Systems (CONAES), Alternate Energy Demand Futures to 2010, NatIonal Academy of Sciences, 1979.

58. Roger Sant, The Least-Cost Energy Strategy: Minimizing Consumer Costs Through Competition, Carnegie Mellon Institute, 1979.

59. Tennessee Valley Authority, TVA Act of 1933 and Public Ut1lity Regulatory Policies Act of 1978; Proposed Pollcy on Dispersed Power Production and Interim Program and Guidelines for Implementation, TVA, 8120-01, 840 Power Bldg., Market Street, Chattanooga, TN 37401.

60. R.D. Doctor, Financing the Renewable Resource Future: A New Role for the Utilities and State Government, presented before the National Conference of State Legislators, New York, NY, 9 July 1980 (California Energy Commission).

61. A.B. Casamajor, R.L. Wood, Potentlal Industrial Process Heat Applications for Solar Energy at Temperature $<170^{\circ} \mathrm{C}$ : Fleld Study, presented at the Annual Meeting of AS/ISES, Denver, Colorado, August 1978.

62. R.D. Doctor, The Solar Domestic Pollcy Review: A Task Undone, January 1979, California Energy Commission.

63. E235 A1ternate Energy Futures Study Team, A1ternative Energy Futures: An Assessment of U.S. Options to 2025, Stanford University, 1979. 
6.4. Vickre Mylison, Solar Industrial Process Heat Survey of Industrial Appilications and Attitudes, Draft Report, SERI/TR-733-1015, October 1980.

65. Low Energy Futures for the United States, DOE/PE-0020, June 1980.

66. A. Viefra de Carvalho Jr., A. de Faro Orlando, and D. Magnoli, "Solar Energy for Steam Generation in Brasi1," INTERCIENCIA, Vo1. 4, No. 3, May/June 1979.

\section{ACKNOWLEDGEMENT}

I am indebted to the plant engineers and managers at the thirteen SIPH demonstration sites visited for kindly taking the time to show me around and answering my many questions. Ms. Marilyn A. Chase has prepared the drawings and graphs. Most of al1, I want to acknowledge the help of my wife, Monika Lumsdalne, in sumartzing material and assembling this report from sheaves of notes. She has also edited and typed the final manuscript, for which I dearly thank her. 